Western University

Scholarship@Western

Digitized Theses

Digitized Special Collections

1988

\title{
Management Accounting And The Adoption Of Flexible Automation
}

Anton Peter Dimnik

Follow this and additional works at: https://ir.lib.uwo.ca/digitizedtheses

\section{Recommended Citation}

Dimnik, Anton Peter, "Management Accounting And The Adoption Of Flexible Automation" (1988). Digitized Theses. 1726.

https://ir.lib.uwo.ca/digitizedtheses/1726

This Dissertation is brought to you for free and open access by the Digitized Special Collections at Scholarship@Western. It has been accepted for inclusion in Digitized Theses by an authorized administrator of Scholarship@Western. For more information, please contact tadam@uwo.ca,

wlswadmin@uwo.ca. 


\section{NOTICE}

\begin{abstract}
AVIS
La quailte de selle microtorme defend grandement de la qualite de la these soumise au miciotlmage Nous a:ons lout tampour assurer une qualite superteure de reproduc. tion.

Sill manque des pages veulle: communiquer avec runiversile qui a confere le grade

- La qualite dimpression de certanes pages peut laisser a desirer surtout siles pages originales ont ele daciylogra-

- phiees a laide dun ruban use ou si luniversite nous a lail parvenir une photocopie de qualite inferieure

Les documents qui font deja lobjel diun drolt dauteup laricles de revue lests publies etc. ne sor: pas microlilmes

La reproduction. meme pantelle de cella micróorme est soumise a la Lor canadienr.: sur te dice dialteur sic 1970 < $C 30$
\end{abstract}

Reproduction in full or in part of this microtorm is governed by the Canadian Copyright Act. A S C $1970,2 \mathrm{C} \cdot 30$ Previously copyrighted materials (journal articles, pub-
ished tests, etc) are not filmed

$\because$


MANAGEMENT aCCOUNTING AND. THE aDOPTION OF FLEXIBLE AUTÓHATION

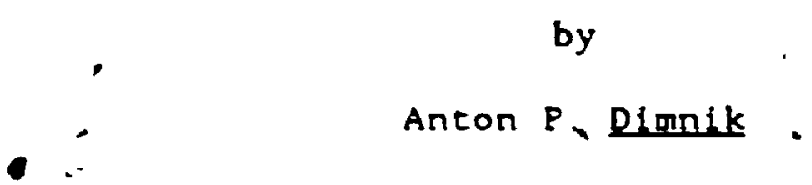

School of Business Administration

Submitted in partial fulfillment of the requirements for the degree of Doctor of Philosophy

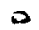

Faculty of Graduate Studies The UnIversity of Western Ontario London, Ontario July 1288

(c) Anton P. Dimnrk 1988 
Figure 1.1 Flexible Autonation Rade-offs.

Figure 1.2 Direct and Indirect Effects of MACS on Adoption

Figute 3.1 Process of Selecting a Research Sample

Figure 6.1 Role of MaCs in Justifying Investments

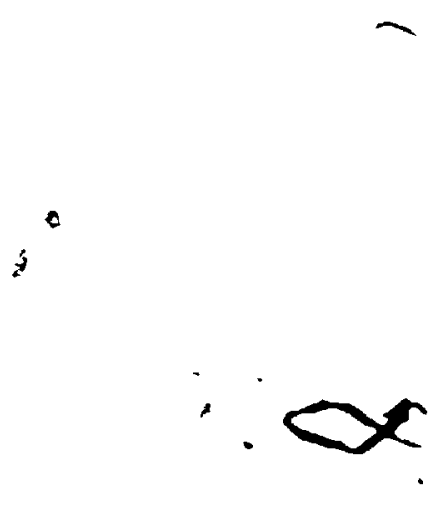





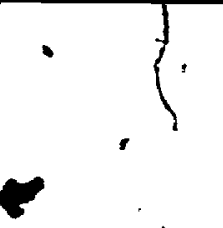

\section{ACKNOWLEDGEMENTS}

It is not often that we are given a chance to publicily thank those who have helped us, so I will take full advantage of this opportunity.

I thank the Faculey of Administratson at the University of Regina, especially Dean tutchings for first suggesting doctoral studies, and Prafessors Hópkins, Mclaren and Beshara for encouraging me and preparing ae for graduate'school.

I thank the faculty and staff of the School of Administration at the University of Western Ontario: Professor Ne[l Hill who first incerested ge in accounting and autonacion: 'PhD Program Chalrman, Blair Litcle, and PhD Administrator. Phyllis jackson, who were always there when I needed thear, Professor Adrian Ryans who taugtit we research metbodology: Professor Nick Fry who taught me cast writing and sowéthing about strategy: Don. Barclay who taught we PLS: "Chris Higgins who gave me wy first chance to do research: and the support staff, especially the people who work in the library, in the print shop, and in the case roon, who ware always kind to me.

- One of the best decisions I ever mat was to study with the Macs area group at Western. I have never met atpore supportive group of people I thank Ross Archibald for his leadership; Claude Lanfranconi for hiss good counsel, enthusíasm and encouragement; Rich Mimick for his

- Eriendliness; and Rick Robertson and Howard Teal, for showing the way.

I a also grateful to Jdlien. Bilodeau, ay partner in the PhD program.

This thesis would not have been possible without the assistance of General Motors'Director of Purchasing. Bill Eagen, and Supplier Quality Control Manger: Alan Dickson: I am especially grateful for Álan's support. As well. I thank. the General Kotors personnel and the 32 plant managers. Who stole a few precious hours from their extremely busy schedules to particlpate in this study.

-

I. appreclace the tremendous support of wy family: Anton and Ivanka Dimnik, Martha and Ralph Ottenbreit, and Debbie and Sidney Braak.

I thank Randy Kudar, my thes Is supervlsog. Ten years ago, in the acknowledgements to his thesis, Randy promised that someday he would repay the kindness of all the people who helped him, by offering the same. cooperation and isupport to his PhD students. Randy has kept that promise. Someday, 1 wil. remey Randy's kindness by hielping someone
else. through the doctoral experience.

Finally, I thank Judith, Kristy and Corrine. Kristy and Corrine have been walting for this announcement for half their lives: Girls, the theols is Finished! Thanks for your patlence and your love. And Judith, thank you. I owe you evegything, so it 1s to you that I dedicate chis thesls. 
- 2 TABLE OF CONTENTS

CERT TFICATE OF EXAMINATION

ABSTRAOT!

ii

ACKNOWLEDGEMENTS

TABLE OF CONTERTS

LIST OF TABLES

vili

LIST OF FIGURES

CHAPTER ONE

Section I: Research Que'stions

Section II: Relevancy of Research

A. Contribution to Management Practice. . _ . . . . . . 3

B. Contiribution to Accounting and Accounting Research . . 5

8

Section III: Importance of Flexible Automation".

A. Flexibility of Process. Product and Capacity

B. Flexible Automation as Competitive Weapon

C. Flexible Automation as Change Agent

D. Summary of Flexible Automation Benef
Section IV: Adoptian of Flexible Automation

Section V: Definitidns, Assumptons and Boundarfes

A.Management Accounting and Control Systems (MACS)

B. Plant Managers

C.Flexiblè Automation

Section VI: Hypotheses

A. Model A: Main' Hypotheses

B. Model B:. Additional Hypotheses

C.Assessing Threats to the Validity of the Results

Sectior VII: Outline of Remalnịng Chapters

CHAPTER TWO . . . . . . . . . . . . . . . . . . . . . . 31

Section I: The Normative Literature . . . . . . . . . . . . 31

A. The Management Llcerature. . . . : . . . . . . . . . . 34

B. Production/Englneering Literature . . . . . . . . . . . . 38

1. Subjective dvervlews/Guldelines . . . . . . . . . . . 39

- 2. Quentleative. Techniques/Analysis Methodologles. 40

C. Accounting Llteraqure. . . . . . . . . . . . . . . . . 42

Section II: Empfrical Accounting Research . . . . . . . . . . 45

Section III: Chapter Sumary. . . . . . . . . . , . . . . . . 49

$\cdot 3$ 
CHAPTER THREE

Section I: Methodology . . . . . . . . . . . . . . . . . . . . 51

A. Choosing Empirical Research . . . . . . . . . . . . . . 51

B. Choosing a Population. . . . . . . . . . . . . . . . . . . 52

C. Choosing a Sample of Planes and Managers

1. "A Prior" Measures of Adoption and Plant

Performance

2. Goal Congruence in the GM Supplier Network. . . . 59

3. Measures of Adoption Variability and Response Bias 63

D. Choosing a Data Collection Method . . . . . . . . . . . 67

Section II: Surveying Suppliers . . . . . . . . . . . . . . . . . . . 68

A. Tests of Self-Selection Bias

B. Data Collection Procedures

Section III: The Four Supplier Groups

A. Group 1 - Metal Stampers

B. Group 2 - Plastic Molders and Finishers

C. Group 3 - Rubber Parts Manufacturers

D. Group 4 - Decorative and Functional Die Casters. . 76

E. Opportunities for Automation . . . . . . . . . . $\quad 77$

CHAPTER. FOUR

Section I: The Mail Questionnaire

79

A. EMFEVL (EMphasis on accounting For Evaluation)

84

B. TMHOR (TiMe HORizon of accounting system)

84.

1

$* \quad$ D.DIFQUN (DIFficulty in QUaNtifying benefits of automation)

92

E. DECENT (DECENTralization) ${ }^{3}$. . . . . . . . . . . . . . 100

F.ADOP (ADOPtion of flexible automation) . . . . . . . . 106

G. Other variables. . . . . . . . . . . . . . . . * 108

Sedition II: Face-to-Face Interviews and Plant Visits. . . . 109

A. Collecting and Coding the Interview Data . . . . . . 109

B. Face-to-face Interview Variables . . . . . . . . . . . . . 109

Section III: Chapter Summary . . . . . . . . . . . . . . . . . 111

$i$

$i$

.. $\quad$ L $\bullet$ 
ChAPTER FIVE. . . . . . . . . . . . . . . . . . . . . . . 112

Section I: Statistical Methods... . . . . . . . . . . . . . . 112

Section II: Sampling Issues . . . . . . . . . . . . . . . . . . . 114

A.Plant Sampling Issues......... . . . . . 115

B. Respondent Characteristics . . . , , . , , . . 118

Section III: Measurenent Issues . . . . . . . . . . . . . . . 122

A.Measures of MACS and Decentralizatian. . 122

1.Reliabllity . . . . . . . . . . . . . . . . . 122

2. Construct Varidity . . . . . . . . 128

B.Measures of Adoption . . . . . . . . . . . . . . 132

C. Sumary Statistics......... . . 135

Section IV: Tests of Model A..................... 137

A. Main Hypotheses. . . . . . . . . . . 137

B. Respondent Rank and Model A. . . . . . . 142

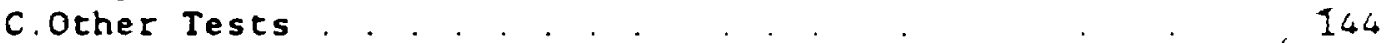

Section V: Tests of Model B . . . . . . . . . . . . . . . ( 145

A Maín Hypocheses. . . . . . . . . . . . 145

B. Respondent Rank and Model B. . . . . . . . . . . 151

Section VI: Chapter Summary . . . . . . . . . . 154

CHAPTER SIX . . . . . . . . . . . . . . . . . . . . 155

Section I: Intorpreting the Statistical Results . . . . 155

A. H1: EMrEVL not related to ADOP. . . . . . . . 156

B. H2: TMHOR2M is related to ADOP. . . . . 157

C. H2: TMHOR3F not related to ADOP . . . . . . . . . . 159

D. H3: EMFJST not related to ABOP. . . . . . . . . . 161

1. Different Types of Investments. . . . . . . . . 161

2. Semantic Problems with EMFJSTIM . . . . . . . . . 164

E. H4: DIFQUN not-related to ADOP........ . . 165

F. H5 \& H6: DECENT does not affect HI \& H3 results . . . 167

Section II: Future Research . . . . . . . . . . . . . . . . . 168

Section III: Assumptions. . . . . . . . . . . . . . . . . . . 171

Section IV: Recommendations and Corclusion....... . . . 175

A. Recomendations for Top Management . . . . . . . . . . 177

B. The Need for Fleld Research . . . . . . . . . . . . . . 178

C. Thesis Sumary . . . . . . . . . . . . . . . . . . . 180

BIBLIOGRAPHY . . . . . . . . . . . . . . . . . . . . . . . .

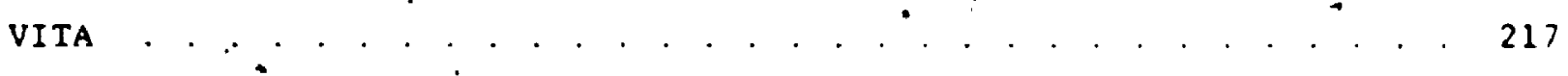

vi1 
Table 1.1

Table 1.2

Iable 1.3

Table 2.1

Table 2.2

Table 2.3

Table 3.1

Table 3.2

Iable 3.3

Tabie 34

Table 3.5

Table 41

Table 4.2

Table 4.3

Table 4.4

Table 4.5

Table 4.6 .

Table 4.7

Table 4.8

Table 4.9

Table 4.10

Table 4.11

Table 4.12 Other Items in the Mall Questionnaire.

Table 5.1 Flexible Automation Adoption Rates.

Table 5.2 Frequencies of Hierarchical Variables.

lable 5.3

Table 5.4

Table 5.5

Table 5.6

Table 5.7

Table 5.8

Table 5.9

Table 5.10

Table 5.11

Table 5.12

Model A Constructs

Use of Investment Appraisal Metho'ds.

Flexible Automation Adoption Rates

Items in Survey of GMC Personnel

GMC Survey Resules.

Participation by Group

Data Collection Process.

Main Variables in Models $A$ and $B$

EMFEVLIM

EXFEVI2M

EMFEVI3M

TMHORIM and TMHOR2M.

TMHOR 3M

EMFJSTIM

DI FQUNIM

DECENTIM

DECENT2M

Rellability Tests.

Convergent and Discriminant Validity
NC Machines as Percent of Machine Tool Consumption

International Comparison of Robot Usage.

Coding of Normative Literature... . . . . . . . 33

54

in Adopters

64

$66^{\circ}$

70

71

82

87

89

91

94

96

98

99

104

105

107

108

117

120

124

131

Convergent Validity of Adoption Measures. . . . . $\quad 133$

Tests of Model A Hypotheses.

Correlations Between Time Horizon Items and.Adoption. . 141

Model A (Controlling for MANPJS) . . . . . . . . . . . . 143

147

150

151

153 
Figure 1.1 Flexible Autonation-2ade-offs.

Ffgure 1.2 Direct and Indirect Effects of MaCs on Adoption.

Figure 3.1 Process of Selecting Research Sample

Figure,6.1 Role of MaCs in Justifying Investments

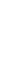


LIST OF APPENDICES

APPENDIX A: LITERATURE REVIEW CODING

182

APPENDIX B: INVITATIONS SENT TO GMO SUPPLIERS . . .

188

APPENDIX C: MAIL QUESTIONNAIRE DOCUMENTS . . . . . . . . . . . . . . . . 192

APPENDIX D: INTERVIEW PROTOCOL . . . . . . . . . . . . . . . . . . 195

APPENDIX E: INTERVIEW COOING SHEET . . . . . . . . . . . 203
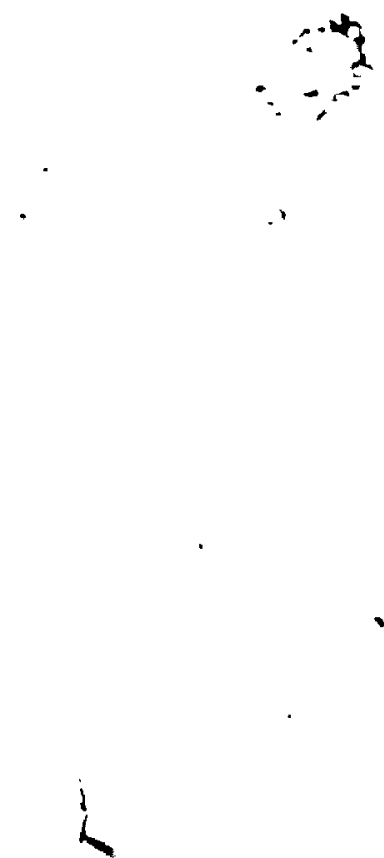

$\vdots$

8

$\because+\cdots$

$-$

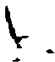

$j$

$x$ 
The author of this thesis has granted The University of Western Ontario a non-exclusive license to reproduce and distribute copies of this thesis to users of Western Libraries. Copyright remains with the author.

Electronic theses and dissertations available in The University of Western Ontario's institutional repository (Scholarship@Western) are solely for the purpose of private study and research. They may not be copied or reproduced, except as permitted by copyright laws, without written authority of the copyright owner. Any commercial use or publication is strictly prohibited.

The original copyright license attesting to these terms and signed by the author of this thesis may be found in the original print version of the thesis, held by Western Libraries.

The thesis approval page signed by the examining committee may also be found in the original print version of the thesis held in Western Libraries.

Please contact Western Libraries for further information:

E-mail: libadmin@uwo.ca

Telephone: (519) 661-2111 Ext. 84796

Web site: http://www.lib.uwo.ca/ 


\section{CHAPTER ONE}

Chapter One is divided into seven sections. 'Section I states the research questions addressed by this research ahd section II discusses the potential conertbutions of the research The next two sections look at advantages of flexible automation and at evidence that canada is lagging in the adoption of advanced technologies section $V$ presents some key definitions, assumptions and boundaries of the study and Section VI Iists the actuad hypotheses tested by the study The final section outlines the remaining chapters of the thes:s.

\section{Section Li Research Questions}

Critics have charged that obsolescent managerial accounting and control systems are a bartier to the adoption of flexible automation in North American manufacturing firms. Flexible automation includes robotics. and other computer controlled, reprogrammable machinery and equipment.

Traditional anagerial accounting and control systems (MACS) are said to be retarding the adoption of flexible automation in two ways:

1. The use of accouriting measures to eviluate performance forces managers to strlve for short-term results and ignore the long-terd welfare of their firag. Because the adoption of flexible automation. may depress short-tern accounting results, managers who are evaluated by these results will avold adopting new technologies. 
2 Many of the benefits of flexible autoration are difficule to quantify in financial teras Capital budgeting systens that emphasize financial criteria for justifying investments are thus biased against flexible automation.

'A number of changes in the characteristics and uses of Macs hive been proposed to make these systems more supportive of flexible automation Four of the most common prescriptions are

1 Top management should place less emphasis on accounting measures of performance in the $\vdots$ evaluation of lower level managers

21 Top management should ensure that accounting measures properly reflect the long-term objectives of the firom

3 Top management should place:less emphasis on financial criteria in the justification of investments in flexible automation.

4. Top management should make it essier to justify

- Investments in flexible automation by considering some of the less easily quantified benefits of new technologies.

The validity of these prescriptions has been unsubstantlated by. empiricat esearch. This dissertation thus attempts to answer four specific questions

1. Is the use of accounting measures to evaluate performance related to the adoption of flexiblo automation?

2. Are the tae horizons laplicit in maCS related to the adoption of flexible automation?

3. Is the use of financlal crlterla in evaluating capital budgeting proposals related to the pdoption of Elexible automation?

4. Are difficulties in quantifying flexible sutomation benefits related to the adoption of flexible automation? 
The research was conducted in 32 General Motors of Canada part suppliers. Adoption was aessured at the level of the manufacturing plant. Self-administered questionnalres and face-to-face interviews of plant managers were used to assess the MACS of each plant and each plant's adoption of flexible autodation, Statistical tests were then cionducted to see if the characteristics and uses of Macs were related to adoption

\section{Section II' Relevency of Research}

\section{FI... Contribution to Management Practice}

The results of this research will be of interest to top managers who want to promote the adoption of flexible automation in their firms. Two recent surveys demonstrate that Canadian managers are concerned that MACS are retarding investment in new technology. The Thompson. Lightstone survey of 376 Ontario manufacturing managers found cost fustification ranked second, right after problems in finding quafified people to operate new equipment, as a barrier to innovation (Ontario Centre for Advanced Manufacturing 1986). In the second survey,. conducted by the Canadian Institute of Metalworklng in confunction with the National Association of Accountants (U..S.). Canadlan managers were asked to list the obstaclea that stand in the way of Iaproving

I As Hill d Dianik (1986) point out, it is Important that MaCs be - fine-tuned to support the mount and type of Investment deemed - necessary by top managenent. 
Investaent decisions in advanced anufacturing technologies. Twentytwo percent of the respondents cfted capital budget linications, 192 clted orientation cowards short-ters results. and $15 y$ cited the inaccuracy or unreliability of cost/benefit forecasts Another question in the sane survey, asked respondents to list the obstaclos to improving performance measurement systems. The most frequenty mentioned obstacles were emphasis of management on short-term financial results, inappropriate performance weasurement concepts, and conservative accounting and financial practices (Canadian CAD/CAY Council 1987 )

In Chapter Two. I will present a wide-rangling literature that contends that managers consider MaCS as a barrier to adoption It is not clear from reading the literature reviewed in Chapter Two, or from examining the two studies cited above, whether managerial concerns about MACS and adoption are grounded in fact. It is one thing to say that managers think MACS is a batrier to adoption and another thing to show that certain characteristics and uses of MACS are irideed related to the adoption of flexible automation. One cannot even be sure that managers really believe that MACS are a problem in sdoption. MACS argiso often critlcized in the medla that wat passes as managent oplnion max simply reflect what managers are reading. 
II. B. Contribution to Accounting and Accounting Re'search

Cowenting on the rcle of Macs in fostering short-term tide horizons, -

Merchathe \& Bruns (1986) write:

In the first half of this decade, managers have been accused of selfish actions omd managenent ayopla. Managers allegediy overenphasize short decision horizons. In most cases, these allerations have been based on the presumed effects of performance measurement and evaluation systens, which create situations where managers take actions that make them look good in the short term but ale not good for shareholders, long-term corporate heastn, or the national economy (p.56, Emphasis Added).

The concise Oxferd Dictionary defines "allegation" as an "assertion 1 (especially one not proved)," and "presumed" as "assumed, taken for granted " Research on the topic of PACS and adoption of flexible automation is needed because criticisms of Macs and proposed changes to MACS are based on perceptlons that MACS are retarding adoption and on assumptiens that the suggested changes would promate adoption.

In discussing accounting research, Ijfri (1967) states:

Unless we can show that the different flgures:(or, more precisely, different patterns of figures) lead to different decisions under given set of conditions, there is no polnt arguing the werlts or demerlts of alternative accounting aethods (p. 150).

There is an onus on accounting researchers to show that characteristics and uses of MACS make a difference in the adoption of advanced technologies and to prove the efficacy of any proposed changes to those systens. 
Kaplan (1983) has argued that accounting researchers wust face.the. challenge of dévising new tnternal accounting pystews that w11 be supportive" of the adoption and iaplementation of advanced - sanufacturing technologies. One of his suggestions is to.

Identify U.S. firos that have been using non-financial performance measures for senior and/or plant wanageis. and) compare the performance of these firms (as meas say, by stock price returns, market share, or praduct innovation) relative to those of a comparable set of fich using mostly financial measures of performance ( $p .702$ ).

The intent and wethodology of this research are congruent with kaplan's suggestion. The study compares the MACS of Canadian plants which have c c $c^{4}$ achieved various levels of adoption pf flexible-qutomation. - Given the focus on plants and plant managers. it ls logical that performance be defined in terms of process innovation and that MACS include both performance measurement and capital budgeting systems.

The goals of this thesis are also consisterit with a number of other proposed and ongoing research projects. In Canada, the Canadian CAD/CAM Council (1987) has recommended that the federal government fund a two-year. $\$ 200,000$ project, to "develop new aethods of calculating the financial justification of Computer Integrated Manufacturing by recognizing modern competitive trends in manufacturing."

In the United States, the National Association of Ac-ountants (NAA) has 
undertaken chree studies of Macs and advanced technology. ${ }^{2}$ Two of the projects are co-sponsored by CAM-I (Conputer Aided ManufacturingInternational). The joint NAA/CAM-I studies have been applauded by wricers In various management publicaclons (Ashburn 1986. Barrie 1986. Port 1987).

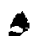

Elsewhere, INSEAD (European Insticute of Business Administration), has initiated a study of "Performance Indicators in the Technology" Function." Initial cesults of the INSEAD profect confirm the need for more study of the role of macs in the adoption and implementation of advanced technologies (Troberg 1986).

It is evident there is a need to study the relationship between MACS and adoption. I will now present some reasons why the adoption of flextble automation is an issue of concexn. I will begin by discussing several aspects of manufacturing flexibility and then go on to describe how flexible automation may serve as a competitive weapon and a catalyst for organizational change. Finally, I will show that Canada lags its competitors In adopting flexible automation. 


\section{Section III importance of Elextble Automation}

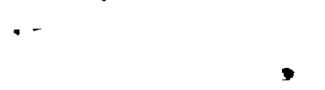

III.A.Flexiblity of Process. Product and Capacity

Flexible automation cechnologies share a comion feature: their operation is controlled by cbmputer. Within certain limits, changes in. product or manufacturing process can be accomplished by chahging the computer sof ware that controls the machinery This software

- flexibilicy may be compared with the flexibility of production technologies cradicionaliy used in job shop and mass production situations .

\section{$\downarrow$}

Through the. Intensive use of labour, job shops can produce a varlety of parts inisuall volumes. Within limits. changes in process can be accomplished by changes in human software (1e. retraining). However even minor process or product changes may require expensive and tme consuming hardware changes in a traditional, automated mass production system Tayres \& Miller 1983).

Besides having process and product flexibllity, computer controlled equipuent is flexible in another sense. Flexible aútomation equipment may be purchased in less "lumpy" amounts than' hard autoaation equipaent. In other words. flexible automarion capacity can be r adjusted In smaller incrobents than can hard automation capacity. And. because a varlety of parts can be,produced with the sane equlpment. 
flexible autonation bay be better utilized than hazd autonation

Increaental capacity adfustments and maximum utflization of achinery are particularly relevant in the context of the sall Canadian arket (HeGourey 198े)

\section{.}

The flexibility of computer operated machinery does not come without - costs. Figure 1.1 shows how flexible automation, applied to batch ' volumes, trades off the advantages and disadvantages of job shop and

mass production.

Figura 1.1 may be sumarize

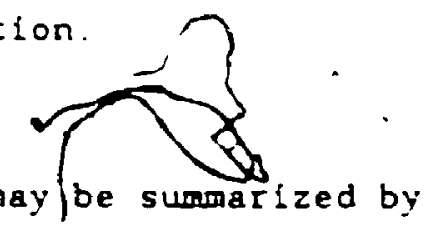

controlled machinés for batch production realizes advantages of scale over job shop production and advantages of scope over mass production (Jelinek \& Goldhar 1983, Jelinek \& Goldhar 1984).

\section{III.B.Flexible Automation as Competitive Weapon}

- Since the early 1980's, North American managers have been exhortéd to adopt flexible automation In order to survive global competition. The Canadian Manufacturers' Assoclation (1982) states:

A 'flrm's most important competitor in the 1980's may not be the company on the other s ide of town, but firm located actoss the border or perhaps across the ocean. To be conpetitfve now means to be internationally competitive ( $p .7$ ). 


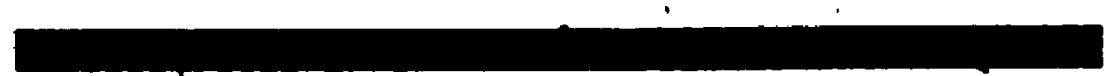

Fi gure 1.1

Flexible Autonation Trade-Offs

High Labour Cost Per Unit

High Precision

High Flexibility

Job Shop

(Manual Labour)

Low Labour Cost Pet. Unit

Low Precision

Low. Flexibility

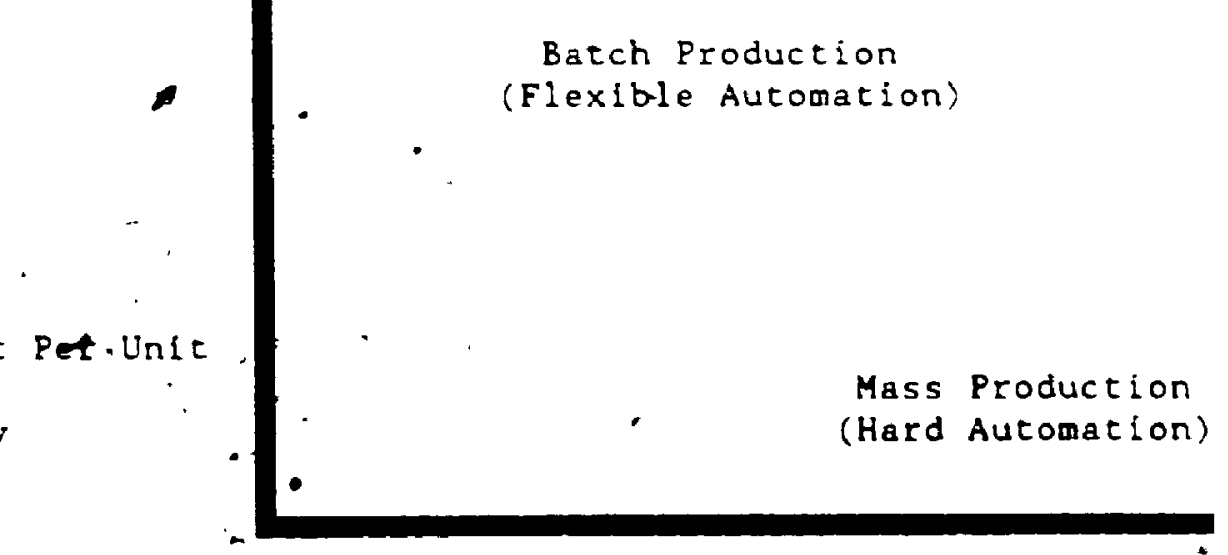

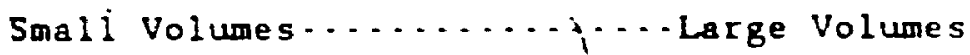
Cuscon Made.................. Standardized Low Inventory Costs...High Inventory Coots

Adapeed from:

Jellnek \&oldhar (1983)

Ayres o Miller (1983)

Jalkumar (1984)

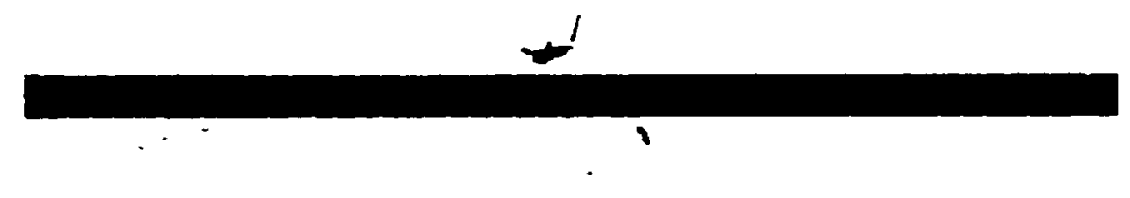

$\mathbf{\Delta}$

- North Amerlcan manufacturers aro belng challenged by forelgn flrms with low cost labour, by forelgn ficms with a capability to respond quickly to Innovation and by forelgn fras which produce high value goods.

Flexible automation is seen the key to meeting these three competitive threats. 
$=$

V.A.Manzgement Accounting and Control Systems (MACS).

In this study, the tem "Management Accounting and Control Systems"

(MACS), refers to performance measurement and reward systems and.

capltal budgeting systems. A performance measurement and reward system bay include budgets and accounting measures of performance

Capital budgeting systems play a direct role in the adoption of. flexible automation. A capital budgeting system provides a means of sifting through alternative proposals to select those that best meet top management objectives and it provides clues to project inftiators and supporters about the strategic frection in which top managenent may wish to take the firm (Hill Dimnik 1986).

Performance measurembite and reward sysths play a lass obvious role in adoption:

5 . An often oyerlooked Internal characteristic which can be manipulated to improve the capital budgeting process is the firm's reward structure.. The path and concurret.t rewards along the path that proposal follows from its origlnator in operations to its approval by top corporate executives can have a great deal of influence on (1) the projects selected (2) the quality of the cash flow and project lives estimates and ( 3 ) on the post audit' Information collected and utilized (Haka 1987. p. 36).

-

Commenting on Bower's (1970) work, Caves (1980) writes:

Bower holds that a company's top management approves or refects profects but has 11ttle direce influence on how they get defined or on whlch ones are pusiied through thf fIrm' lower levels of declolion-aking tó becone clalmants for top-executle. approval... Top managenent cannot keep the character and compostion of the projects that riso for thelr approval from beling colored by-eructural context. Howdver. top mandgenent 
low labour cost forelgn manufacturers. Instead. North American manufacturers should take advantage of a well-trained and educated workforce and concentrate on the production of high-value goods. High-

value goods ire products of high quallty, made-to-order products and products that embody the newest technologies. Using flexible automation is the most efficient way of prqducing high-value products (Reich 1983, Ayres \& Miller 1983).

II C. Flexible Automation as Change Agent

The adoption of even a single computer-controlled.maciline may precipitate change in what the firm does and huw it does it. The adoption of flexible automation may be a catalyst for closer cooperation between managers of various departments, for a rationalization of organizational structure and procedures (eg. just. in-time), and for greater awareness of product quality (Ayres o Miller 1983. Arbose 1985, Regan 1985, Skinner 1986). In short. Flexible automation may make North American firms more like their European and Japanese counterparts who are sald to be better organized for global competition. Thus, flexible automation may not only help North American flrms compensate for organizational shortcomings (Boltz 1995). but the new technology may change the organizations themselves. 
III.D.Sumary of Flexible Automation Benefits

Champions of advanced technologies maintain that North American

manufacturers must adopt new manufacturing technologies in order to

survive global competition. As Honeywell Ine CEO, Rod Bilodeau once

warned:

Make no mistake about it, we're in an economic war and if we, as a country, don't get off our bufts and improve our competiciveness, we're going to los this war and pay a heavier price than we could ever imagine. (Canadian Manufacturers' Association 1982 , p. 1).

Fo put it even more succinctly. North Amerlean manufacturers must automate, emigrate or evaporate.

\section{Section IV: Adoption of Flexible Autionation in Canada}

Given the apparent advantages of flexible automation, one wight expect there to be widespread adoption of these technologies. However, this

is not the case:

Canada's persistent $1 \mathrm{ag}$ in the introduction and use of computer-bașed technologies is an urgent national problem of wajor proportions. The diffusion of process technologies is too slow. The capltal investment needed for the introduction af advanced equlpment is also lagging serlously. Wtthout that spending. process automation just cannot take place (Economic Coulncll of Canada T987, p. 6 ).

In the next few pages I wlll present evidence that Canadian firms lag behind firms in other countries in the adoption of flexible automation

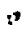


technologies. ${ }^{3}$ I will begin with some statistics on the adoption of computer numerlcal control machines (CNC machines).

As of 1983. Canada had 3500 numerlcal control machines compared to Japan's more than 300,000. Adjusting for the fact that Canada's manufacturing sector is one-seventh the size of Japan's, Japan still has a fifteen to one advantage in numerically controlled tools (Ontario Ministry of Industry. Trade and Techrology 1985). Furthermore, as shown in Table 1.1, the gap between Canada and Japan may be increasing only 4.47 of the new machine tools purchased in Canada in 1983 were. numerically controlled compared to $381 x$ of Japanese installations. ${ }^{4}$ in

3 A technology by technology comparlşon between Canadlan and international adoption rates is presented In Litvak warner (1987).

4 Though numerlcal control (NC) aachines need not be operated by computer, they are consldered reprogramatte. In any case, many of the references cited in thls thesis do not make a distinction between NC and CNC (computer numerlcal coinliol) wachines. 


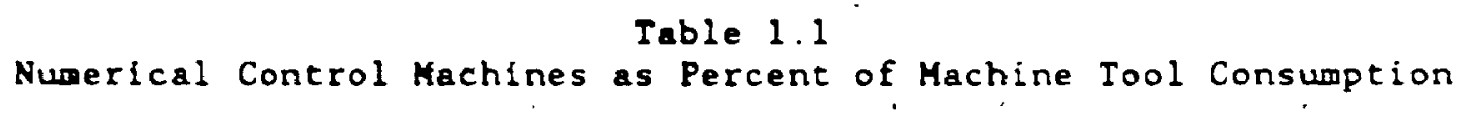

$\begin{array}{llr} & \text { Japan } & 38.1 \% \\ \text { Unifed Scaces } & 12.9 \% \\ \text { United Kingdod } & 8.1 \% \\ \text { Canada } & 4.47\end{array}$

Note Percentages calculated on a unit basis

(Ontario Ministry of Industry. Trade and Technology 1985, p. 9)

$\cdot$

A simflar pattern emerges when Canadian usage of robots is compared to other nations. Table 1.2 shows that as of January 1, 1984, there were only 3.7 robots for every 10,000 workers in Canada compared to 32.1 in Japan, 20.2 in Sweden and 7.2 in West Germany.

Finalły, looking at automated inspection and autometed materials handling iechnologies, about $60 z$ of Japanese manufactuling firms, so employing 100 or tore workers were using these microelectronic technologies by 1982 . Simllar levels of adoption were not reached in Canada until 1985 (Economic Counc1l of Canada 1987). 
Table 1.2

International Comparison of Robot Usage

$<$

Country

Robots in Use

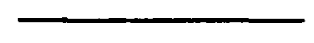

Japan

Sweden

West Germany

Czechos lovakia

France

Belgium

U.S.

Italy

Canada

United kingdom

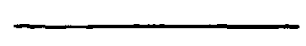

(Ọtario Ministry of Industry, Trade and Technology 1985, P IR-8)

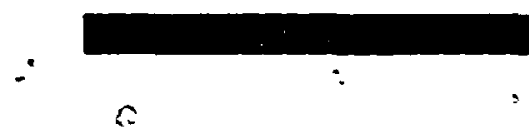

Section $v$ : Definftions. Assumptions and Boundaries .

Having established that Canadian firms lag in the adoption of flexible automation and that this lag is undesirable. I will now return to a discussion of the research. This section establishes a framework for the study of the mats-adoption relationship by presenting formal definfelons of three key cerms: MaCS, plant managers and flexible automation. In defining these terms i will circumscribe the boundarles of the research and will explicltly state some agjor assumptions After tills is done, I wll present the research hypotheses. 
V.A.Management Accounting and Control Systems (MACS).

In this squdy, the terw "Management Accounting and Control systems"

(MACS), refers to performance measurement and reward systems and.

capital budgeting systems. A performance measurement and reward system may include budgets and accounting measures of perforance

Capltal budgeting systems play a difect role in the adoption of: flexible automation. A capital budgeting system provides a means of sifting through alternative proposals to select those that best meet top management objactives and it provides clues to project inftiators and supporters about the strategic firection in which top management may wish to take the firm (Hill \& Dimnik 1986).

Performance measuremine and reward sysths play a less obvious role in adoption:

5. An often oyerlooked internal characteristic which can be manipulated to improve the capital budgeting process is the fira's reward structure. . The path and concurrer.t rewards along the path that a proposal follows from its originator in operations to its approval by top corporate executives can have a great deal of influence on (1) the projects selected (2) the quality of the cash flow and profect lives estimates and ( 3 ) on the post audit'information collected and utilized (Haka 1987. P. 36).

$\cdot \cdot$

Comenting on Bower's (1970) work, Caves (1980) writes:

Bower holds that a company's top managenent approves or refects profects but has 1 ittle direct influence on how they get defined or on whlch ones are pusised through the flrm's lower levels of decision-making tó becouc clalmants for top-executi.e. approval... Top management cannot keep the character and compostion of the projects that rles for thelr approval from belng colored by-eructural context. Howdver, top andgenent 
can Influence that structural context by wans of the organization chart. . and the measureaent and reward systen it eaploys (p. 76)

Inplicit in Haka's and Bower's views of the adoption pracess is the Idea of controb. Capital budgeting and performance messurement and reward systems may be thought of as management controls systems (Itam: 1977). Looklng at adoption frad management control perspective requires the identiflcation of controllers and controlled (Hofstede i 1968. Tannenbaum 1968) There are two obvious cho:ces of controller/controlled dyad. firm owners/top management or top management/lower level ranagement A study of the owner/top managemen: dyad would have to assume an open sistem perspective and examine some very broad social is sues

$c$

It's conventional wisdom now to say Canadian and American companies try so hard to look good today that they devote too litele tlase and brainpower to how they'll do tomorrow There may be some question. however, about the root of the problem Maybe ' 1 ts less the fault of BIg Business than of North Amerlcans in general / Do we ali-workers. consumers. Investorn. and governments.-pres too hard to get le now (McArthur 1986. P FI)?

This thesis will not examine relationships between ftro owners and top managedent nor address the broad social issues that such a perspectlve entalls. The scudy is testricted to the Internal systems of firas. nind focuses on cop anagement/lower level anagement control dyads

6 The doasin of the research ls narroved in a second way. The sicudy is resericted to the role of accounting thedeblen Adoption or purchane of new cechnolggy ary be viewed as ine first phase of the Insrovation 


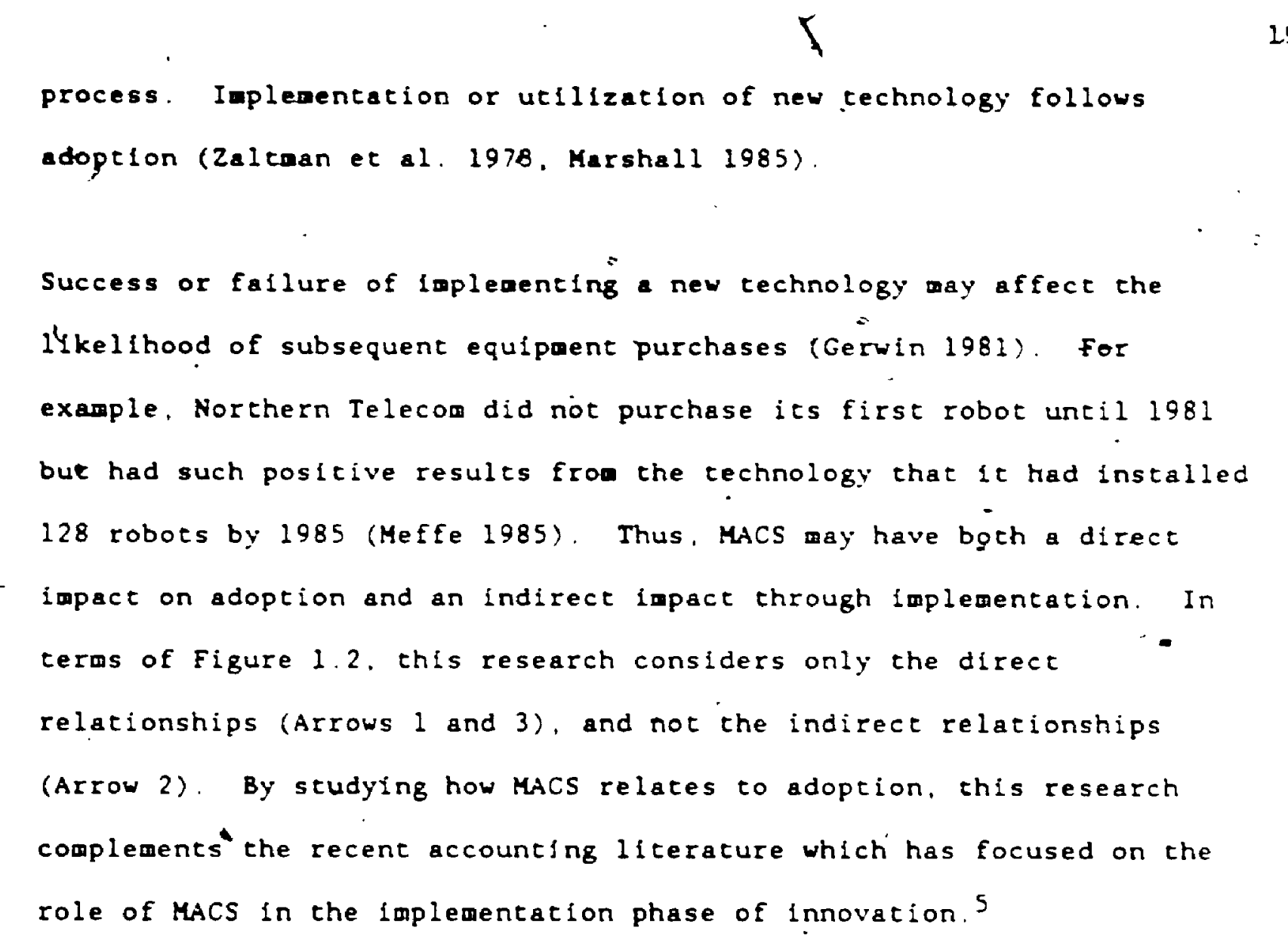



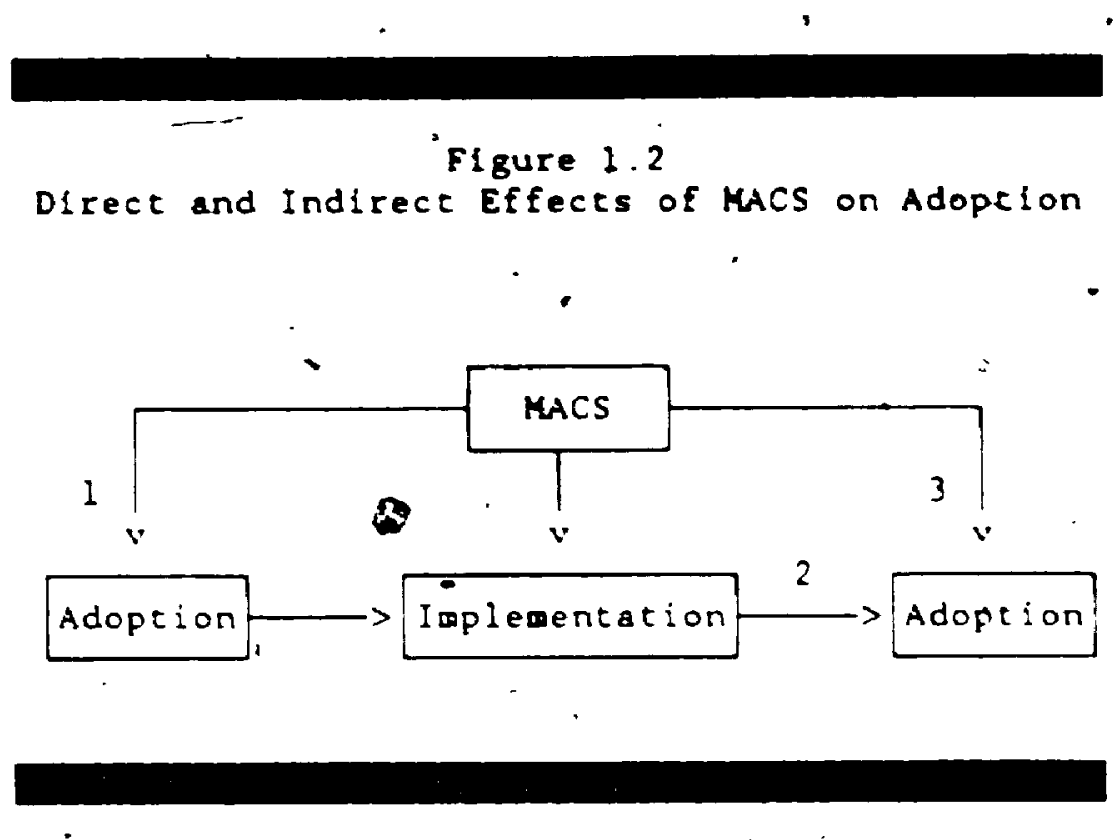

$\checkmark$ B Plant Managers

Plant managers are defined in cerms of two criceria

1. Agtlant manager is a person who makes capltal bydge' proposals to top management but does not have authorlty to epprove them.

2 A plant manager is a person who is responsible tor the operation of a manufacturing plant 6

In choosing to study plant managers: I make two assuaptions that plant managers play an loportant role In the adoption of flextble automation and that the use of MACS for performance measurement and declston-making is approprlate to the production functioli,

i 6 The people identifled as plant eanegers held varlous tities in the saple flras: general anager. director of operatione. operat lon anager. anufarturling wanager. dltector of eanufacturlng. vice. president operations. jpresident. and of course. Plont anager 
Bessant (1982) defiges the adoption of a computer-controlled machine as - "eanufacturing Innovation":

By this is weant the type of Innovition which changes neither the product nor the baslc process, but only sone elements in the process. For example, despite its radical nature, the use of an industrial robot does not change the way in which cars are ade; they are still welded together (p. 119).

Manufacturing innovations are a subset of process innovations. They are equipaent and control systen changes of an incremental nature and are relatively inexpensive. Though a manufacturing innovation may have a strategic implication, purchasing the equipment is usually a taçital decision and is directly influenced by a plant manager (Bessant 1982).

Bessant's views on the role of plant managers axe supported by the Innovation literature which suggests that it is the technical core, the people closest to the technology, that come up with proposals to change that, technology (Daft 1978, Kimberly Evanisko 1981) Zmud 1982). In the context of this study, plant managers woufd be expedted to propose projects within guidelines set by top management and present those project proposals to tog management for thelr approval.

Not all agree that investment in flexible automation ig or should be a

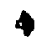
tactical deciston. Some argue that because of its complexity and stateglc Implications, the adoption of flexible automation should be under the purview of top aanagenent (Gold 1982. Tanner 1984). However. even if investment in advanced technologies is not the direct

7 Thle 1. what Broaley et al. (1986) refer to as "bot'com up" capital budgeting and is consletent with the capltal budgeting models described by Bower (1970) and King (1975). 
responsibllity of lower level management, these managers can set up roadblocks to adoption by actively flghting against proposed purchases of flexible autoation, or siaply by not inltiating investaent proposals (Haka 1987. Mitchẹll \& Mabert 1986).

A second assumption loplied in the decision to study manufactuing anagers is that MaCs are an appropriate tool for managing the manufacturing function MaCs have an foportant but limited use in many. sftuations, but MACS are extensively, and appropriately, used in the management of the manufacturing function (Hayes 1977. Otley 1978. Merchant 1981). M.CS are thought to be technically correct for performance mesurement and deciston-making in situations where beliefs about cause and effect relationshtps are complete and standards of desirabilfty crystallized. Such a situation is thought to exist in the buffered enviroriment of the production core (Hayes 1977)

\section{V.C Flexible Automation}

In this study. the term flexible automation is the name of a set which Iricludes the following eanufacturing technologles:

Robots: reprogramable, wult 1 functional anipulators,,$\cdots$ designed co wove workpleces or cools along varlous paths

Cooputer numerical control achlnes (CNC): aevices whlch tool vetal according to programed Instructiona

- Programable Controllers (PC): enall, dedleaced computers used to control or monltor a varlety of production processés. other chian attal eachlning 


\section{$\bullet$}

Autonated materials handling equlpaent: systens used to autonatically move and store parts and raw materials throughout che manufacturing process

Conputer-alded inspection and testing devices: programable devices (Including robots and PCs) used to autonatically aeasure or test production output

CAD/CAM: integratićn between computer-assisted design technologies (CAD) and computer-assisted. nanufacturing (CAM)

This defintion of flexible automation is consistent with the use of

the te: in the literature and in several recent surveys of Canadian manufacturers (Oncario Miristry of Industry, Trade and Technology 1985, Automotive Industry Human Resources Iask Force 1985 . Ontario Centre for Advanced Manufacturing 1986).

Adoption of flexible. automation can be measured at elther plant or multi-plarit (firm) levels. Figure 1.3 shows the various combinations of unft of analysis and control dyad that were considered for this research. Choosing to study plant managers narrowed, the alterriatives to Cell I or 2 but did not resolve the issue of whether to define adoption at plant of firm level. 
Figure 1.3

Choosing Informants and Defining Adoption

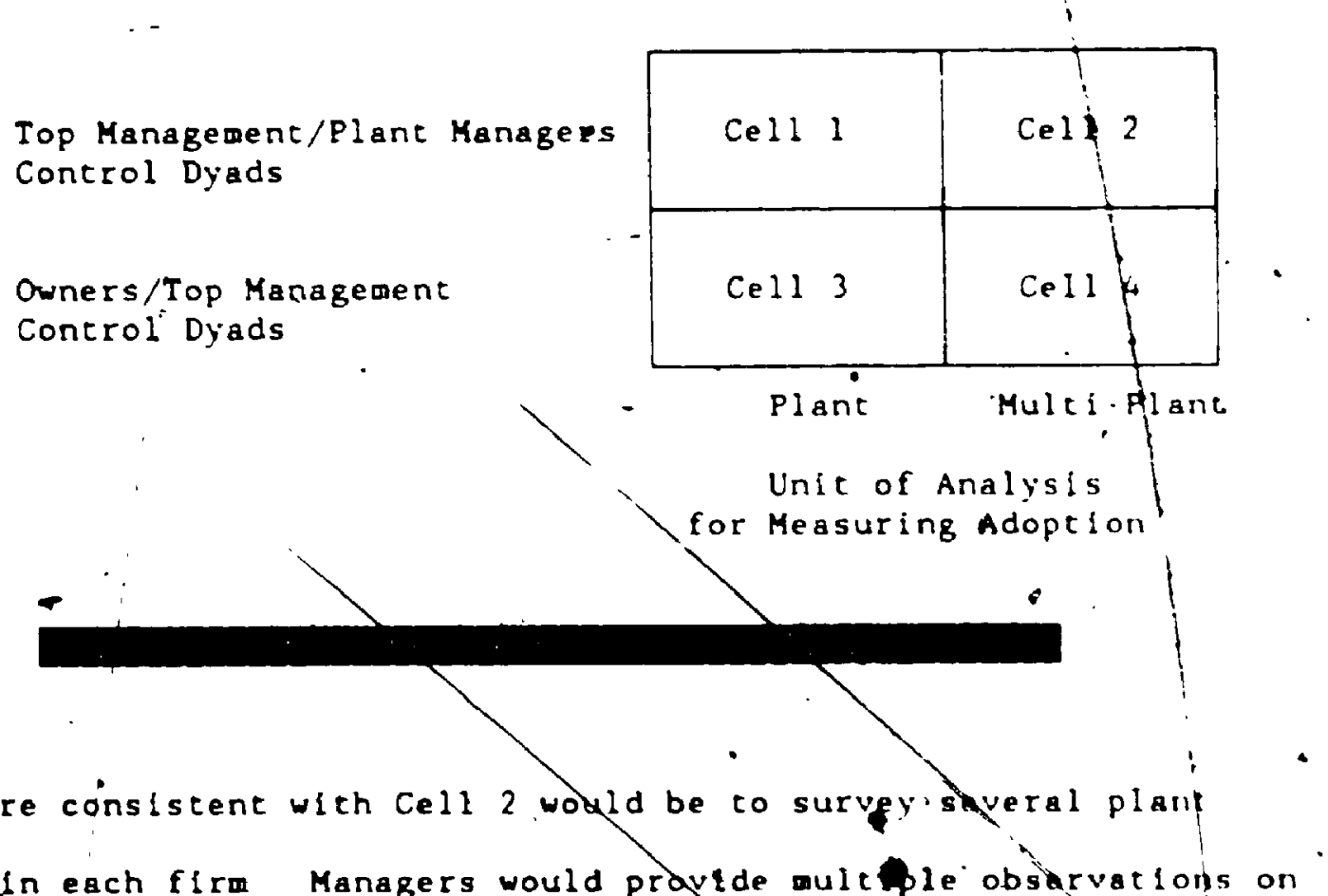
managers in each firm Managers would provide multeple obstrvations on" the characteristics and uses of MaCs for each ira. These obsexvablons. would be averaged in some way and each firm's MaCS scores would be related to an adoption varlable which would ltself be calculated by averaglng the flexible automat! on technologles in the fIrd' plants

The problem with thls approach is that levels of adoption of flexible automation could vary widely mong plants within the sae fira. And. as show by Hopwood (1972), Mey (1978) and HIII (1984). the characterlatic and uses of mas can alo differ fromplant to plant li the rate fita. Thus analyzing macs and edoption at the firg for mults. plent) level would conforing hy reletgonshtp between macs and adopt ion<smiles>CCCCCC</smiles> 
I therefore concluded that a Cell 1 approach would be the appropriate choice for this research and that adoption would be defined in.terms of s. flexible autonation technologies at the plant level. ${ }^{8}$

Section VI: Hrpotheses

VI.A. Model A: Main Hypotheses

The research questlons will be addressed by testing four null hypotheses:

Hil Emphasis on accounting weasures in evaluating $\because$ managers is not related to the leve! of adoption of flexible automation.

H2 The time horizon of accounting measures is not related to the level of adoption of flexible automation.

H3 Emphasis on financial criteria in justifying Investment in flexible automation is not related to the level of adoption of such techrologies.

H4 fifficulty in quantifying the benefits of flexible hutomation is not related to the level of adoption of such technologies.

Table 1.3 describes the flve main constructs in the study and presents interpretations of high and low scores on the varlables that will be used to measure them. Flgure 1.4 is a plctorlal representation of the fpur' hypotheses.

8 In hls study of the automotive Industry, Abernathy (1978) argues for the use of a special unit of analysis that enconpasses "both the product and the characteristlcs of the manufacturing unlt that produced 1t." His unlt of analys ls is the "productive unfe" which is "defined as "an lintegral production process that is located in one blace under a comon management to produce a particular product line." Abernathy notes that an autonotive parts plant is an example of a prodyctive unit. 


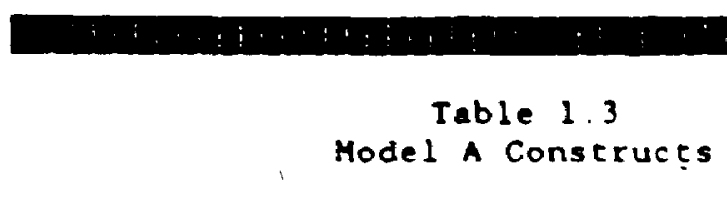

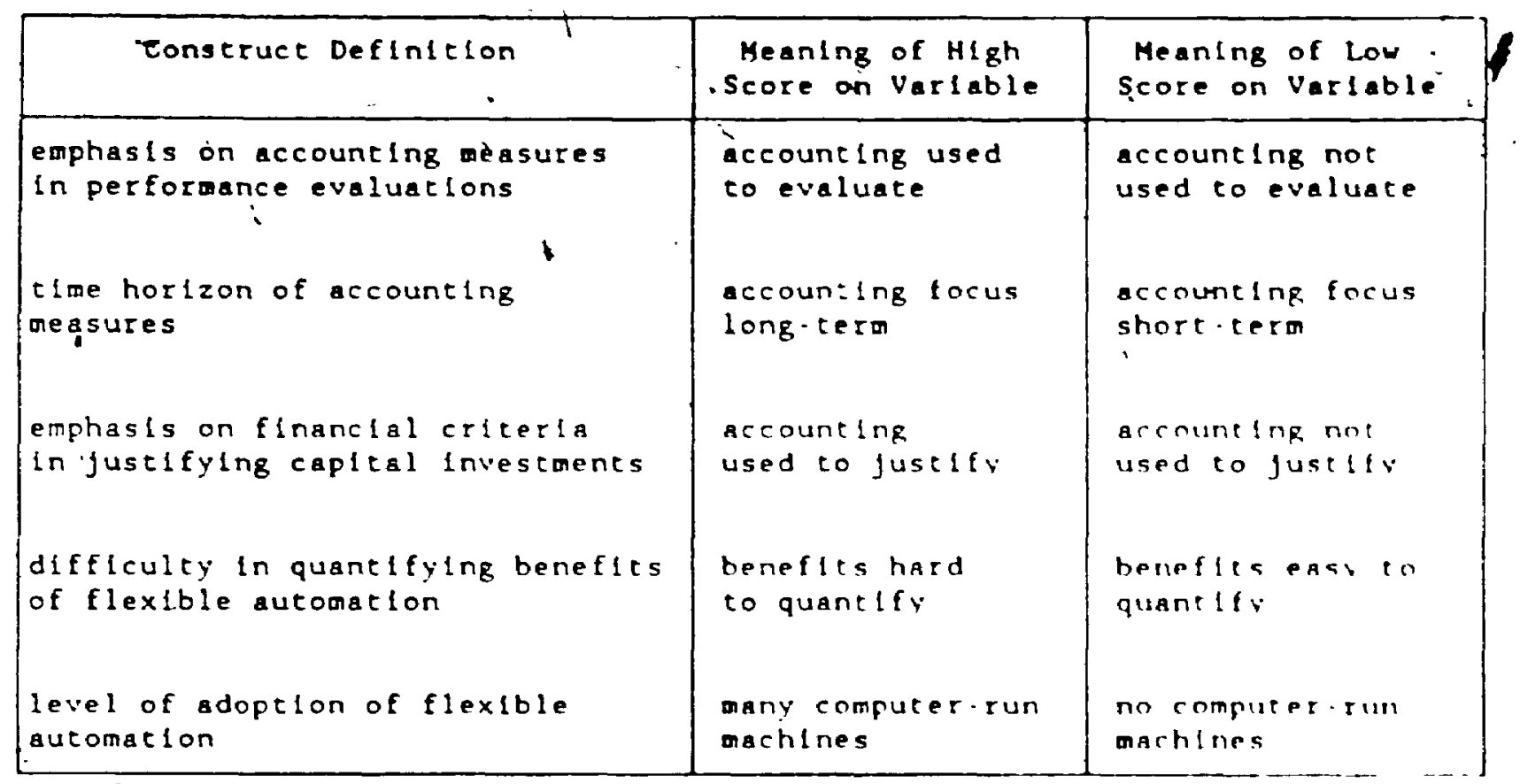

$\checkmark$

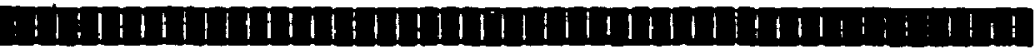

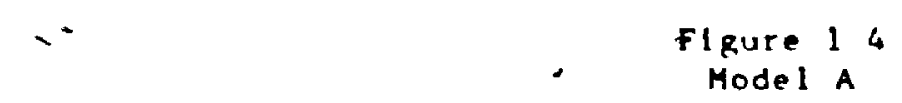

gure 14
Model A
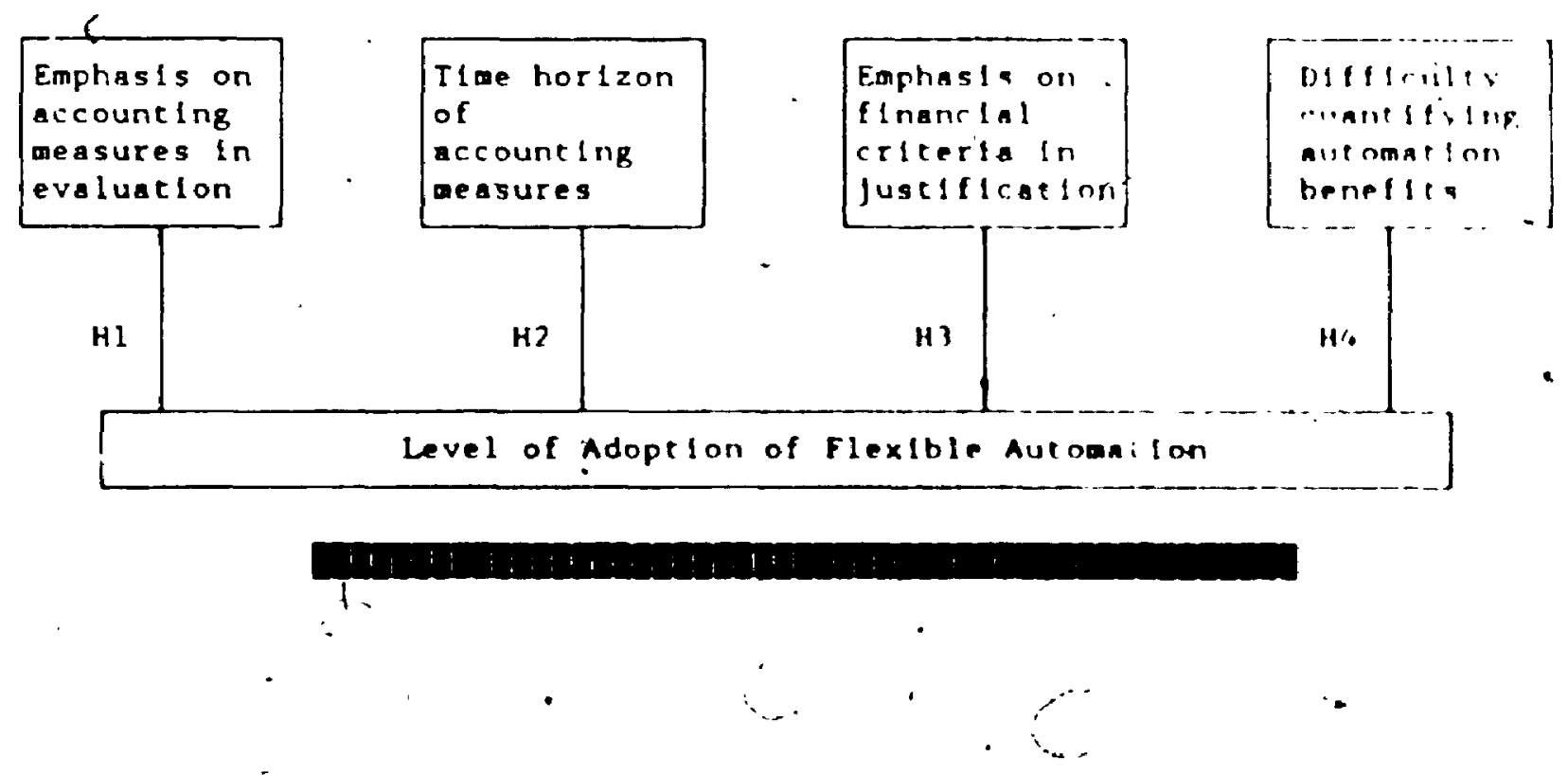
VI. B. Model B: Additlonal Hypotheses

Several studies have looked at the relationship befween MACS and decentralization and between adoption and decentralization. Generally speaking. It is thought that a decentralized organizational structure is positively related to innovation (Rogers 1983). especially when the Innovation relates to the technical core or production process (Daft $\rightarrow$ : 1978). However, Zmud (1982) suggests that while decentralization gay foster the initiation of proposals for new products or processes. adoption itself is more compatible with centralization. This may be especially true when lower level managers are opposed to an innovation:

Innovation may be compatible or incompatible with the interest of organizational members where incompatibility wight be linked to irrelevancy. to fear of change, to the inconvenience of change, to power shifts. etc. Given that a realm of innovation was incompatible with an organization's lower-level members, it is unlikely than any "expansion" in individual initiative broughe about by decentralization would result in increased innovation. More Innovation, in fact, wight be observed if it had been ordained by. a centralized hlerarchy (zoud 1982, p. 1423).

Thus, depending on whether top or lower level managers support or oppose adoption of flexible automation, decentralization may be positively or negatively related to adoption.

The relationship between MACS and decentralization is more stralghtforward. Generally speaking. It is thought that decentralization is positively related to the use of MACs (Bruns of Waterhouse 1975. Merchant 1981). In decentralized organlzations, top management rely on MACS for measuring performance and making investment declalons. 
Herein lies the sced of an inceresting problew. If the relationship anong the MACS varlables, decentralization and adoption is as portrayed in Figure 1.5, then dećentralization aight confound the observed relationships between the MACS varlables and adoption. A fallure to reject $H 1$ or $H 3$ may mean that an emphasis on MACS for evaluation or capital budgeting is not a factor in adoption or that other fo-tors such as decentralization are "interfering" with the impact of Macs on adoption. 9 .

W:

Figure 1.5

Assumed Relationships Among MACS. Decentralization and Adoption
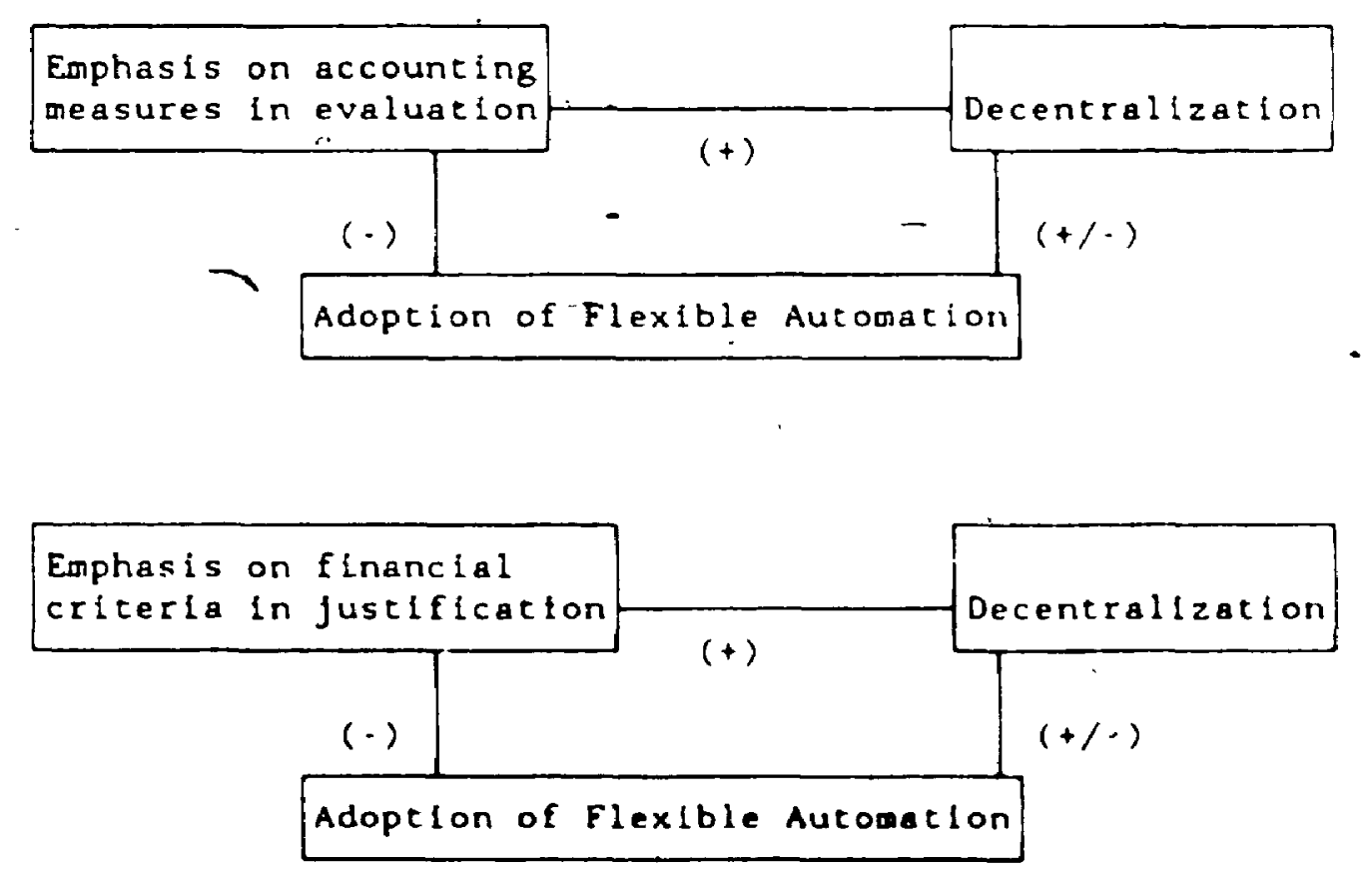

9 The same argument holds $1 \mathrm{HI}$ and $\mathrm{H} 3$ are rejected Tho obierved relationships between the MACS and adoption varlables ans beldue other vartables.

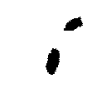


Hodel B examines the relationships among the $H I$ and $H 3$ variables.

adoption and decentralizstion. The two additional hypotheses examined

in this study are:

H5 There is no relationshlp between emphasis on accounting measures in evaluating wanagers and level of adoption of flexible automation after tho effects of decentralizat on are partidled out

H6 There is no relationship between emphasis on financial criceria in fustifying investment in advanted cechnologies and level of adoption of flexible automation, after the effects of decentralization are partialed out.

Figure 1.6 diagrams the ilodel $B$ hypotheses.
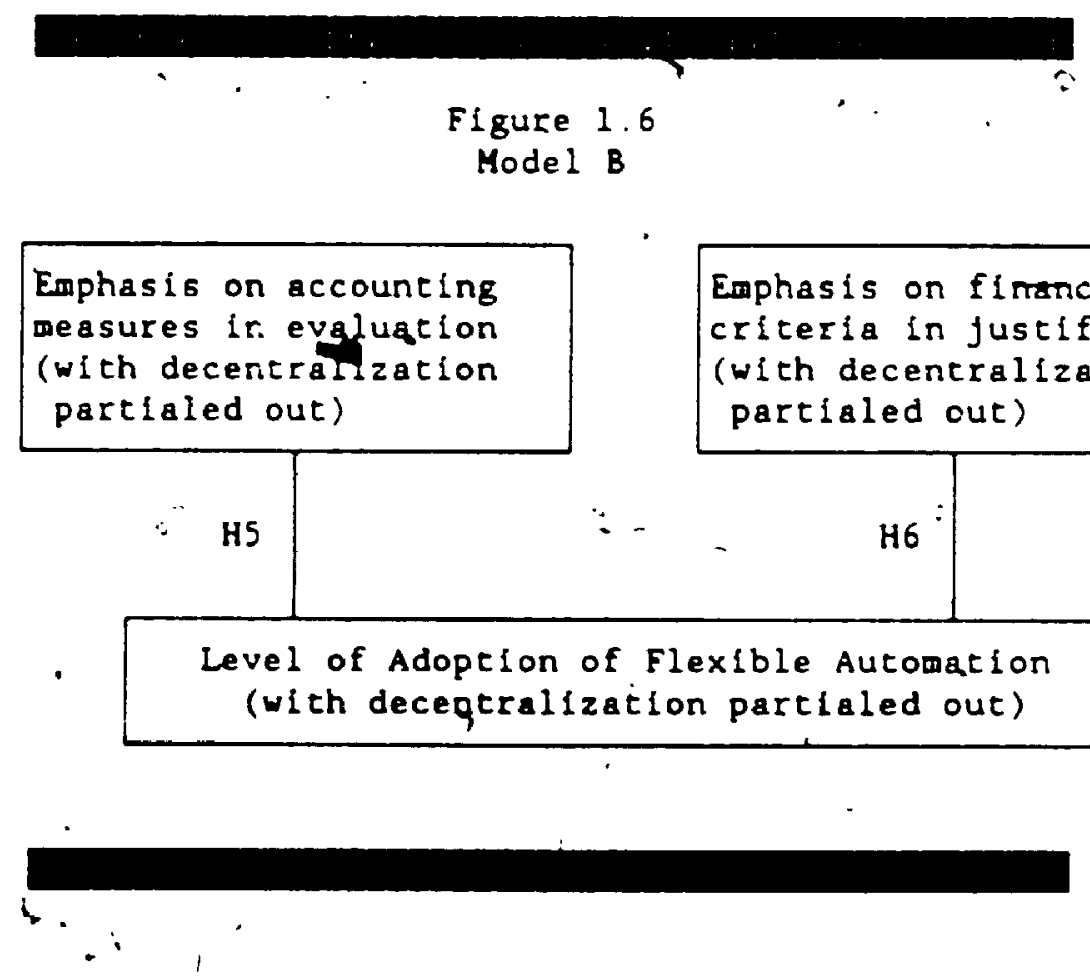

VI.C.Assessing Threats to the Validity of the Resulics

For completeness, and to resolve threats to the validlty of this study.

a nuber of other varlables were neasured and other relationships 
testgd. These "other" variabies ere'introduced in Chapter Four and are described in the context of the discussions of Chapters five and $S i x$.

\section{Section viti Qutline of Remeinine chapcers}

I

Chapter One has' shown that this study is managerially and acadedically:

relevant and has presented a framework for the analysis of six

hypotheses of the relationship between MaCs and adoption of flexible

ptomation. Chapter Two reviews a literature that contends that Mics

blpck the adoption of flextble automation Though this literature

offers a number of yays of surmounting the Macs barrier, it never demonstrates that maCS are a barrier to adoption, nor does it provide evidence that suggested improvements will result in higher levels of adoption. Chapter Three begins with a description of the research methodology and of the sample chosen for the study This is followed by notes, on the four groups of General Motors of Canada part suppliers that particlpated in the study. Chapter four sbows how. the variables in Model $A$ and were operationalized and Chapter Five sumarlzes the research results and presents statjstical tests of the six hypotheses of Models $A$ and $B$. Chapter Six draws some conclusions from the study results and makes some recomendations for future reserct 
CHAPTER TWO

This chapter is divided into three sections. Section I reviews the works of authors who are critical of the role of MACS in the adoption of advanced cechnologies and who prescribe changes to current systems. The objectives of this section are three-fold: to demonstrate their-is a substantial body of literature that assumes that certain characteristics and uses of Macs affect adoption of flexible

1 - automation, to identify those characteristics and uses of macs that are thought to impact on adoption, and to show the need for empirical : evidence to support the presumptions of this literature:

Section II describes the few empirical studies that have examined the role of Macs in the adoption of flexible automation and section III sumarizes the chapter.

Section I: The Nernative Literacure

If this section is to meet its objectives, the works reviewed here must. be seen as being a falr tepresentation of current views on management accounting and adoption of flexible automation. An explanation of the manney in which the vorks were identifled is thus in order. The "Ilteracure review began with a manul search of recent periodicals and was followed, In September, 1986, by a computer search of the ABI/Inform Data Base which references wore than 660 business and management publications frow the United States, Canada, Europe. 
Australia and Japan. A coaputer search of two engineering data bases was also conducted. Though less productive, this search did identify several engineering and production asnagenent journals that were . subsequently Investigated. The process of anual and conputar searches resulted In a lise of 34 books, articles and edicorials which are representative of the literature on MaCS and adoption of advanced cechnologies
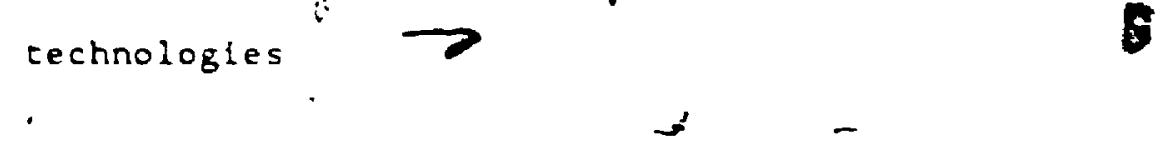

The materials identified in the searches were found to,be almost quticly of a normative nature These materials were coded for content and the results of the coding process are presented in Appendix $A$ and sumarized in Table 21.

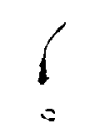

Table 2.1 demonstrates that two cancerns pervade the literature that accounting-based performance evaluations are'overly concerned with the short-tera and that accounting-based fusteflcation processes have difficulty in supporting investments in advanced technologies Simllatly, the coding process conflrmed that most propdsed change; to MACS may be classifledinto one of the following four categorles

1 Top management should place less emphasis on accouncing weasures of performance in the $t r$ evaluation of lower level canagers.

2. Top anagenent should ensure that accounting aeasures properly reflect the long-term objectives of the fira.

3. Top manageaent should plece less emphass on flnanclal cricerla in the fustiflcation of Investments in flexible autoacton

4. Top anagement eppuld make lt easler co Just ffy invertaents in flexible automation by conildering 
sone of the less easliy quantifled benefits of new technologies.

Table 2.1

Coding of the Normative Literature

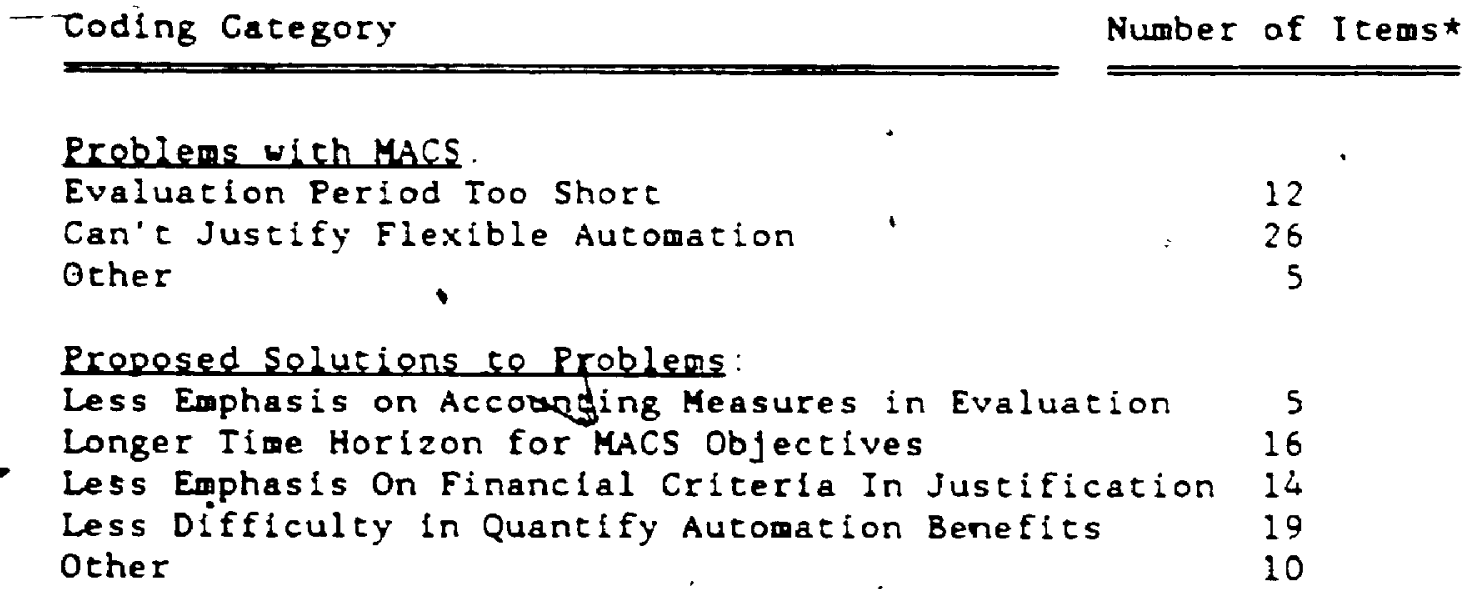

Besearch Mechodelery Empleyed :

Model Bullding/Speculative 16

Personal Experlences/Anecdotes 10

Case Study / Survey 8

Source Jouraal:

Management Literature 13

Production/Engineering Literature 13

Accounting Literature $\quad 8$

* In some cases trems fall into more than one coding

category and thus category, totals may not equal 34.

(Table 2.1 1. a sumary of Appeindix A.)

-

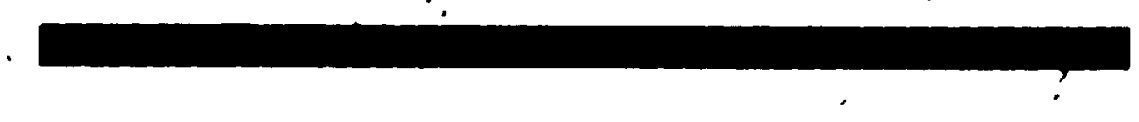

Table 2.1 shows that ofly 8 gf the 34 noraat Ive works eaployed an emplrical methodology. 1 However, none of these amplrical works studied.

1 Methodologios were classified according to a scheme adapted from Kaplan (1986c) and Kelostine Maher (1984). 
accounting and adoption of flexible autonation per se. That is. while 8 of the works were based bn eapirlcal scudies, those studies did not specifically examine the relationship between Macs and adoftion of flexible technology. The authors of these works only speculated on the role of acs in the adoption of flexible automation

The final cacegory in Table 2.1 is "Source Publications " Each of the 34 items of the normative literature were classified into one of three rategories depending on 'whether the ltem's intended audience was general management. production/engineering personnel. Or accountants The remainder of Suction I is an overview of the normative literature organized around these three "target audiences"

\title{
I. The Managemen' Litèrature
}

\begin{abstract}
Picture this: a man in a three plece sult struggies in a tig of war with a robot. The man leans backward trying to pull a bufdle of money out of the robot's grip. The aan's upturned face is cobered with a book. Looking closely you can sed that the book is an accounting ledger. And then you get the plcture: here's a manager blinded by accounting. refusing to Invest in flexible automation
\end{abstract}

The above is a description of a drawing thet introduces an article in Banagenent Jeday (Sheridan 1986). Sherldan critlclzes manabers for maximlzing shore-cerw accounting objectives and for eaphasizing return. on-Investeept and cost savings In fust lfication of advanced 
technologles. He suggests that top anagers should use non-financial

criteria in performance evaluations, that they should adopt longer tige horizons, and that they should link evaluations of investments in new. technologies with strategic thinkfing. He proposes that invescoents in flexible dutonatior. not be justified strictly on cost avoidance but also on Iaproved custöér service, shorter lead times and increased quality. Sheridan concludes:

The wessage is one both for accountants and for general managements. Accountants wust rethink their costing and evaluating systeas. Yesterday's systems cannot $b c$ allowed to be a brake on today's .. let alore tomorrow's -. technological advances... But accounting is too important to be left to the accountants. General management too, must be aware of the drawbacks and deficiencies of their current measuring systems and press for fmprovements. It is. up to top management to ensure that the finance function plays its part ( $p .75$ ).

Sheridan's concern that MaCS preseire matlagers to aim for quick payoffs has been a theme in the management literature for decades (Banks \& Wheelwrigiit 1979 , Rappaport 19/8). However,-the Insidlous effects of short-term accounting goals on flexible automation vere first suggested by Hayes \& Abernathy (1980). In their article. Managing Our Way to Economic Decline," Hayes \& Abernathy ralse a number of alternative hypotheses for what they describe as the decline of North American manufacturing, but ultiagtely they lay a blg part of the blane on MACS:

Having pever lost ight of the need to be technologically coapetitlve over the long run. European and Japanese anagers are extrenely careful to, make the necessary arrangenents and Investents today. And their dally concern with the rather basic lssue of tong-term survival adds porspective to such anters as short-ter ROI or rete of growth. The twae line by which they manage Is long, and it has eade thea palnstakingly attentive to the means for keeping their conpanies technologically competitive. of courses they pay attention to the numbers... But they are also aware that tomorrow wll be no better uniess they constantly try to develop riew processer, enter new ankets, and offer superior -. even unfque - products ( $p .77)$. 
It has been said that no other article in the Harvard Buslness Review's sixty years of publishing "excited quite tho same degree of reaction" as "Managing Our Way to Economfc Decllne" (Kantrow 1983). Indeed Hayes" \& Abernathy's views permeate the normative literature.

In a follow up to Hayes \& Abernathy, Hayes \&, Garvin (1982) shift from criticism of short cerw performance measurements to citicism of the use of the discounted cash flow fDCF? wethod in evaluating investments in advanced technologies. Hayes. Garvin arque that although the DCF method may be suitable for evaluating tactical proposals (eg replating a single machine), It is inapproprtate for examining investments in. advanced technologies. Investments in flexible putopation aust be evaluated from a strategic perspective. Managers must consider the Interdependencles between investments in flexlble automation and how these investments affect their firm's ability to compete'.

The atyack on DCF, one of the coinerstones of "sclentific" management. has increased in the past few years. However. few alternatives have been offered. The Hayes Garvin alternatlve" Is lowering hurdle rales: lower races increase managers' the horlzons and arke flexible automation more atcractive. Pearson (1986) concurs with thls advice He suggests hurdle rates be lowered a few percentage points - . "strateglc discount" - for Investeents in advanced cechnology.

A Dore radical alternative to DCF 1. the application of an options prlcing approach (Myers 1984, Kester 1984, Rlzzl 1984, HIll \& Dlanlk 
1986). Though intuitively attractive, options pricing theory would be difficult to apply" in a fomal analysis of real-world investments.

Kaplan (1986a) contends that there are no "loglc" probleas with DCE but that there are problems in correctly applying DCF techniques. He..... recomends managers calculate the net present value of proposed $\because$ investaents in advanced technology using lowered discount rates and including all quantiffable costs and benefits. The (usualiy) negative value of a proposed investment should then be weighed-against the unquantified befnefits. If management can convince themselvês that the "other benefits" will exceed the cost, then the purchase should be made. In practice. Kaplan's approech ends up being very similar to the options pricing approach (Hill \& Dimnik 1986).

In general, the proposed modifications and alternatives to DCF ask managers to tink investment proposals to overall market strategies and to evaluate proposals on their contribution to the broad goals and objectives of the orgarization. Such suggestions way fly in the face of North American anagements" "preoccupation with analytlc détachment" (Hayes o Abernathy 1980) but they are conelstent with the dapanese way of dolng things:

Japanese firms generally appear to be nuch less "numbers ariven" - then companies in the United states. That is fortultous, since

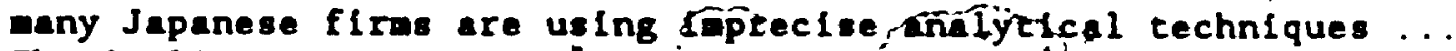
The Ioplication is that the diacutsion and amatjsis of underlying assumptions any be nore Important than the numerical prócessing technique enployed $\therefore$. It aay be that Japanese flras have done a better job of focusing ettention on critfcal input sesumptions including possible scenarlos and anagenent-responses (Hodder 1986. p. 22). 
To sunarize, writers in the managenent licefecure see two probleas with MACS: . the use of short-term accounting weasures in evaluating managenent perforance and the use of analytic techniques $11 \mathrm{ka}$ DCF for strategic investments. Commonly proposed solutions are to lengthen mahagers' time horfizons by lengthening the the period for evaluation and by lowering hurdle rayes, and to employ non-financtal, strategic evaluations of proposed investments.

I. B. Rroduction/Engineertng Literature

The management literature reviewed above attempts to reconclle aggressive technological strategies with fiscal responslbility (Hill \& Dimnik 1986). Implicit in the managementificerature is the . anderstanding that not all technology is good technodogy. This is not the case in the production/engineering literature where the absolute benefits of flexitle automation are taken for grantes and the focus is orr-finding ways to convince top management of the logic of Investing th computer controlled equipó́nt.

(aj

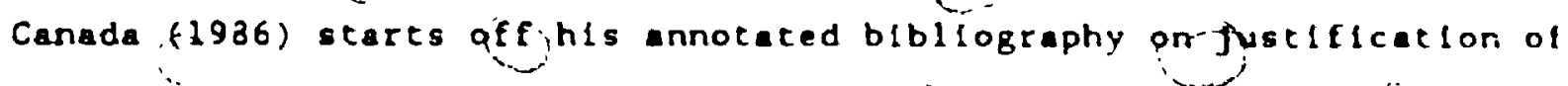
computer-integrated anufacturing (CIM) syoteas with the conient.

Over the past beiveral years there have been Ancreasingly forceful statements by Industry leaders and authors regarding theInadequacles of traditiotrel diecounted cash flow as well is accounting-based dethodologles for evaluating and justifylng CIM eystess. The roots of the percelved friaknesses are that those. craditional rethodologles (1) fall to tedequately quent ify and incorporate the brodd anos-pervasive beneflts of CIM aystans: and
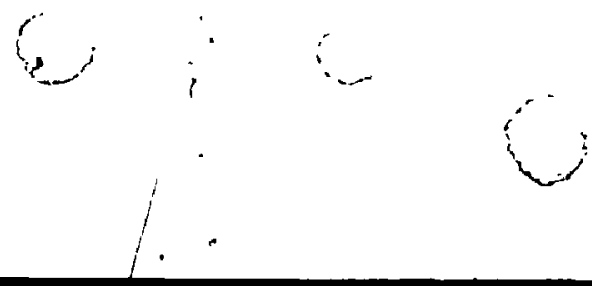
(2) often blind flros to the effects of status quo complacency ( $p$. 137).

- Canada's blbllography includes 52 entries that are "subjective overviews/guidelines on justffication" and 35 itens that demonstrate "quantitative techniques/analysis methodologies for justification." The "subjective" vs "quantitative" dichotomy will be followed in this sumary of the production/englneering literacure.

\section{I.B.1. Subjectloe Overviews/Guldelines}

Many of the "subjective" articles in the production/engineering literature are reports of executive roundtables. For example; Huber (1985) states that "traditional financiar justification procedures ... are quite likely the single greatest barrier to the utflization of new manufacturing technologles by U.S. manufacturing Industries," and then goes on to ask a numbet of executives for their advice on surmounting." the MACS bartier. One suggestion is to include the many unmeasurable benefits of advanced technologies in the justification process.

Another suggestion Is tolénsure the investment process is driven by a long-range competitlve strategy: Huber concludes with a few brief case -tudies of successful adoptions. The cases show that top aanagement has had to de-emphaslze traditional financlal methods of avaluation in order to pronote the adoption of flexible aucomation. For example. Allen-Bradley President J.T. O'Rourke says that hls company's investment in a compter-controlled production ine would not have been ade had the profect been evaluated on the basis of the "old ROA. methods." 
Similar sentiments are expréssed in an article by Gene:al Electric executive; $F$. Curtis, who tells managers they aust grasp two basic concepts: traditional "hard-number" methods of economic justffication just don't work any more and one should not be afraid of "soft numbers" (Edicors of Material Handling and Engineering 1985)

I.B. 2. Quant ltative Technlques/Analysis Methodologies

The threatened abandonent of traditional quantitative techniques has caused some consternation in the ranks of experts on the tapic

To ensure a progresive future, engineering economic analys is "procedures and approaches must evolve to evaluate the econònic aspects of changing technology, or alternative technlques will he. found to justify new purchases and innovative designs we already nalize some of these ney techniques in the justlfication of new technology - r roboticts. flexible manufacturing systems, software systems, etc. - by the use of vague reasons such as "technolngy." "labour replacement." "competition." etc. when classical economic analysis shows the suggested design to be a poor or rlsky cholce (Blank 1985, P 227).

Blank (1985) discusses three ways in which engineering, econoulcs is adaping to the-need for new methods of Justification incorporatifip. eleaents of strateglc.planning in investrent analyses, Iaproving * estimation and tracking of cost compqnents, and designing and psinp. . sofeware systems. In analyzlng Invescuent proposals

Utect.t (1986) and Powell.*(1986) ident lfy sove of the beneflts not noraalky considered in the evaluation of flextble eutomation proponals Bernard (1986), whlle agreeing uth the need far eretegy-orlented Dethods of fustificetion. argues that such an approach is not poestble 
using the accounting profession's "highly structured methods" of allocating resources:

... Convincing top managenent of the need to invest in new technology and then justifying it is often wore of an art than $a$ science. Rather than relying on some type of "creative" accounting procedure to reduce all of the Intangibles to dollars and cents in order to calculate a precise econonic answer using inprecise or highly subjective source data, one approach is to use some type of structured profect methodology to analyze the relative advantages and dlsadvantages to the firm ( $p$. 52).

Bernard goes on to present a non-financial, multi-criteria evaluation technique for investments in new technology: Taking a similar tack, $\bullet$ Frazelle (1985) and Sullivan (1986) recommend evaluation techniques that require managers to identify financial and non-financial criteria (eg. ROI, flexibility, safety, compatibility, maintainability), to subjectively weigh the criteria, and to rank alternative proposals according to the weighted criteria.

To sum up the production/engineering literature, there is a consensus that changes must be made, to current accounting practices. One group. mostly production managers, suggests that investments in flexpble management cannot be analyzed by conventional methods. They advocate making invastments on faith. Academics and professianal engineers are respordirg to the criticlsms of tradltional fustiflcation methods by suggesting improvements to those inethods and by developing alternatives to then. There is general agreesent that financial issues should be downplayed In favour of strateglc lasues and that more of the "soft" benefits of flexible automation should be considered in the justification process. 


\section{I.C.Accounting Literature}

$-$

$\because$ Kaplan (1983) issues a challenge to management accountants to "devise new internal accounting systems that w: 11 be supportive of the firm's new manufacturing strategy. "In particular, he suggests the need for non-financial and longer-term measures of managerial performance and for new measures of the less-easily quantified benefics of advanced eechnologies that should be included in the justification process

Kaplan (1984b) argtes that inadequacies in gxisting performance measurement systems are hindering transitions to the organization and technology required for the "new industrial competition "He notes that "a narrow-minded focus on short-term financial indicators" can distort a firm's fixed asset acquisition program and that firms must "de-emphasize the use of accounting profits to measure near-term performance." Kaplan suggests that general managers augment account inp. measures of performance with direct observation "Management by Walking About will have to replace Managing by the, Numbers 2
\end{abstract}

Kaplan (1985) cestifies tha the basic production model at the core of management accounting research and analysis is man overly andifled. perhags absolete representation of the production iluation confronted by corporations in the $1980^{\circ} \mathrm{s}$. He polntis out that so celled optian

2 Bruns o waterhouse (1975) equate decentralization with "management by numbers" and centralizatlon wlth management by walk!ng, about. " Thus Kaplan 1s. In effect. advocating a ore centralized management structure 
decisions" of a traditional anagenent accounting model are optinal "only if the condiclons and parameters of the nodel are assuned to be lanutable with respect to aanagerial actionso" As an example, Kaplan cites how japanese anagers "stepped outside the pounds" of the

- traditional inventory model to ask not "what is the optimal quantity of inventory" but. "what conditions do we have to change to eliminate the need to hold any inventory at all." The implication for adoption of flexible automation is that managers may havè to step outside treditional accouncing systems to make decisions about purchasing. computer-controlled machinery.

Kaplan's work has not gone without comment. In Atkinson s tumings (1986). Cummings argues that traditlonal MACs are not being used properly: -if you use numbers without knowing the facts behind them and what the numbers mean, you can make dumb wistakes." Cummings downplays the suggestion that MACS are causing major problems and that they are insppropriate for new technology. He points out that "most people are motivated, not only for this year, but for the next year and the year after that." It is difficult for managers to short-change the future for short-cerm success because their reputations travel with them. In any case, managers, like other people, are more concerned with seturity and long-term survival than with short-term success. Cumings agrees with Kaplen that - Innovation is sodething that isn't meesured at all by an accounting syeted." and thet thl ahortconing can; only be overcone by the direct lnvolvejent of top managenent. However. disagreeing with_Kaplan, he argues that MACS can actually be a positive

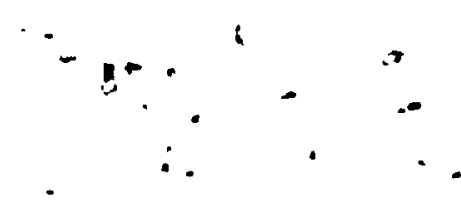


force for adaptation to changing enviroments. For example. In situations where managers are evaluaced on the basis. of ROI, top management can encourage faster asset replacement by placing higher values on old assets (fe. depreclating them nore slowly and marking " them up by inflation indices).

?

Looking at some other works in the accuunting literature. McLean (1986) claims that British top mangement still see manufacturing as a "cost sink" and not as a competitive weapon Macs emphasize dost control and cost savings and do not provide information needed for stratégic decisions. Emphasis on accounting measures makes cost avoidance a top priortey in manufacturing and forces managers to avoid investing in much nèeded new rechnology.

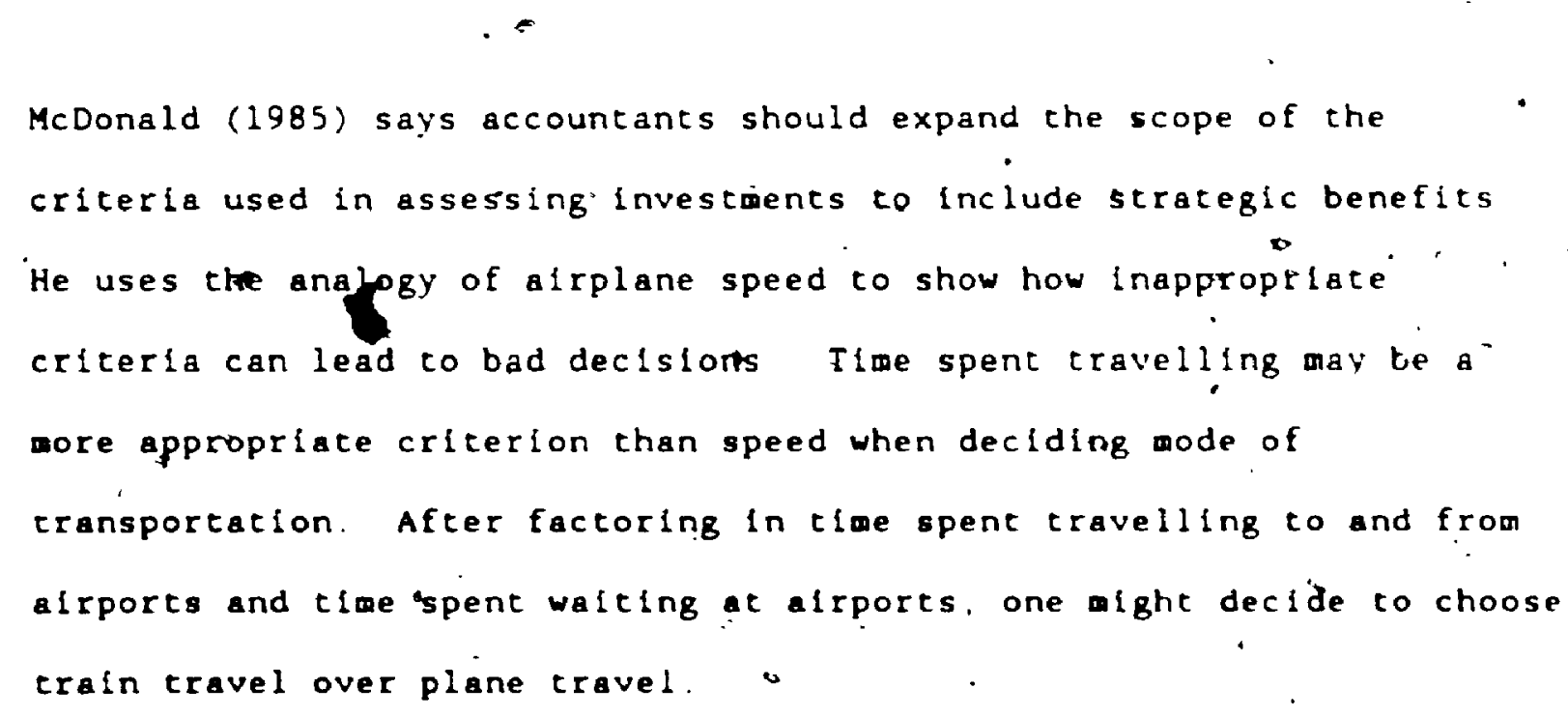

- Merchant \& Bruns (1986) suggest -different weasurements that aght lead to \& cure for anagement dyopla and selfishess " They first develop" criterla for evaluating weasurement alternatives and then recomend top 
managenent be rewarded in proportioip to the returns realized by the shareholders." They have more difficulty devising perforance masures for widdle manars and end up proposing a system that combines features of a cash flow system and an economic return system.

The use of discounted cast flow analysis (DCF) has also come under scrutiny in the accounting literature. Primrose et al (1984) defend DCF and say problems caused by poor assumptions and misuse of the technique may be rectified by using the authors computerized decisionmaking program

Section UI: Empitical Accouncing Research

Only one empirical study focuses on the relationship between rics and the sdoption of flexible automation. Woods et al (1985) looked at the capltal budgeting procedures of 92 mechanical engineering firms in the U.K. and found significant differences in the investment appraisal methods of adopters and non-adópters of CAD/CAM technology. Table 2.2 shows that non-adopters were wore likely to make use of non-financial s and "other than DCF/Payback appralsal methods" than adopters. This result appears to contradfct the normative literature becduse it suggests the adoptian of advanced technology is positively related to the use of tradielqnal justification methods. 

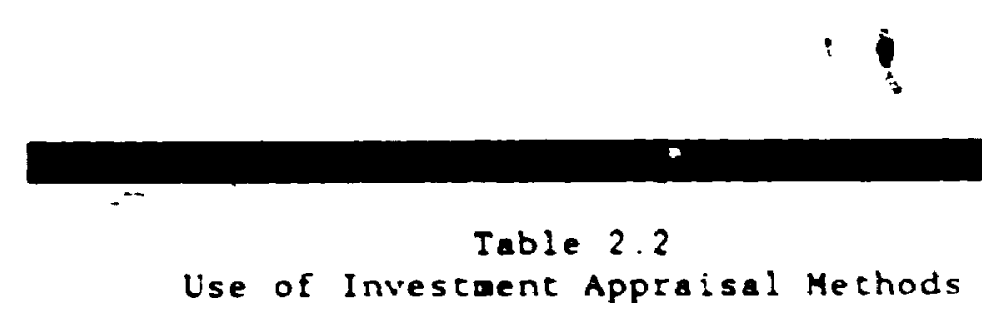

\begin{tabular}{|c|c|c|c|c|}
\hline \multirow[t]{2}{*}{ Method } & \multicolumn{2}{|c|}{ Adopters } & \multicolumn{2}{|c|}{ Non-Adopters } \\
\hline & Numbers & Percent & Nubbers & Percent \\
\hline Payback & 36 & 57 & 10 & 34 \\
\hline DCF & 0 & 14 & 3 & 10 \\
\hline Boch & $?$ & 11 & 3 & 10 \\
\hline Non-Financ:al & 4 & 6 & 4 & $\therefore$ \\
\hline other & $?$ & 11 & 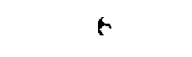 & $\therefore$ \\
\hline Firms & 63 & 100 & $? 4$ & 10. \\
\hline
\end{tabular}

From Woods Pokorny, Linener Blinkhorn (108:

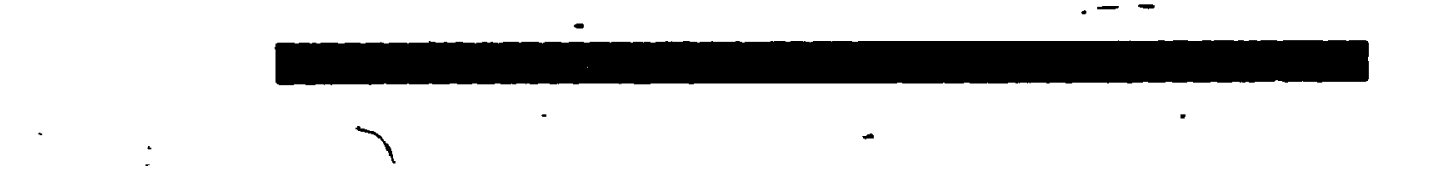

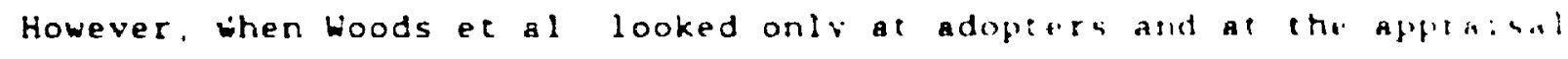
methods spec:fically used for CAD/CAM svstems. thri inum J' pul ant of the adopters did not calculate "spectflc costs expected reverius and depreciaced cash flows in just fothe advanced techmolop!ry ispr Table 2 3) The authors interpret the results as s!gnifving." recognition of the limited practical use of formal appralsal orticits when dealing with rlsky or uncertaln invescoerits : 
Table 2.3

Appraisal Methods for Flexible Automation in Adopters

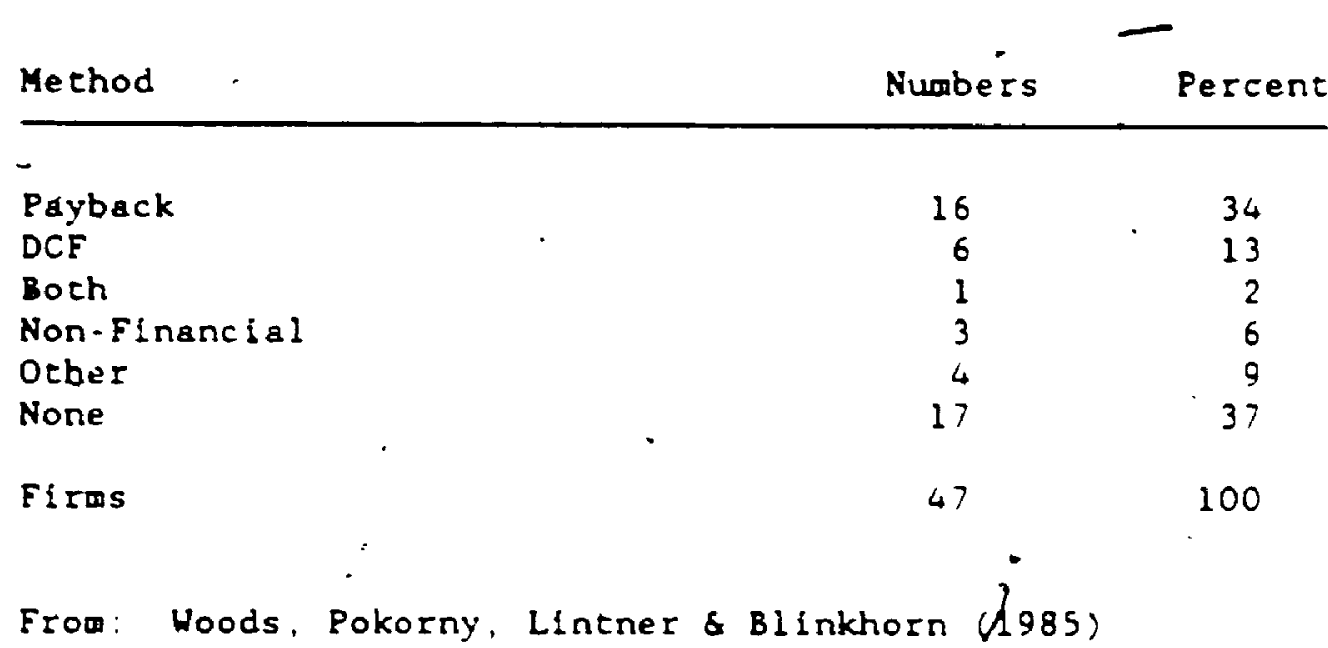

The Woods et. al. study also found that of $30 \mathrm{firms}$ that used flexible payback perlods to evaluate projects, "shortening of payback in response to the risk association with new technology was the single most Important reason cited for payback flexibllity.." This result is unexpected. If anything, one wight expect longer payback perlods ta be positively asociated with adoption of flexible automation. ${ }^{3}$

Woods et al. summarize their findings:

The survey' ... 'shows ... a widespread acknowledgement that risk cannot be dealt with objectively in the context of a capital - budgeting systen and that instead, firms are nore in favour of $\longrightarrow$ -

3 The normative literature clalus that lowering hurdle rates and incteasing length of payback crfterla would promote investient in advanced technologles. 
subjective judgent and assessment of Investment decistons. abandoning formal invesement appralsal altogether (p 43)

Two ocher eapirfcal scudies are peripherally related to the thesis tople. Schwarzbach (1985) surveyed 112 manifacturing firas to see if there were any relationships between automation and the way the firms accoanted for indirect coses Schwarzbach operationallied - level ot automation" by asking the "person most knowledgeable about cost accounting" in each firm to rate level-of automation on a single : irs Respondenis were asked to circle a number from to 10 . th rempinc i.. the question "To that extent is your product:on process now "automated?" Sophistication of the accounting sistem was operationalized by weasuring the kind of cost system used, the aminul. of calculating overhead rates and the methods of deprectation Schwarzbach found no demonstrable relationshlp between level of automation and the "sopkistlcation of the acrounting system"

Kaplan (1986b) studied four American firms choseri for bellip rithet neaders in high-technology growth Industries or flros lin antwer Industrles who were actively promoting productivity and new manufacturing technologies 4 Kaplan concluded. Wth looe pident

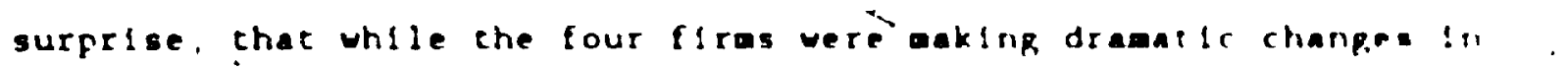
thelr mechods of production. they vere not anklng compatale changrs In

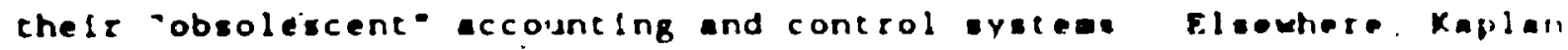

$4^{\circ}$ Troberg (1986) coployed a - In!ler methodology in his - tud. of European compariles and echoed eany of Kaplan' conclue! orie 
(1984a) has argued that historically any accounting cnange that gave Its users an economic advantage has been quickly acopted. Given that the four firms chosen for the study were "among the best nanaged and most successful U.S. corporations, " It.scens rather pecullar that top " anagement of these firms would weste resources on "obsolescent" systems. Though Kaplan's focus is on MiAcs and the implementation of advanced technologifs, he leaves one wondering about the role of MACS. in adoption: Are North American ffrms adopting flexible automation despite iraditional accounting methods, because of traditional accounting methods. Or does accounting matter at al1?

\section{section III: chapcer sumary}

A basic premise of the widespread literature on MACS and advanced technologies is that traditional accounting methods are inhibiting the adoption of flexible automation. The literature review in this chapter Identifled those aspects of accounting thought to impact on the adoption of flexible automation. The review showed there is $a$ .distressing absence of evidence supporthig the existence of any relationship, positive or negative, between characterfstics and uses of accounting and adoption of flexfble autoantion. Despite theis willingress ta declare certain espects of MACs as anathemas to the process of adoption, there are fow auchors who offer any realistic and practical alternatives to the criflclied prectices. Clearly, research I. needed to deteralne which, If any, espects of Macs are related to the adoption of flexible autonation, and how Macs, or practical 
alternatives to MACS, way be used to support autonation scrategles. The next chapter describes a methodology foresearching sone of these issues.

0
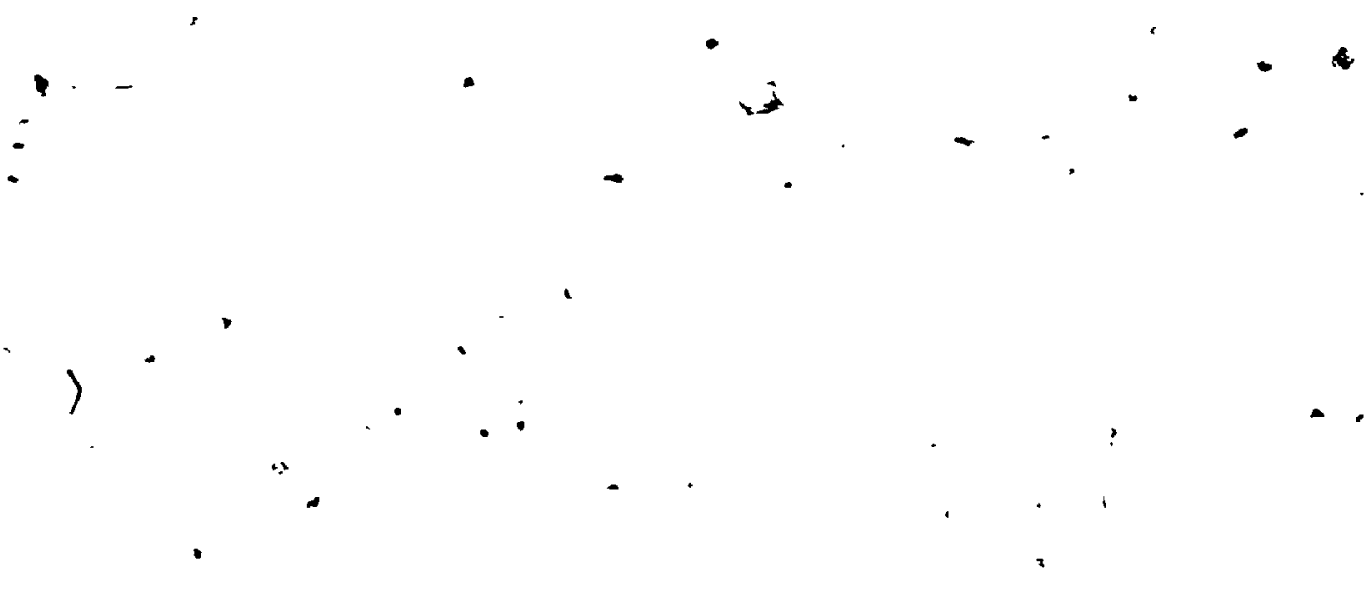

1

\section{$\div$}


This chapter is divided into three sections. Section I, which presents the research methodology, Is organized arourid the decisions that were made in developing cests of the hypotheses outlined in Chapter One Section' II describes the data collection proces and section III. describes the fqur, groups of automotive part manufacturers chosen For the study.

Section I: Mechódelesy.

The four methodological decisions discussed in this section are:

the decision to conduct empirical research, the decision to study manufacturers of automotive parts, the decision to sample General Motors of Canada part suppliers, and the decision to use both mail questionnafres and personal interviews tc collect data.

\section{I.A.Choosing Emplrical Research}

As shown in Chapter Two, there is a dearth of empirical research on MACS and adoption of flexible automation. Kaplan (1983, 1986b) and Troberg (1986) urge those who would study MACS and advaneed technologies to "leave thelr offices and study the practices of Innoyating organizations." Kaplan (1986c) etates:

- I too hiave expressed my concern wth the lack of field-based research strategy in aanagement accounting. Major changes in the organization and technology of a flrm's operations may be making the accounting and control ystens of corporations $\approx$ 
some variability in adoption of flexible sutomation. What was needed was a population where sone, but not all. plants were known to have some flexible autonation.

\section{I.C.Choosing a Sample of Plants and Managers}

The population of Canadian plants that suppiy parts to automotive assemblers would seem to satisfy the three criteria listed above. 1 The automotive industry is one of only a few that can weet the third criterion: evidence of some variabllicy in levels of adoption. Table 3.1 shows the adoption levels of various flexible automation technolngies in the automotive industry as reported in two recent studies. These adoption levels may appear to be low, but the automotive industry leads most other sectors in adoption of advanced technologies (Ontario Centre for Advanced Manufacturing, 1986. Economic Councll of Cariade 1987). For example, 70 ' of the robots in Canada are Installed In plants in the automotive Industry (Ontario Ministry of Industry. Trade and Technology 1985).

1 Firms that manufacture automotive parts are often described as "second-tiered firms" :

Firas, regardless of size, which have very linced number of custoners and are therefore selling in an ol fgopsony. . The industry sub-set. . Includes firms thet manufadfurd autonotive equipeent, eccessorles, parts, components, supplses, or subassemblias but do not assemble these ltens into complete motor vehicles (Martin 1984, p. 3). 


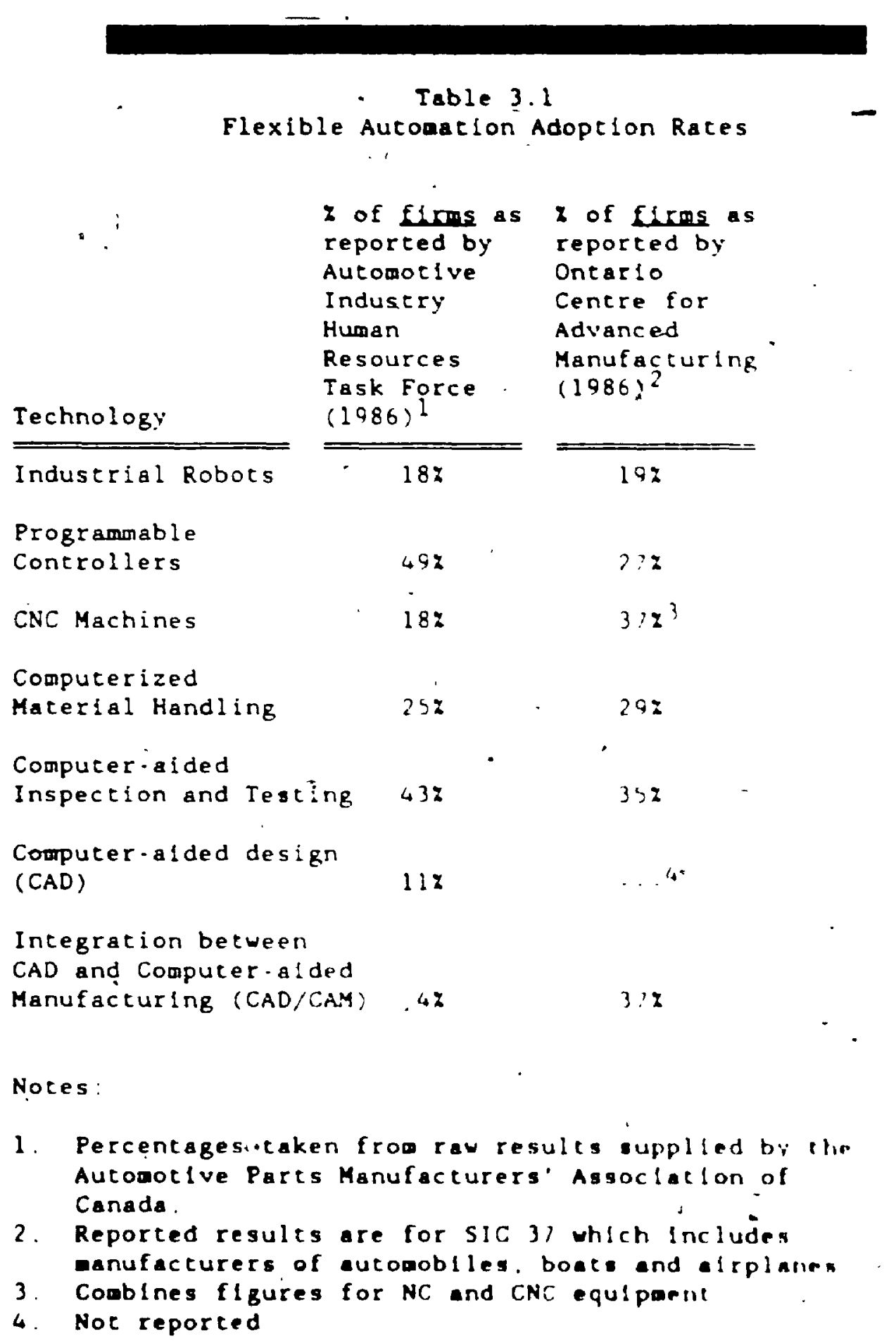


Besides meting the three format criteris, the study of plants in the automotive parts industry had two other things to recomend it. The autonotive industry is a vital part of the Canadian and American econonles and the industry is a bellwether for global competition and technologlcal change.

After a preliminary inveselgation inco creacing a sampling Erame for the study, it was decided to approach the management of Canada's largest automotive assembler, General MQtors of Canada (GMC), and ask for their assistance in Identifying and contactiog their part suppliers. ${ }^{2}$ Managers in the automotlve indusfy are inundated with requests for information from Industry, government and academic researchers. A study supported by GMC would likely be better received than an unsponsored study. Limfting the study to GMC suppliers might. result in some lass of generalizablily but that loss would be offset by the reduction of environmental nolse and by the entree offered by GMC...

There are more than 250 suppliers of parts to GMC. ${ }^{3}$ As explained later in in this chapter, a decision was made to employ a two-wave data collection process: mall questionnalres and personal interviews/plant visits. The regulrament to physically visit gach plant made it

2 General Motors of Canada Linited (GMC) is operated as a division, of General Motors (GM).

3 There are more than 400 second-tler parts suppliers in Canada (Autonotive Industry Human Resources Task Force 986 ). More than half. of the second-clered firms in Canada do some bustiness with GrC. 
necessary to select a auch saller sample of GMC pact suppliers. The process by which that smaller sample was selected is sumarized in Figure 3.1 and described in detall in the fol kwing pages. 4

1

Figure 3.1

Process of Selecting a Research Sample

$\therefore$

$400+$ Second. Iiered Firms in Canada<smiles>C1CCCCC1</smiles>

$250+$ GMC Part Suppliers

$1=$

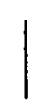

51 Plants from Four GMC Product ciroups $c^{\text {Selected for seudy }}$

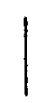

32 Plants and Plant Managers

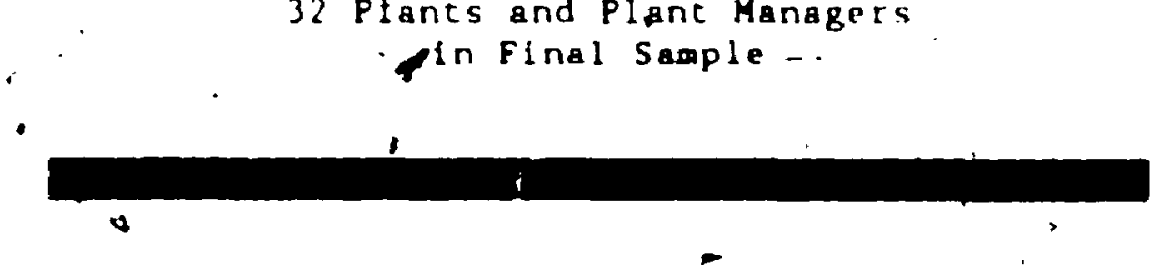

In consultation with GKC managedent, Fldentlfied 51 plants in four product groups that represented a wide variety of manufacturimp. processes: Detal;otapers, plastic wolders and finlahers. rubber parts manufactureis and functioñal and decorative die casters Loosely

4 The ters "flro" refers to coopeny uth one or pore eanufacturing plants To the best of ay knowledge. the plante that partlcipated in the etudy are owned by 32 different fires and thur ihr tero "fIro" and "plant" are usod Interchangeably in thle context 3 


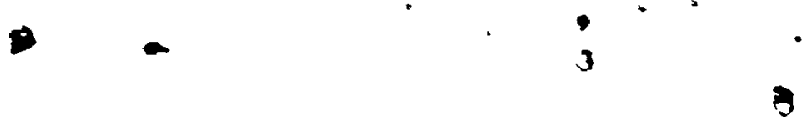

8

speaking, each group could be called a comodicles group: plones in each group are not necessarliy competitors but they do manufacture - Inilar products and eaploy similar manufacturing processes. 5

I.C.1."A Prlorfmi Measures of Adoption and Plant Petormance

Before contacting management of the 51 plants: I attempted to answer three questions:

1. Do top managers of the 51 supplier firms support the adoption of flexible atomation? Differences in top management preference for flexible automation may be responsfble. for dufferences in levels of adoption. Ideadly, to contral for

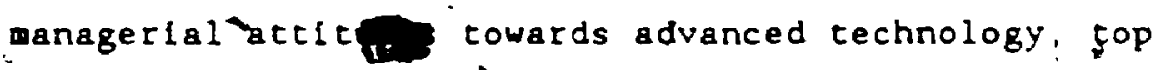
management of plants in the sample should support adoption of flexible automation. 6

2. Do the 51 pidents have oufficlent variablitig in adoption of flexible atometion? Earlier, I noted that the automotive Industry is one of only a few that has invested in fiexible automation. If top management of GMC part suppliers generally

5 There are no "ready-made" product grouplngs in the autonotive Industry. The Autosotive Industry Action Group, a voluntary association of assenblers and suppliers, once set up a couittee to, $\therefore$ devise a oysten of classlfying ouppllers but after a yoar of deliberations, the comletee gave up on the attenpt.

6 This requlrament is consistent with the Chapter One discussion of control. and top management/plant manager control dyads. 
favour the adoption of flexible autoation then most plants in the sample aay have sinilar, high levels of adoption and this cross-sectional study may not be able to distingulsh amiong factors related to adoption. There must be some variability - In adoptior. Is there ary of checking for self-selection biss in the fanal sample? Empirical research is often cricicized for response bias. "successful", firms are thought to be more likely to participate in studies than "less successful" ones - Not all 51 firms invited to take part in the study could be expected to participate and so there should be some check on whether the participating plants differ from non-participating plants on two key measures: adoption of flexible altomation and overall performance as GMC part suppliers: Measures of adoption and.performance of parjiclpants and non-partictpants would be requilred to cest. response blas.

The issties raised by thesa chree questions will be addressed in two parts: First, I will,present evidence that top management of GMC part suppliers support the adoption of flextble automation in their firms. Then, I wili describe survey of GKC personnel that provided information on varlablilty of the adoption barfable and on response bles. 
I.C. 2. Gorl Congruence in the Gr Suppller Netrork

It is proposed that top wanagenent of GMC part suppliers support the adoption of flexible automation. Proof of this assertion would require

Ither a survey of supplier top management or of those who could coment on the attitudes of these managers. ${ }^{7}$ Nelther option was

feasible in the context of the proposed research Therefore, I will provide circumstantial evidence that top management of supplier firms support flexible atomazion. First, I will show that GM management has stated and implemented a strategy of investment in advanced manufacturing technologies. Next. I will show that this strategy has been communicated to top management of part suppliers and finally, I will argue that it would be to the advantage of current and potential GMC part suppliers to embrace a high-tech manufacturing strategyे.

Several studies have examined the automotive industry from global, Nórth American, and Canadian perspectives (Jones 1985, Naclonal. Academy of Englneering 1982, Reglonal Industrial Expanston 1983). For all the reasons discussed in Chapter One, these studfes bave recomended that assemblers and their suppliers invest in state-of-the art manufacturing

7 Plant ganagers should be able to coment on whether their superlors support the adoption of flexible autonation and 0. I asked respondents to agtee or disagree with the statement: Top. managenent of this company wante nore flexible axtomation. On a sale of 1-strongly disagree, 3tratral, and 5-strongly agree, the mean respones was 3.5 , Indlcating that top anagement of the firas in the sample support the adoption of flexible autoartion. This result confirms the goal congruence irgument developed in thls section but of course "the result was realized only fiter the survey was conducted. 
rechnologies. 8 GM anagenent has taken the high-tech prescriptions co heart.

Since Ehe early $1980^{\prime}$ and his ascension to the Chairmanship of GM.

Roger Swith has pursued a high-tech strategy for his company. Smith

has been described as the CEO who is "turning GM toward a technological

10

revolution" (Williams \& Shultis 1984) and in countless media interviews

he has declared that his "deepest passion" Is to upgrade GM's

Eechnology (Greenwald 1985)

Smith's strategy has befn reiterated by dther GM top management GM

Executive Vice President Lloyd E. Reuss, considered a possible

successor to Roger Smith, is quoted In an October 10, 1987, company

press release:

If American business is to meet the global competitive challenges of the future, each company has to "search" relentlessly" for new ways to cut lead times, exploit technology and Innovate faster [sald Reuss]. Mr. Reuss said GM attaches special Importance to innovation and technology.

"We've made major technological changes at GH already - and we're golng to aake a lot more," he sald. "A company should not shy away from an aggresgive approach to technological Innovation ... It's a key element in competing with low wage

8 . While the clted studies recognize the loportance of arnufacturing innovations, they note that simply investing in new technologles is not enough:

Popular accounts of the energence of Japanese producers as firstrate, worldwide competitors-tend to emphasize the lapact of the new automation technology (eg. robotics). etrong support of the central governaent. and Influence of Japanese culture... There is no doubt that these factors have played some iole: Yet, It Is our view that the sources of the Japanese advantage are...rooted in a comitment to anufacturing excellence and a etrat'egy that uses manufacturing as cumpetitive weapon (National Academy of Engineering 1982. PP. $99-100)$. 
countries ... The end polnt of coupetitiveness 1 s products of increasingly high qualfty and value."

Note that Reuss' statement alludes to any of the conpetitive advantages of flexible automation that were discussed in Chapter One. Also note the expectation that other companies take a mote aggressive approach to technological innovation.

The 1984, 1985 and 1986 Geners Weters Annual Reports trumpet GM's investments in flexible manufacturing. For example. the 1984 Annual Report has 17 pictures of computer controlled manufacturing technologies Including robotic welders, automatic guided vehicle systems, and painting robots. The 1987 Annual reports devotes an entire section to "Investing in the Future: Technological Advancement" and the 1987 General Meters Public Interest Report states that from 1980 to'1986. GM Invested wore than $\$ 50$ billion (U.S.) in new , facilities, tools and equipane.

GM has also upgraded its technology through purchases of several high. tech companies (Electronic Data Systems Corporation and Huzhes Alrcraft Company) and through joint (entures. An example of the latter is GMF Robotics, a folnt venture with Fujltsu Fanuc, a major Japanese manufacturer of industrial robots. GMF has become the biggest U.S. robotics fira. GM Is lts biggest cugfomer and the world's largest user - of robots (Greenwald 1985).

GM management has trled to lmpart fts enthuslasm for advanced manufacturing tochnologles to parts suppliers. For example, a 
comunication to suppliers to the Bulck-Oldsaoblle-Cadiliac Division (B-O-C), notes that supplifers are expected to actively institute plans to upgrade technical capabilities and adopt new and appropriate technologies" and "to remain abreast of state-of.the-art technology for the comodities they produce* (B-O-C Document 1986). And in meetings with supplier cop management. $G M$ management has hamered home the need to utilize advanced manufacturing technologies (General Motors of Canada 1986)

Through its media interviews and public announcements, through its actions, and through its direct communications with suppliers. GM management has clearly and consistenty stated its commitment to flexible automation. Because of several industry trends, the $G M$ automation strategy would be expected to be endorsed by part supplier management. One such trend is Increased outsolicing. North American automakers are retreating from vertlcal integration and making ever larger purchases of parts and ssembled components from outside suppliers (Flynn 1987). It has been estimated that by the mid 1990's. GM will be sourcing $60 \%$ to $70 x$ of lts parts from outside suppliers (Courtis 1986). The prospect of winning new business frod GM would be an Incentive for parts suppliers to try please GM.

Just-in-time dellvery. single-sourcling and long-tern contracts between assemblers and suppliers are ocher trends that put pressure on suppliers tocónform to the desands, expectations and noras of thelr. custoners (Jones 1985, Reglonal Industrlal. Expansion 1983). GIven GM's 
exphasis on acthrological stratogy, and given the forces pushing suppliers towards congruence with GM objectives, one would expect top maragement of supplier firms to support investments in new technology. if for no other reason than to please a major cusconer.

\section{I.C.3.Heasures of Adoption Parlabllfty and Response Blas}

To check for rezparse blas and for variabilicy in adoption, I asked 26 GMC purchasing, quality assurance and engineering personnel to rate the 51 suppliers on several criteria. Table 3.2 shows the general. format of the questionnaire given to each GMC respondent. The first four Items in Table 3.2 are used to assess the supplier firms on adoption of advanced technologies and the last two ltems are measures of overall performance.

9 When asked why their firas were adopting fiexible automation, ariy of the plant mangers in the study sald it was to neet custoner expectations. This finding is discussed in greater detall in Chapter Six. 
Table 3.2

- Items in survey of GMC Personnel

In your opinion, compared to lts competitors, the FIRM NAME plant's...

investment in new machinery

and equipment is

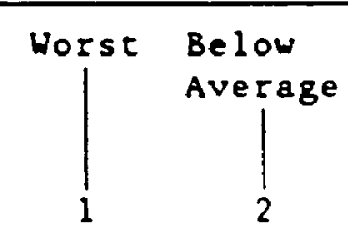

1

2 production equipment is

Average

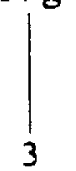

use of state-of-the-art

use of robots, CAD/CAM and

other flexible manufacturing

technologies is .........

use of computers in

manufacturing is

overall performance as supplier

to GH is ................

- chances of being a GM supplier

five years from now is ......

3

Above

Average

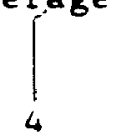

Best

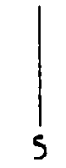

5

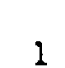

1

2

3

4

5

1

2

3

4

5

1

2

3

4

5

1

2

3

4

5

\section{,}

Table 3.3 presents each plant's mean score on the GMC measures of adoption of automation and of performance, along with the number of . raters who evaluated each plant. Since GMC personnel were asked to rate only those plants, and only on those crlterla with which they wére fanlliar, the number of raters for each plant and for each varlable' differs. "Autoation" is the aean score on the four advanced technology ltems 11 sted in Table 3.2. and "performance" is the mean 
score on the "overall performance" and "future chances" fleas. 10 The GMC ratings will be used lacer in this chapter to test for selfselection bias, but at this point, they will be used to check for varlance in levels of adoption of flexible aucomation.

The plant scores on the GMC measures of adoption of automation ranged from 2.00 to 4.47 , With a mean of 3.22 and a standard deviation of .52 The GMcraters indicated that 26 of the 51 firms had "below average" flexible automation. These statistics would evince that. from the. perspective of GMC personnel, there is variability in adoption: some of the firms in the sample are, and others are not, adopting flexible automation.

aucomator.

$\checkmark$ 
Table 3.3

GMC Personnel Survey Results

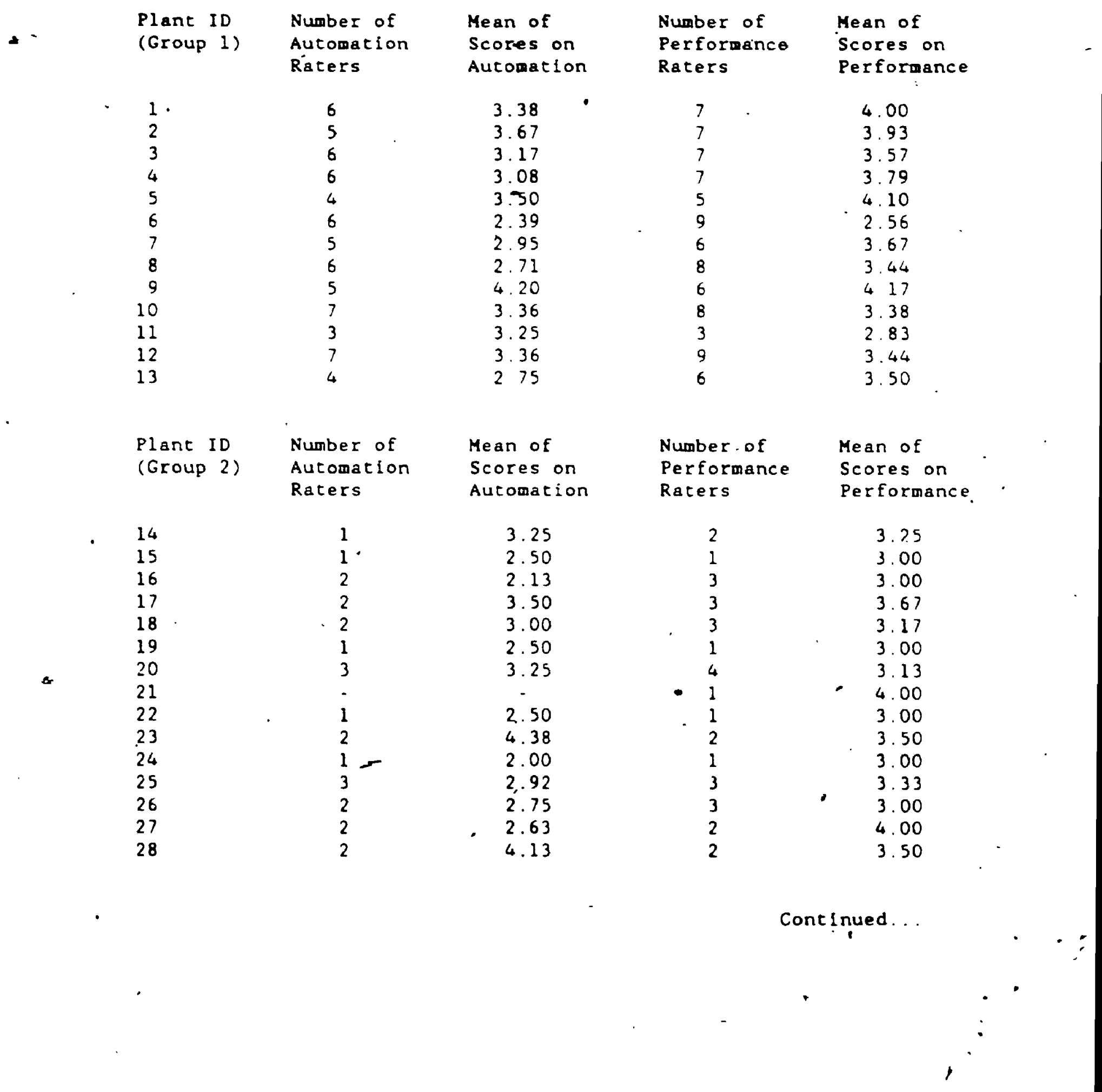


Table 3.3 (Continued)

GMC Personnel Survey Results

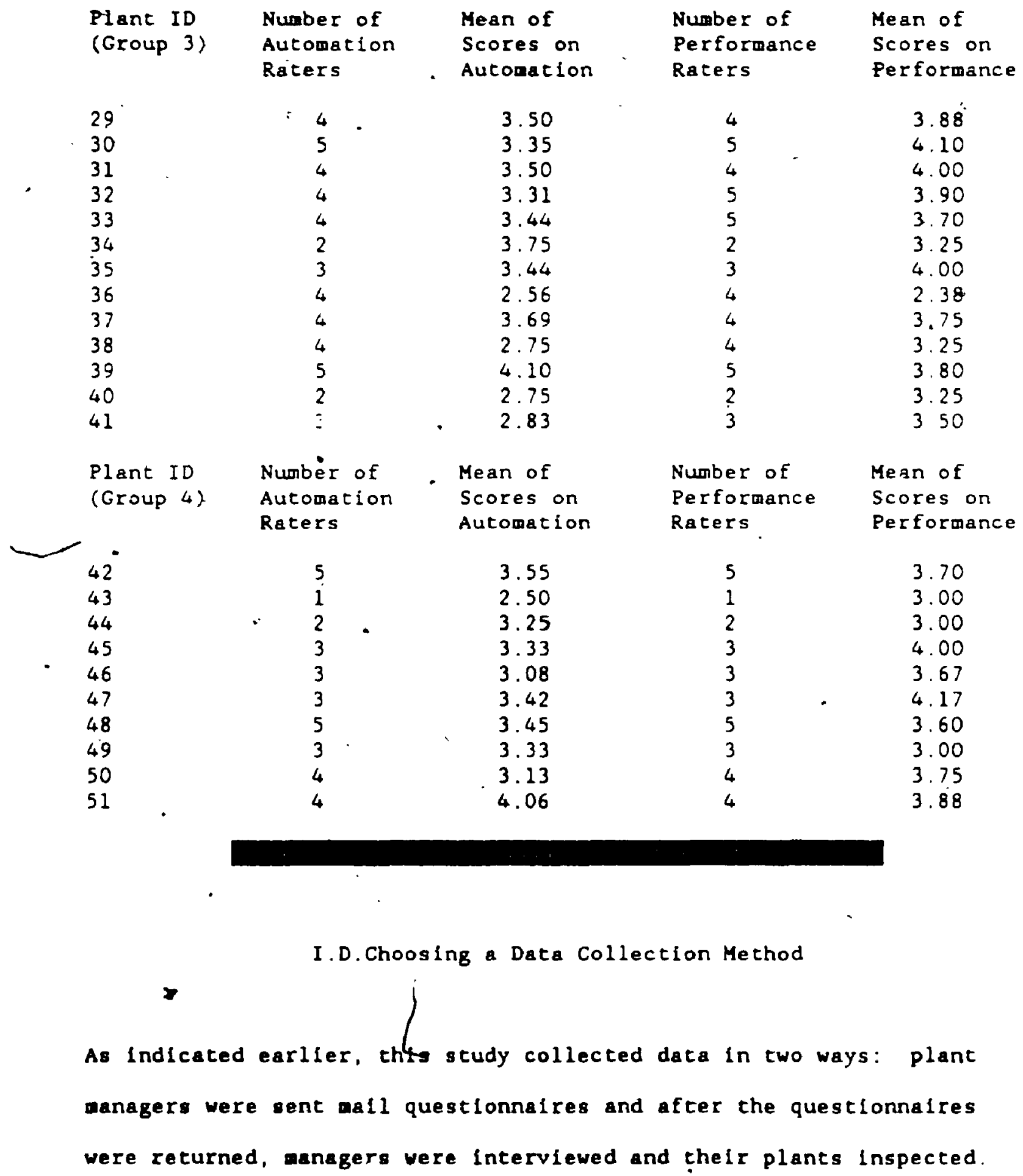


There were several reasons for declding to use a two-wave methodology. To begin with, many of the key varlables $I n$ Models $A$ and $B$ could be messured with both mafl and intervlew instruments. Since personal interviews would be conduited several weeks after the completion of

- mail questionnaires, I expected to get estimates of measurement validity across method and time. There were also some motivational considerations: plant managers would be more likely to return their mail questionnaires knowing I would visit them. 11 Finally, and perhaps most importantly. I was persuaded by the argument that "the external validity iof mail surveys] to be far too low for understanding management accounting phenomena" (Kaplan 1986c). By employing selfadministered questionnaires and Field visits I expected to get a more complete and accurate picture of the role of Macs in the adoption of flexible automation.

\section{Section II: Surveytng suppliers}

The Director of Purchasing for GMC sent top management of each of the 51 Eirms a personal invitation to participate in the study. Appendix B shows a copy of the letter of invitation, and the accompanying information and response sheets. Thlrty-two or $63 \%$ of the firms agreed to particlpate in the study. I contacted as many of the nonparticlpants as possible to find out why they had declded not =o participate. The most often clted reason was plant manager 11 All 32 plant managers In the final sample returned their mall
questionnalies. 
unavallablifty. In one case; the plant manager had recently retired and a new manager had not yet been appointed. In another case, the plant manager was in hospital. In several instances the plant manager was said to be too busy to participate. And finally, one supplier did not participate in the study because, the firm was in the process of being sold.

\section{II.A.Tests of Self-Selection Bias}

There is no evidence of self-selection bias in the final sample of 32 plants. The mean of the GMC personnel survey automation scores of the participating plants was 3.20 and of the non-participating plants. 3.25. A two-tailed test of means showed no significant difference between participants and non-participants on thls "a priori" measure of adoption of automation $(p-.74)$. A similar test on the means of the gim - survey performance scores of the participating plants (3.47) and nonparticipating plants (3.56) also showed no significant difference between the two groups $(p-.51)$.

To check if participation was independent of product group, I performed a Chi-square Test of the contingency table shown in Table 3.4 and found participation In the study was Independent of membership In product group (p-.85). 


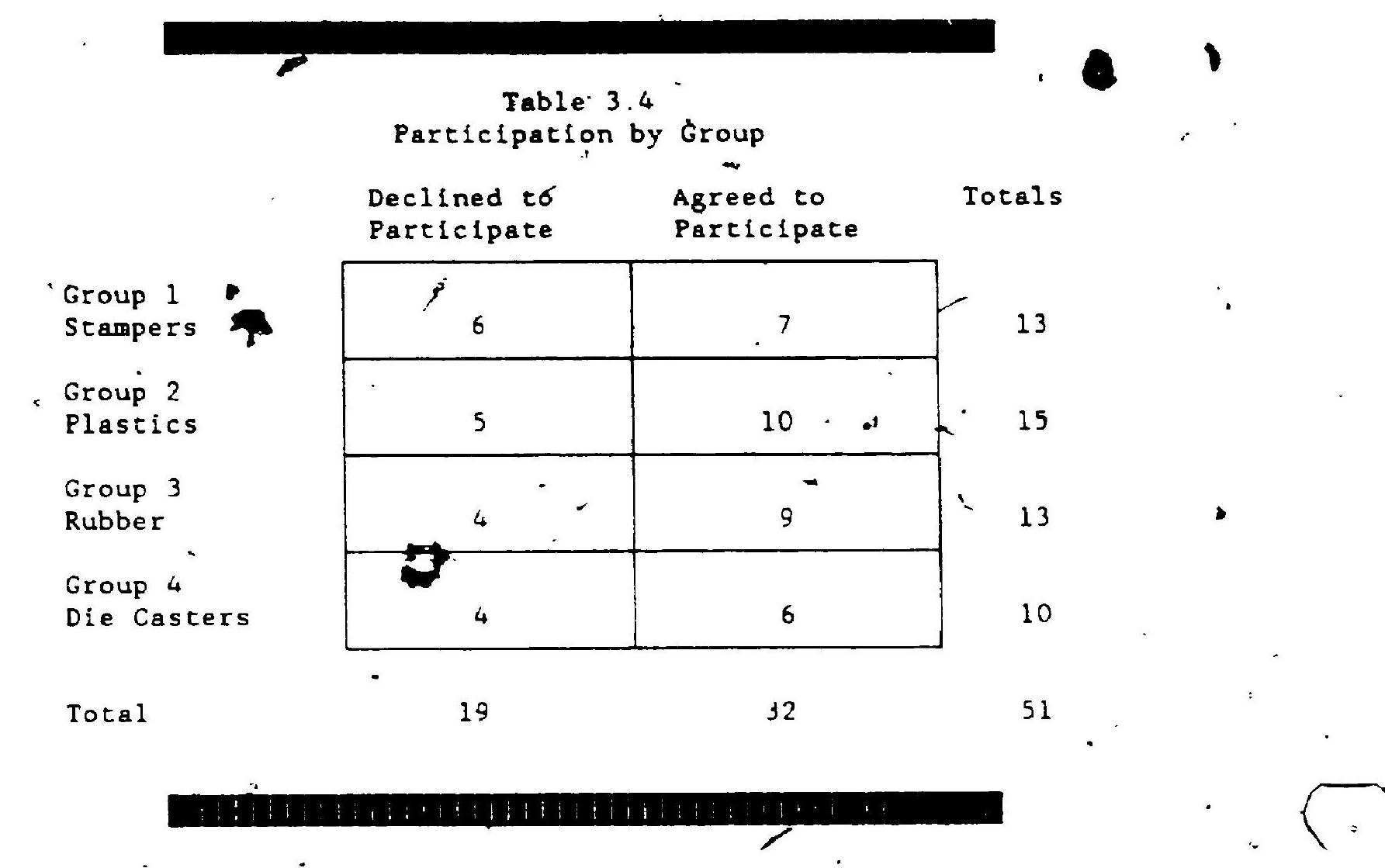

To sum up, on the key variabies of automation and perfortiance, the 32 particlpating plants are representative of the 51 plants in the sampling frame.

II. B. Data Collection Procedures

Table 3.5 summarizes the sceps followed in collecting data for-the study. I have already described the survey of GMC personnel and the invitations senit to the suppliers. and will now describe the mail and personal Interview surveys of the plant managers. 
Table 3.5

Data Collection Process

1. Self-Adminfstered Questlonnalres Completed by GMC Raters

2. Invitations to 51 firms to Participate in study

3. Self-Adminiștered Questionnafres to 32 Plant Managers

4. Face-to-face Intervlews with 29 Plant Managers'.

5. Tours of 24 Planes

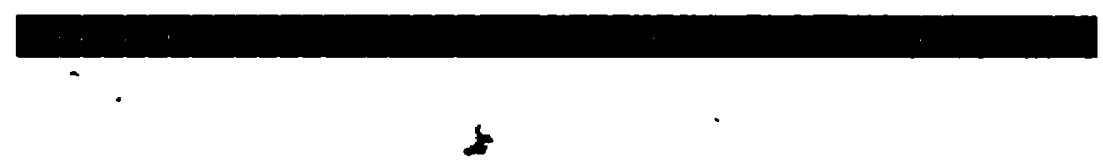

When a supplier returned a response sheet and agreed to participate in the, study, I sent out a package to the person Identified as plant .e manager. Each package included a cdver letter, instructions and a questionnaire: Coples of the cover letter and instruction sheet are presented in Appendix $C$. The questionnaire itself is described in Chapter Four,a Mall questionnalres were typicaliy followed by face-toface interviews of plant managers and tours of their plants. In two instances, ba 11 questionnalres were completed after the face-to-face interviews. In these stuations, the interview protocol, which is also descrtbed In Chapter.Four, was slightly altered to prevent : contanination of the written questionnalre.

From Intelation of the survey of GMC personinel to completion of the plant visits, the data collection procgss stretched out over six. 
months.12 All 32 managers in the final sample returned mall questionnaires, 29 managers were interviewed, and 24 factlities were inspected. Three of the managers who had returned mail questionnaires were not interviewed for the following reasons: top management of one of the supplier firms gave permission for the plant manager to

- participate in the mall questionnalre but. asked that he not be incerviewed, one manager left his job shorty after he returned the questionnaire, and one manager would not combit himself to an interview even after sfx calls Five of the interview sessions were not followed $\therefore$ by plant tours for the following reasons: in three instances the personal interviews took more than 2 hours to complete and the plant managers did not have time to conduct plant tours, and in the other two

The plants in the sample were scatcered along a $1,500 \mathrm{~km}$ corridor between Montreal (Quebec) and Windsor (Ontario). Whenever possible, I tried to arrange visits to several plants in the same vicinity. Typically, I would visti two planţis in one day and spend 2.5 hours at each plant. Half the time would be spent interviewing the manager and the other half tourling the plant. The persional Interviews and plant tours were conducted over a seven week period from late August to midcases the firms had policies that restricted plant tours. October, 1987.

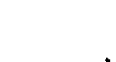


Chapter Four wil detall the Itens in the self-adninistered questionatre and the protocol for the face-to-face interiviews. Before proceeding with the description of the survey instruments. I will present notes on each of the four supplier groups in the sample.

\section{Section IIL: The Four supplier creups}

This section describes general characteristics and manufacturing processes of the four product groups in the sample. At the time of the study, GMC made most of its qajor mechanical components in-house and relled on external suppliets for the production of smaller, mostly decorative parts. Suppliers in the study anufactured parts-ranging in value from a few cents, for small rubber or plastic molded parts, to over $\$ 150$ for assembled components.

The four product groups represent a wide vatiety of processes (mixing. molding, machining, extruding, cutting, painting, plating, assembling) and materlals (aluminum, magnesium, steel, brass, fabrics, a variefy of plastics and rubbers). The groups also represent different, stages of the product iltecycle and different competitive strategles. Stamers were In a acure phase of the product lifecycle. Plants were operated as "cash cows," machlnery was bld, and cost cutelng was emphaslzed. In. contrast, plastic molders and netal die casters were in the growth phase of the product 11fecycle. Sales were increasing. exphasis was on product and process Innovation, and achinery was newer. Plants in the - rubber group were so diverse in product and protess that no 
generalization is possible. More specific descriptions of each group follow.

\section{III.A.Group 1 . Metal Stanpers}

In a characteristic metal stamping plant, metal blanks were cut from large rolls of thin steel strips. The blanks aere scamped into shape by large metal presses and the stamped parts were cleaned and chen. "in some cases, painced, machined or assemblèd (wélded) inco largér components. The stamping process was nolsy and sbimetimes dangerous The presses were usually more than cen years old.but were well maintained and had been upgraded with some automared feature's and safety add-ons. Compared to other parts, dimensional tolerances for stamped parts are not high, though visible parts (such as bumpers) must meet high appearance standards. To reduce costs and assembly work, efforts were being made to redesign parts. For example, rather than stamping two bumper Eomponents and then welding them together, some plants were stamping one-piece bumpers.

III.B.Group 2 - Plastic Molders and Finisiers

Many of the plants ln thls group. nolded agi finlshed plaztic parts, but some plants speclalized in finishing. I will discuss molding first.

Thare are two-besic types of plastic molding. In thermoplastic molding. the raw atérial is mixed in advance and infected into a rold 
where heat and pressure form the plastlc part. In raction-injection solding. two or more different materials are injected into a nold where they undergo a chemical reaction. Thermoplastic aolding is a more forglving process: materlals in scrap and spollage can be recovered. Inportant to both processes is control of factors such as temperature. humidity, and time in mold. And in both process, the molded part must be deflashed. That is, excess materlals must be trimed from the part after it is removed from the mold.

Plaslic finishing includes painting, wétal-plating, and assembling It is afficult to paint or plate plastic products One reason is that plastics cannot tolerate high temperatures, and any of the painting and plating processes require coatings to be "baked" onto the part. Patnting and plating problems are compounded by the fact that finished plastics are "visible" parts ard are expected to have flawless surfaces.

A trend particularly evident in the plastics group was the assembly of parts into modules or syster-. For example, rather than shipping a number of small algnal light components to GMC, some plants were manufacturing and assembling conple ze signal light housings. An. Important issue for firms in the plastlcs group was coordinating production and assembly of several parts within the same plant and wong soter plants. 
- II C.Group 3 - Rubber Parts Manufacturers

Plants in this group manufactured a wide range of products: tires, gaskets, floor nais, tubing, and westher-stripping Most plants mixed thef : own rubber compounds and then wolded (engine wountings), pressed (tires and floor mats) or extruded (door side-moldings) the mixcure into a final form. Rubber molding and pressing processes are similar to plastic molding and metal stamping respectively. In the extrusion process. soft rubber is forced through a die in a continuous process and cut off in required lengths. Like plastic parts, most rubber parts must be deflashed, but unlike most plastics, rubber must be cured.. If plastlc molding is a scfence, laking rubber parts is an art. Rubber manufacturers were reluctant to talk about their art lest they revealed the secrets of theit rubber recipes and curing processes

III.D.Group 4 Decorative and Fupctonal Dịe Casters

In a characteristic die casting plant, a metal (usualiy aluminum) was melted and the molten metal ladled into a mold. Molded parts were cooled and deflashed ind then souetimes machined or assembled. Some of the dle casting plants had unploasant and dangerous environents.

The main difference between functional and decorative die cast parts is that the forwer must weet certaln critical dimevslonal tolerances while the latcar nust also neet hlgh appoarance sandards. A transmisston 
housing is an example of a functional casting and a door handle a decorative casting.

III.E. Opportunities for Automation

VIrtually every process employed by plants in the four groups can be automated. To take plastics as an example, computer-operated equipment can be used to: alx plastic resins, place the resins in molds, control the molding process (heat, pressure, time-in moid), remove parts from molds, deflash parts, paint parts, assemble several parts together and test finished coaponents. DIfferent'plants, even those within the same group and producing the same product, used automation differently.

Things done by robot in one plant were being done manually in another plant and vice versa. However. I can make some generalizations about adoption of flexible automation across the four groups.

In ail four groups, computers were beling used to test product quality. While sophistication of computerlzed inspection and cesting equipment varled, almost all plants had achleved some computerization in this area. 13 Molding of plastic, rubber and metal was another area that wes beconing increasingly automated because equipment manufacturers were automating molding machines. However, while plastic molders and metal die casters were making Increased use of robots to remove parts fron nolds, thls function had proved to be Dore difficult to autonate

13 To help weet high quality standards. North American automitive assemblers have demanded thelr suppliers adopt computerlzed inspection and testing equipaent. 
in rubber plants.' Flpally. one process that was a high priority for autonation in every group was painting. Autrating the painting process iricreased the conslatency of che procedure and protected workers' health. 
CHAPTER FOUK

This chapter explains the operationalization of the constructs in

Model A (relationships'between MACS and adoption) and Model B

(relationships between MACS and adoption with controls for

decentralization). and a number of other constructs that were

considered in the evaluation of those models. The chapter is divided

Into three sections. Section I. presents the mall questionnaire ftems,

Section II discusses the protocol and codings of the face-to-face

Interviews, and Section III sumarlzes the chapter.

-

Table 4.1 lists the main variables used to test the Model $A$ and $B$

Mpotheses. Othis variables that are referred to in Chapters Five and Six are listed in Tasle $4,: 2$ and in Appendices $D$ and $E$.

As shown in Table 4.1, each of the oonstructs in Models $A$ and $B$ have been given a label:

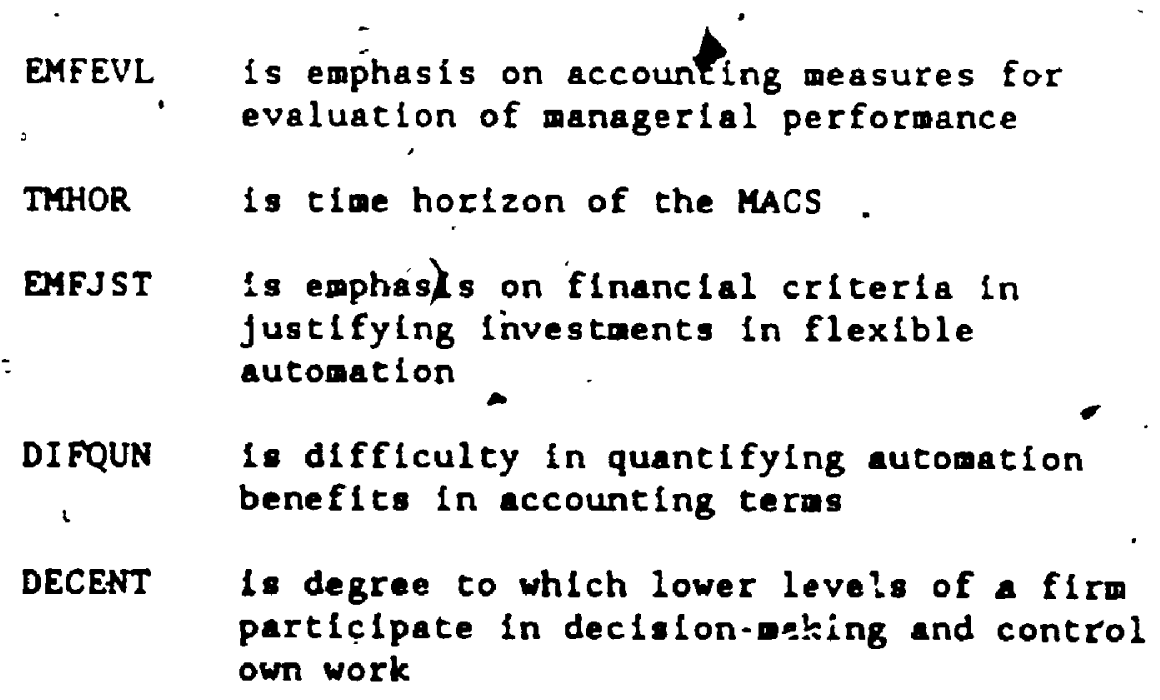


ADOPT Is level of adoption of flexible automation

The Instruments used to tap the constructs are identified by labels and by numeric and alphabetic suffixes. The numeric suffixes differentiate among measures of a construct. In some cases, multiple measures are indicated because there is more than one established instrument associated with a construct. In other cases, the use of several measures reflects the multidimensionality of a construct. The - lphabetic suffixes refer to method of data collection:

$G$ - indicates a variable from the survey of General Motors of Canada (GMC) personnel

$M$ - Indicates" a variable from the Hail survey of plant wanagers

F - Indicates a variable from the Face-to-face interviews of plant managers

Thus, ADOPIM refers to a mail questionnaire measure of adoption and ADOP2M refers to a different mail'questionnalre measure of adoption. $A D O P 2 G$ is the same Instrument as ADOP2M, but whereas ADOP2M is a plant manager mail survey measure, ADOP2G is a GMC personnel survey measure. And.. as wili be explained later. ADOPGFM is a ratio with a nuperator. from the face-to-face interviews and a denominator from the mail questionnaires..

In Table 4.1, the numbers under the heading "Table" refar to the tables In thls chapter which deplct the all questionnaire ltems. The face- 
to-face variables are registered in Appendix D (Interview Protocol) and Appenil $\times E$ (Interview Coding Sheet).

The references listed under "Sources" In Table 4.1 specify versions of the instruments used in the study. For example, DECENT2M is a measure of decentralization suggested by Hage \& Aiken (1967) and refined by Dewar et al. (1980). Only Dewar et al. are clted in Table 4.1 because their version of the instrument is used in the study. Measures specifically desfgned for this study, are indicated as being "New."

The number of items in each measure and the procedure used tongentace a scale from the items is indicated under the Table 4.1 heading. "Scale/Items." In most cases, variables were created by suming the.

- scores on the ftems of a measure. The number of ftems, possible scores on each ftem, and the procedure used to generate a scale. determine the range of each measure as reported in.the last column of Table 4.1. For example, EMFEVL2M has four items and each item can have a score between 1 and 5 inclusive. Since EMFEVL2M is the sum of the scores on the four Items, the varlable can range between 4 and 20 . 
Table 4.1

Main Variables in Models $A$ and $B$

\begin{tabular}{|c|c|c|c|c|}
\hline $\begin{array}{l}\text { Construct Name } \\
\text { and Definition }\end{array}$ & Table & $\begin{array}{l}\text { Instrument Name } \\
\text { and Source }\end{array}$ & $\begin{array}{l}\text { Scale } \\
\text { Items }\end{array}$ & Range \\
\hline \multirow{4}{*}{$\begin{array}{l}\text { EMFEVL } \\
\text { emphasis on } \\
\text { accounting } \\
\text { measures for } \\
\text { performence } \\
\text { eviluations }\end{array}$} & 4.2 & $\begin{array}{l}\text { EMFEVIIM } \\
\text { Brownell \& Hirst }(1986)\end{array}$ & $c * 1$ & $1-4$ \\
\hline & - & $\begin{array}{l}\text { EMFEVLIF } \\
\text { Interview version of EMFEVLIM }\end{array}$ & $c$ & $1-4$ \\
\hline & 4.3 & $\begin{array}{l}\text { EMFEVL2M } \\
\text { Merchant (1981) }\end{array}$ & $S$ & $4-20$ \\
\hline & 4.4 & $\begin{array}{l}\text { EMFEVL3M } \\
\text { Merchant (1981) }\end{array}$ & S 10 & 10.50 \\
\hline \multirow{4}{*}{$\begin{array}{l}\text { TMHOR } \\
\text { time horizon } \\
\text { of accounting } \\
\text { measures }\end{array}$} & 4.5 & $\begin{array}{l}\text { TMHORIM } \\
\text { New }\end{array}$ & 3 & $3.2 \overline{0}^{\circ}$ \\
\hline & 4.5 & $\begin{array}{l}\text { TMHOR } 2 M \\
\text { New }\end{array}$ & 3 & 3.20 \\
\hline & 4.6 & $\begin{array}{l}\text { TMHOR 3M } \\
\text { Cook }(1986)\end{array}$ & A 1 & Open \\
\hline & . & $\begin{array}{l}\text { TMHOR3F } \\
\text { Interview version of TMHOR } 3 \text { M }\end{array}$ & A 1 & Open \\
\hline \multirow{2}{*}{$\begin{array}{l}\text { EMFJST } \\
\text { emphasis on } \\
\text { financial } \\
\text { criterio in } \\
\text { justification. }\end{array}$} & 4.7 & $\begin{array}{l}\text { EMFJSTIM } \\
\text { New }\end{array}$ & $s$ & $4-20$ \\
\hline & - & $\begin{array}{l}\text { EMFJST2F } \\
\text { NeW }\end{array}$ & $\begin{array}{ll}c & 1 \\
\cdots & \end{array}$ & 0.2 \\
\hline $\begin{array}{l}\text { DIFOUN "i : } \\
\text { difficulty in } \\
\text { quantification }\end{array}$ & $=4.8$ & $\begin{array}{l}\text { DIFQUN!M } \\
\text { New }\end{array}$ & $s$ & $6-30$ \\
\hline \multirow[t]{2}{*}{$\begin{array}{l}\text { DECENT } \\
\text { decentral - } \\
\text { ization }\end{array}$} & 4.9 & $\begin{array}{l}\text { DECENTIM } \\
\text { Schroeder (1981) } \\
\text { Marshall (1985) }\end{array}$ & S 15 & 15.75 \\
\hline & 4.10 & $\begin{array}{l}\text { DECENT2M } \\
\text { Dewar et al. (1980) }\end{array}$ & s & $5 \cdot 20$ \\
\hline
\end{tabular}

* C-coded response, S-sum of 1tems, A-actual response, M-mean of 1 tems 
Table 4.1 (Continued)

Main Varlables in Models $A$ and $B$

\begin{tabular}{|c|c|c|c|c|}
\hline $\begin{array}{l}\text { Construct Name } \\
\text { and Definition }\end{array}$ & Table & $\begin{array}{l}\text { Instrument Name } \\
\text { and Source }\end{array}$ & $\begin{array}{l}\text { Scale } \\
\text { Items }\end{array}$ & Range \\
\hline \multirow{6}{*}{$\begin{array}{l}\text { ADOP } \\
\text { adoption of } \\
\text { flexible } \\
\text { automation } \\
\text { techrologies } \\
\text { at plant } \\
\text { level }\end{array}$} & 4.11 & $\begin{array}{l}\text { ADOPIM } \\
\text { Cook (1986) } \\
\text { Several industry surveys }\end{array}$ & $5 * 8$ & $8 \cdot 32$ \\
\hline & -3.2 & $\begin{array}{l}\text { ADOP2M } \\
\text { New }\end{array}$ & $M$ & $1-5$ \\
\hline & 3.2 & $\begin{array}{l}\text { ADOP } 2 G \\
\text { GMC survey version of } A D O P 2 G\end{array}$ & $M \quad 4$ & $1-5$ \\
\hline & - & $\begin{array}{l}\text { ADOR3F } \\
\text { Cohn \& Turyn (1984) }\end{array}$ & $A$ & Open \\
\hline & $\cdots$ & $\begin{array}{l}\text { ADOPGFM } \\
\text { Created by dividing ADOP } 3 F \\
\text { by number of plant workers }\end{array}$ & & - \\
\hline & - & $\begin{array}{l}\text { ADOP } 5 F \\
\text { New }\end{array}$ & C 1 & $1 \cdot 5$ \\
\hline
\end{tabular}

* C-coded response, S-sum of ltems, A-actual response, M-mean of liems

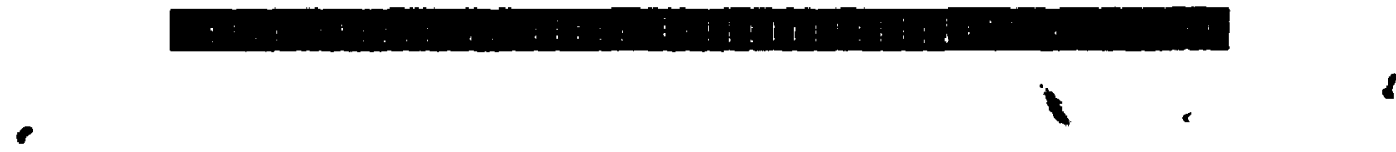

The mall questionnalre and the interview protocol were critiqued by several colleagues', but for the following four reasons, it was thought unnecessary to pretest the instruments on a sample of plant managers. First, many of the Instruments used in the study have been tested and used in previous studies. Second, respondents to the mail questionnalre were encouraged to seek clarification of confusing items at the follow-up meeting with the researcher. Third, because of the length of Hme between mall questionnalre responses and face-to-face Interviews, wall questionnsire data could be anaiyzed, shortconings 
identified, and problems addressed in the follow-up interviews. Finaliy, conducting a pre-pst on even a small fraction of the sample would have severeiy reduced the power of the statistical tests used to test the hypotheses.

Section I: The Mail, Questionnaire

In Chapter Three, I described the procedures followed in administering the mail.questionnaire to the 32 plant managers. Copies of the introductory letter and instruction sheet that accompanied each questionnaire are shown in Appendix $C$. In this section, I will present the actual mail questionnaire instruments.

.I.A: EMFEVL (EMphasis on accounting For EValuation)

There are three mail questionnaire measures of EMFEVL: EMFEVLIM, EMFEVL2M and EMFEVL3M.

EMFEL2M and EMFEL3M.

EMfEvila is Hopwood's $(192)$ measure of supervisor evaluation sityle. Hopwood gave cost centre hedds of a large manufacturing flrm 11 sts of eight criteria that might be used to exluate their performance. He asked respondents: "What do you think counts the bost in how your departmental supervisor evaluates your performance?" Among the

crlterla were "concern with costs" and "meetling tho budget." Hopwood - (1972) classified evaluation givle into four categortes: 

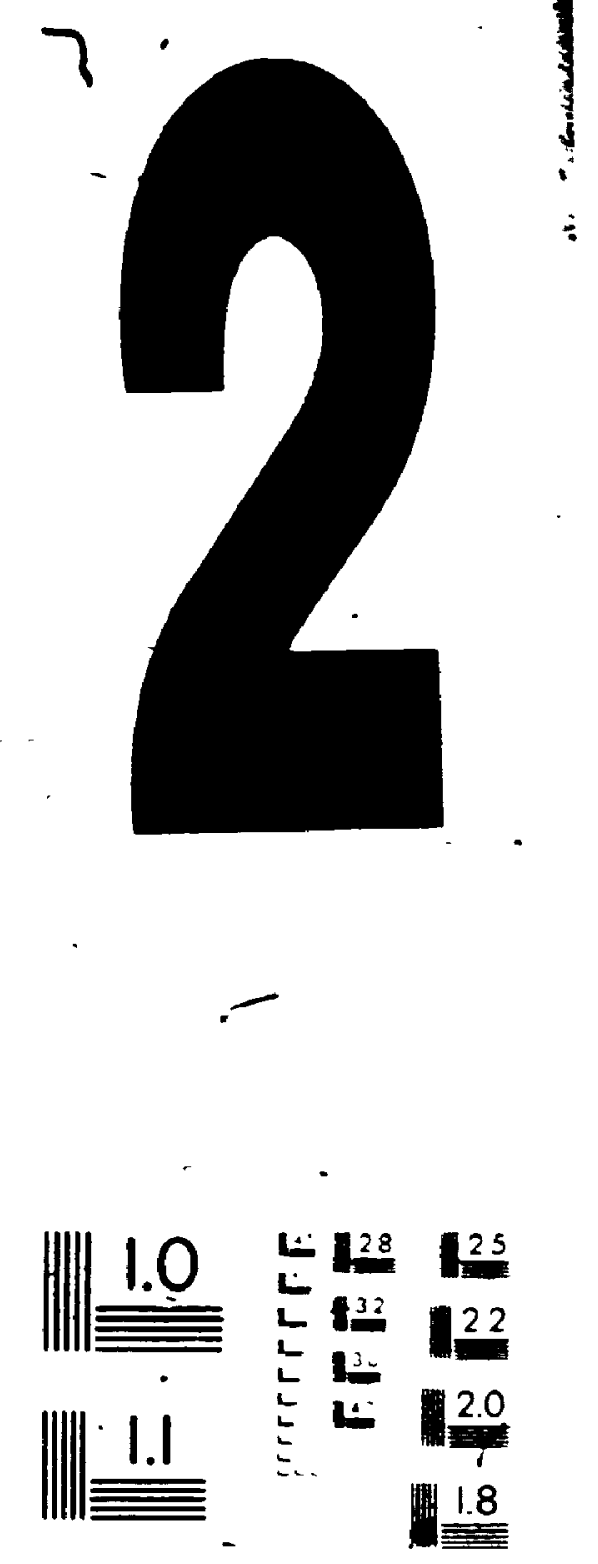

$\||| 1.25$

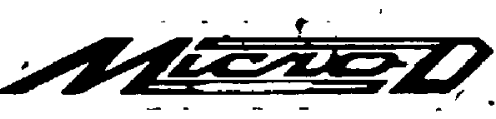


1. Nonaccounting style:

2. Profit Conscious style:

3. Budget-Profit style:

4. Budget Constrained style nefther weeting the budget nor concern with costs ranked anong the top three criteria.

concern with costs, but not weeting the budget. ranked anong the top three criterla.

both neeting the budget and concern with costs among the top three crlterla

neeting the budget, but not concern with costs, ranked among the top three criteria

There is an implied ordinal scale underlying this classificatons scheme, with Budge - Constrained style at one end of the scale and Nonaccounting style at the other (Otley 1978). In a Budget Lonstrained situation, accounting measures of performance influence all aspects of the behaviour of a manager and his/her supervisor. In a Profit Consclous situreion, managers and their superiors use accounting measures for problem-solving, and managers are evaluated on financial and non-financial criteria. In a Nonaccounting situation managers are evaluated on non-financial criteria.

Hopwood's measure has been used by Otley, (1978), Brownell (1982), Brownell \& Hirst (1986) and Govindarajan (1987). For this study, I slightly modifled the Brownell \& Hirst (1986) vertion. Because I was dealing with number of different companfes and could not be sure of the completeness of the $11 \mathrm{st}$ of criteria. I added a line for respondents to wrice in criterla not included in the quegtion. I also changed the ftem "cooperation with individuals outside the firm" to 
read "keeping custoners happy." Table 4.2 presents the final form of the weasure.

The ceding of responses to EMFEvLlM follows Hopwood (1973), except chat Instead of coding the top three criteria in each response, I followed Brownell \& Hirst (1986) and coded the top four. The inclusion of the fourth ranked criterion in the coding is justified by the Increase in the number of criteria considered (Brownell \& Hist 1986). To

- Illustrate, if a respondent ranked budget but not cost as one of the - Eour most important criteria in his evaluation, his response would be classified in the Budget Constrained category and be coded as a " 4 " A scare of :"3" Indicates a Profit-Budget Style, a "2" is a Profit Style and " $1 "$ " is a Nonaccounting Style. A higher score on EMFEvLlM Indicates that a plant manager's supervisor places more emphasis on accounting aeasures in the evaluation of the manager's performance.

$\bullet$
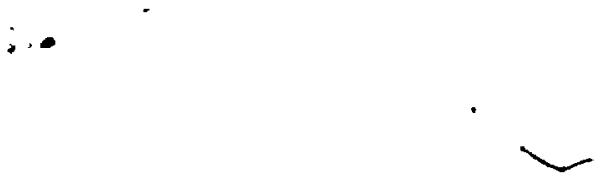

1

$\checkmark$ 


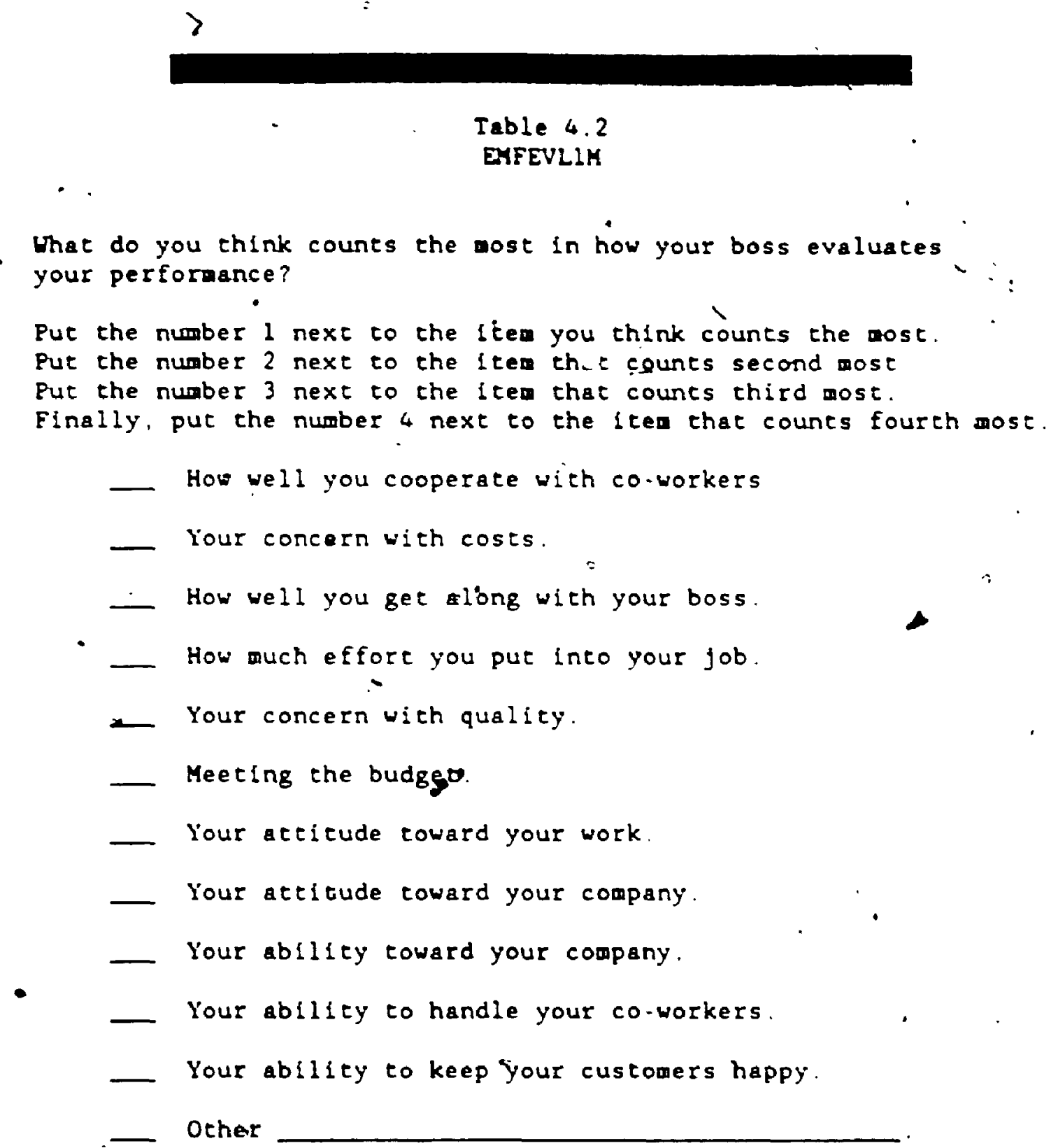

There are two problems, with EMfEvLIM. The first problea is Interpreting the Nonaccounting Style. Forty-four percent of the aubjects in Hopwoad's (1972) sudy were classlfled in the Nonaccounting 
Table 4.3

BAFEVL2H

Listed below are number of activities related to your fob and use of budgeting. Please indlcate how often each activity takes place.

Never Rarely Sometimes Often Always

I am required to submit an explanation in writing about causes of large budget varlances

I am required to repore actions I cake to correct causes of budget variances.

I am required to prepare reports comparing actual results yith budget.......

I an required to trace the caude of budget pariances to groups or individuals wt thin

1

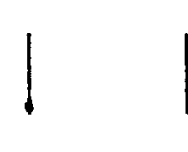

12

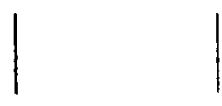

2

2

$\checkmark$

1

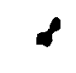

1

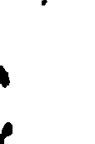

2

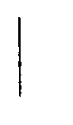

3

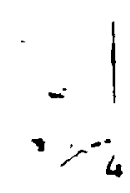

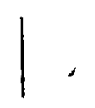

5

3

$4 \quad .5$

2

3

4

5

The 10 items in EMFEVL3M teasure extrinsic and intrinsic motivation to score well on accounting messures of performance (Hackman \& Porter 1968, Dermer 1975. Merchant 1981). The first 7 f tews in EMFEVL3M measure the extent, to which budgeting systems are linked to corporate rewards and the last 3 it tems meature che extent to whlch budget $\because=$

"- performance is linkied to personal satisaction. I Justify cosbining l... the extrinsic motivation measure with meagure of Intrinsic motivation because Derver (i975) concluded the two constructs are corequisites and 


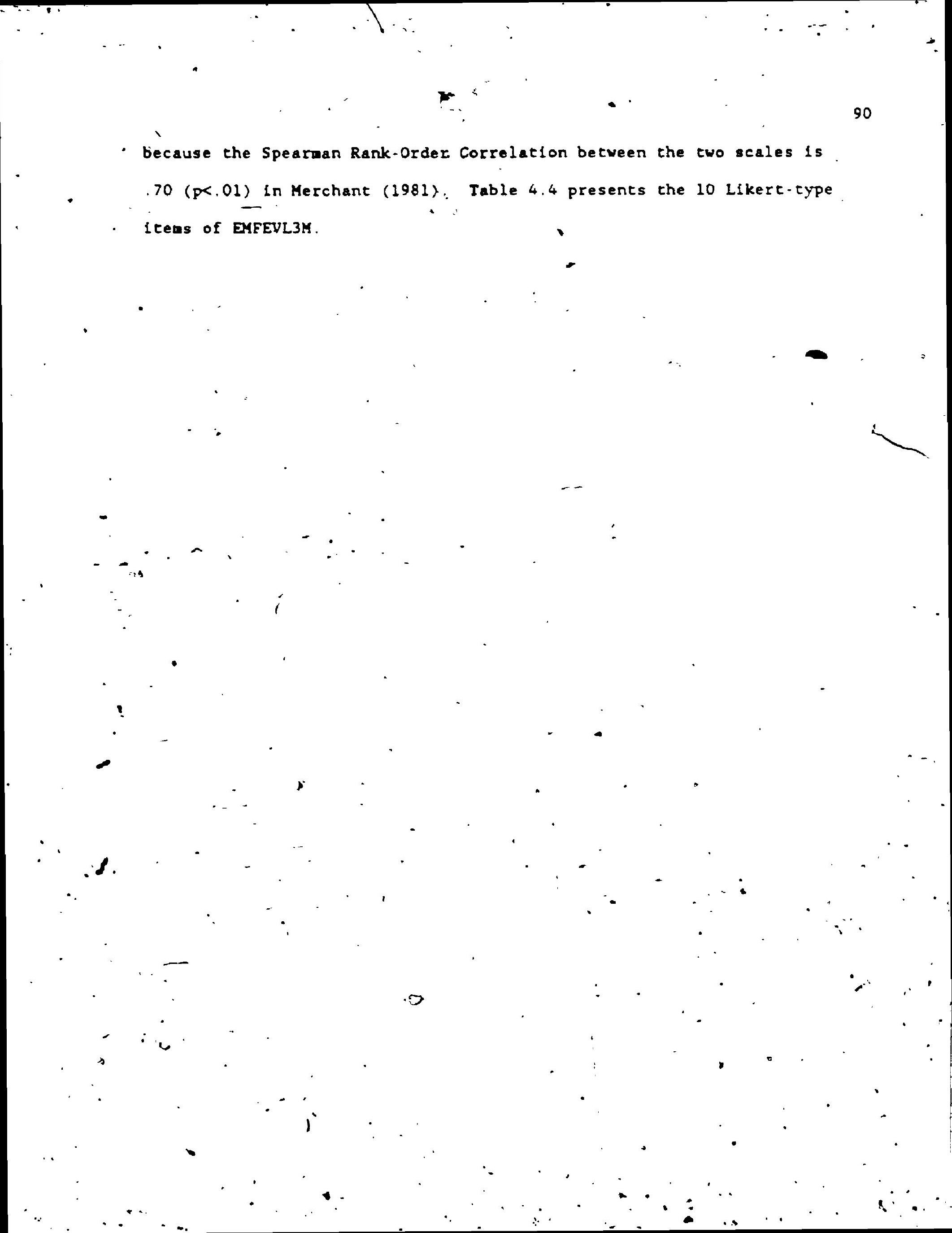




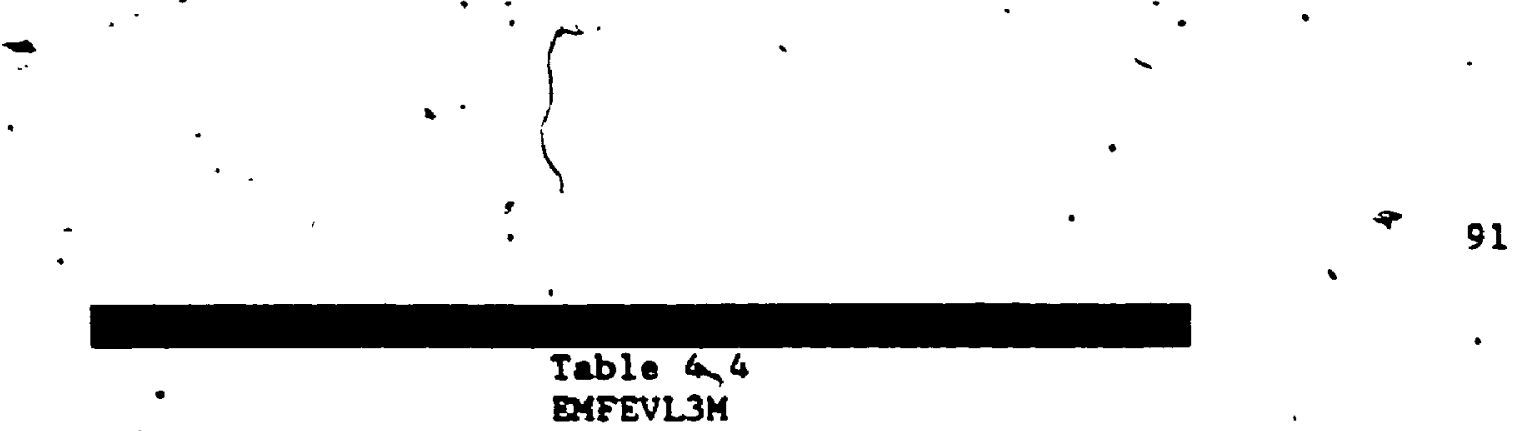

Please circle one number for each of the following statenents about budgets and budgeting in your company.

Budget performance is

$$
\text { Strongly }
$$

Disagree

an Importan Eactor

in advancing my career.... 1

12

2

If I exceed budget

targets I will get

more responsibility....... 1

2

2

3

4

5

My job security will

improve if I consistently

meet budget targets,$\ldots .$.

1

2

3

4

Strongly

My pay increases are closely

tied to budget performance. 1

2

3

$4 \therefore$

5

My talents will be betcer

recognized if I metet my

budget targets.......... 1

I will have better relations

with my boss if I perform well

in relation to the budget.. 1

Other managers will thinl

more highly of me if I

perform well in relation

to the budget.......... 1

2

3

4

5

I get a great.sense of

personal gatisfaction when.

ay perforaance compares

favorably with the budget..

Good performance on budget

targets glves we a feeding

of eccompl Ishment. . . . . . .

Manaiging to achleve budget

targets contributeg: to ay

perconal growth arto

development............. 1

2.

3

4 
I.B. MAHOR (TIMe HORIzon of accouniting systen)

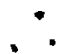

Three mall questionnafre tems Measure MMHOR. 'MHORIM and MHOR2M deal with the time horizons of performance measurement and reward systems while mHOR3M measures the payback erlterla used to screen capital budḡeçing proposals. I will first discuss TMHORIM and MMHOR2A, and then TMHOR 3H.

Lorsch \& Morse ( dimension of formal practices." They asked respondents to indicate the time span of their business whit's formal performance review, the time. span of 1 ts shortegt reporting period, the range of time over which its employees sould comit resources and 1 es throughput tor: "Calling the

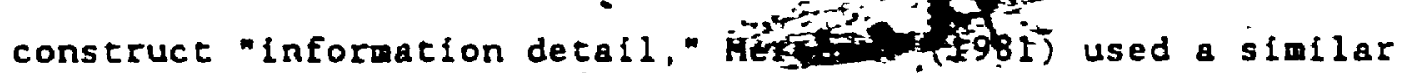

Instrument to measure the smallest block of time for which accounting reports are prepared. In this study, I asked respondents to indicate the time spans of budget targets, budget reports, and formal reviews of performance. Because firms typically have mulclple targeț, reports. and performagce reviows. I asked respondents tc indicate the time perlods of all targets, reports and formal reviews. To give managers a - focus for thele responses,. I defined budget targets and reports. Table 4.9 shows the three 1 teas in TMHORIM and MHOR2M. The lowest numbered response to sach of the three. Itens were sumed to for the ThHORIM variable and the highest numbered response to each of the three Iteps 
were sumed to form MHOR2M. 1 Thus, MHORIM and MAHOR2M say be

interpreted respectively as measures of the short-term, and long-term

tiut horizons of the MACS.

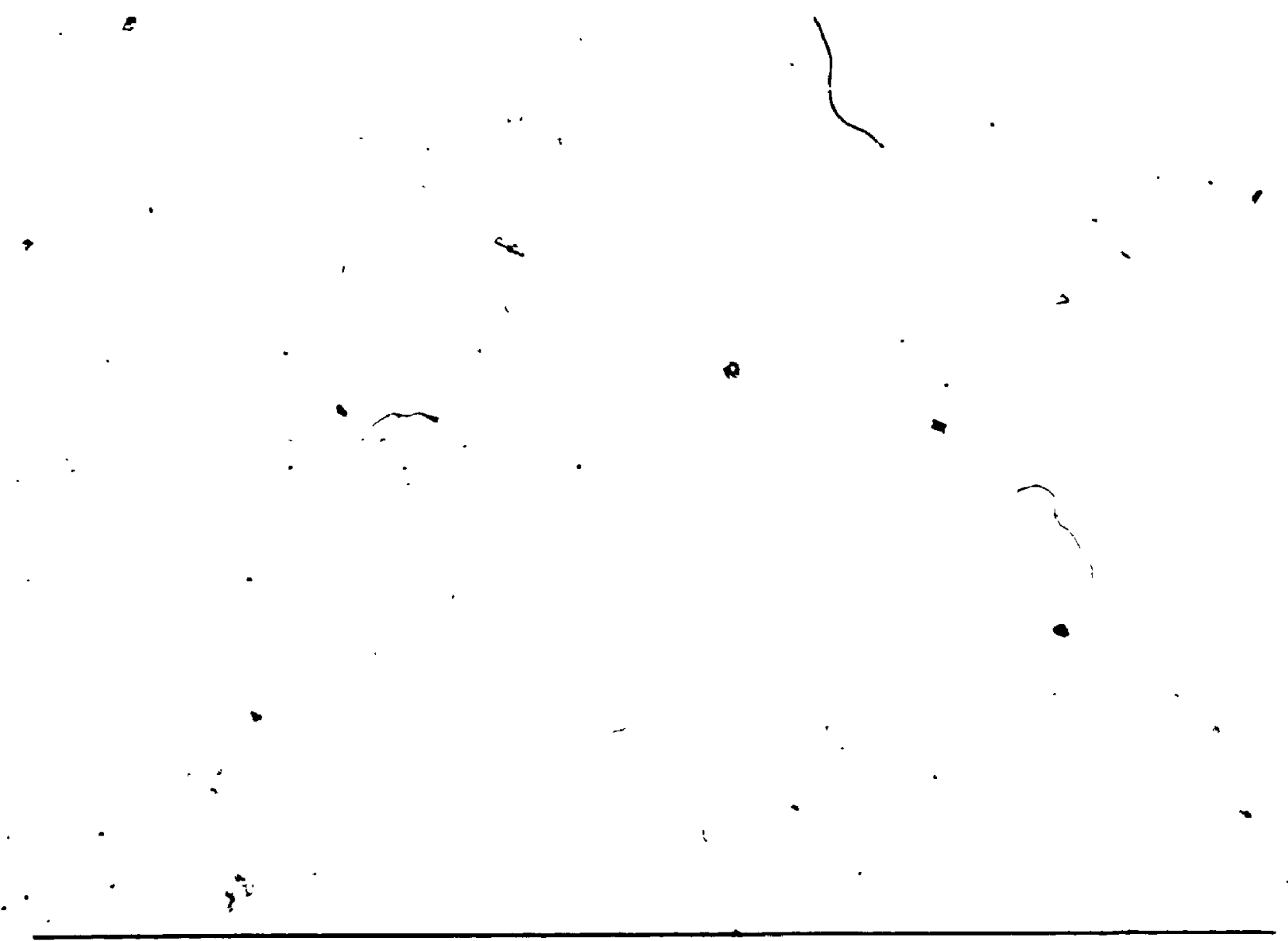

1 If only one number waś circled for any response, that number was used for both MHORIM and MHOR2M. Respondents who did not have budget tarigets: reports or formal evaluations were not included in the TMHORIM and THOR2M analyses. However, as discussed later, the edoption levels of these respondents were investigeted. 

distant future has practically no significance to the decision-maker $\ldots$, who uses present value calculations." A slailar argument can be made for payback criterla (Pike 1993). Higher hurdle rates and shorter required paybacks for proposed Investments are expected to shorten managers' time horizons.

The icems in Table 4.6 were adapted from Cook (1986). Interestingly. almost every manager indicated that capital Investments were not required to meet rate of return or hurdle rate criteria. This ratule was confirmed in the face-to-face interviews. Plant managers were not using discounted cash flow methods to analyze projects. Though, in some cases, more sophisticated methods were used by corporate level staff, plant managers themselves used only payback criterla to assess potential investments. 2 Therefore, only the two payback items of Table 4.6 are relevant to this ștudy. When managers indicated they used different payback criteria for investments in flexible automation, that response was used. Otherwise. TMHOR3M represents the "all purpose" payback criterion. ${ }^{3}$

2 In many cases plant managers were unfamiliar with the discounted cash flow technique and had no idea if anyone in their firm used the technlque. In the few cases where managers were familiar with the technique and knew that "someone at head office" calculated each proposal's net present value or internal rate of return, they did not know or would not say what the discount or hurdle rate was.

3 As discussed in Chapter Two, Hoods ot al. (1985) found that some Firms used one set of criterla and evaluation cechnique for assessing investments in regular equipment and another set for advanced technologies. 
Table 4.6

TMHOR 3 M

Are capital investments in your plant required to exceed a certain rate of recurn or hurdte rate? (Circle number.)

1 Yes $\ldots$.. What is the hurdle rate? $x$

2 No $\cdots>$ (Please skip next question.)

Are some capital investments in flexible automation required to meet a different hurdle tate than other investments? (Circle number.)

3

1 Yes ... What is the hurdle rate for flexible automation? z

2 No

is

Is there a required payback period for capital investments in your plant? (Circle number.)

1 Yes... what is the required payback? _yeags

2 No $\cdots$ (Please ;skip next question.)

Are some capital investments in flexible automation regquired to meet a different payback period than other investments? (Cfrcle number.)

1 Yes...$>$ what is the rogytred payback for flexible automation? years.

2 No

1

I.C.EMFJST (EMphasis on Financlal JuSTification of automation)

I.D.DIFQUN (DIFflculty in QUaNtifylng benefits of automation)

There are no establlshed messures for EMFJST and DIFQUN, so instruments were developed to tap these two constructs. The neasure, EMFJSTIM. 
displayed in Table 4.7, asks respondents to agree or disagree to four statements declaring that approval of investoents in new equipment deperids on financlal issues. DIFQUNIM is a six iten Instrunent that asks respondents their opinion on how difflcultit is to estimate the doliar value of automation benefits and the extent to which automation costs are easier to escimate than benefits. DIFQUNiM is presented in Table 4.8. Scores on the first item of DIFQUNiM were reversed. $\because$.

The items in EMFJSTIM and DIFQUNIM reflect issues raised in the literature reviewed in Chapter Two. Because these measures are new. special effort was made in the face-to-face interviews to get a sense of the importance of financial justification to the approval of flexible automation projects and the difficulty in quantifying automation proposals in financial terms.

$v$

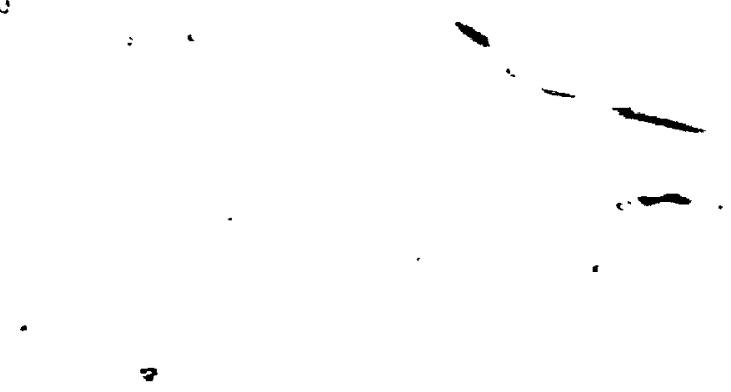



Table 4.8

DIPQUNIM

Here are some stacements about estimating the costs and benefits of flexible automation. Think of the situation in your company when you circle one number for each statement.

It would be easy to

estimate the benefits of

flexible automation in

dollars

If you play around with.

cost and revenue esfimates.

you can make any investment

in new equipitent look good

Strongly

Strongly

Disagree Disagree Neutral Agree Agree

It would be hard to estimate

the costs of flexible

automation ...........

$\cdot 1$

2

3

4

5

Usually, top management is susplclous of estimates of

the financial benefits in

proposals to buy new equipment

1

2

3

There is lots of flexibilicyi

in what costs and benefits can

be Inclüded in a proposal to

Invest in new equipment...

$\therefore$

Top management expects

managers to underestimate the costs of investaents in new equipment ............
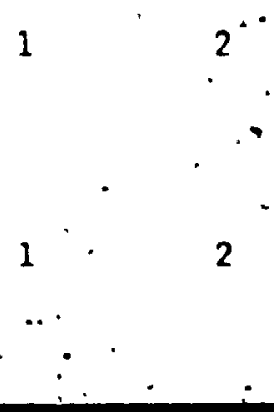


\section{I.E.DECENT (DECENTralization)}

Centralization has been defined as the "extent to which the locus of authority to aake decisions affecting the organization is confined to the higher levels of the hierarchy" (ChIld 1973). The construct

"centralization" and lts complement. "decentralization" have figured prominently in both inrovation and accounting literatures. Fot the sake of consistency, I wll use the term "decentralization" rather than "centralization." recognizing that the terms represerit opposite ends of the same scale. ${ }^{4}$

Three different measures of decentralization were considered for this study. Accounting researchers have typically used the abbreviated Aston messures (Pugh et al. 1968, Inksion et al. 1970), while many innovation researchers have employed the Aiken \& Hage instruments (Dewar et al. 1980). Recently, several innovation studies have used a "key informant eype of methodology" (Marshall 1985). I will discuss each of these three measures of decentralization.

-The Astón Instrument presents subjects with a list of 23 standard declsions and asks them to indicate the level of the organization at which those decislons are made. Varlations of the Aston measure have been used by Bruns Haterhouse (1975), Merchant (1981) and Chenhall Mortle (1986). The Aston Iristrument was thought to be Imappropriate

4 To restate Chlid (1973), decentralization is defined as the extent to which the locus of authorlty to make declsions affecting the organizition is confined to lewer levels of the hiorarchy. 
for this study because few of the 23 standard decislons relate to the Investment decision per se. As well, because of the varlety of firms - In the sample, it would be difficult to construct meaningfil labels for equivalent hierarchical levels at wich declsions are ade.

In the key informant instrument, respondents are presented with a list of common activities and asked to state the levelo of the organization responsible for waking declsions about, those activities (Zmud 1982. Marshall 1985). The key informant instrument differs from the Aston measure in that activities and hierarchical levels are more closely tallored to respondents Using a-key informant approach would provide a deciston list wore relevant to plant managers and the adoption process, but it wold not solve the problem of finding meaningful and equivalent hierarchical levels.

There are two Alken \& Hage measures of decentralization: one caps decentralization of declsions about organizational resources and the other taps decentralization of work control. The firsi measure. "decentralization of decisions," lists four standard decisions and asks, not at what level each decision is aade, but how frequently rcspondents participate in those decislons. The scale is this a measure of the respondents partelpation in declston-making. The second instrument, whlch has also been called "hlerarchy of authorlty" scale, is a five ited measure of the respondents' perceptlons of the control they have over thelr own jobs. 
Pugh et al. (1968). claid that the Alken's Hage instruments are "too perceptual" or subjective. Closely related is Marshall's (1985) concern that scores on the particlpation scale are dependant on who the respondents are, or more precisely. on the respondents' hierarchical posftions in their organizations. My own concern with the participation scale is that the type of declsions listed in the instrument are Inappropriace to a manufacturing setting 5

In this study, decentralization was operationalized by two instruments. one to measure decentralization of decision-making (DECENTIM) and one to measure the degree of job control (DECENT2M). DECENTIM combines features of the Aston, key Informant and Aiken \& Hage participation measures. DECENTIM lists a number of tactical and strategic. Manufacturing-related decisions and asks respondents how frequently they participate in those decisions. The Ilst of decisions in DECENTIM comes from schroeder (1981) though simllar lists can be found in other operations management texts.

DECENT2M is a slightly modifled version of the Alken \& Hage inierarchy of authorlty" or "decentralization of wor control" scale (Dewar et al. 1980).

The DECENTIM and DECENT2M measures are presented In Tables 4.9 and 4.10. To be conslstent with DECENTIM, the scores on DECENT2M were

5 The four declelone listed in the Alken Hage participation scale are: hiring now staff, provoting profoselanal eteff, adopting new policles and adopting thew prograns (Hage o Alken 1967). 
103

: reversed. A high score on either of the two measures indicates a - decentralized organizational structure.

Because this study surveys only one manager from each firm, the validity of the decentralization measures rests on the assumption that the managers in the sample are. from approximately equivalent hierarchical levels. If respondents are Er different levels,. decentralization scores fay convey wore information about respondent position thar organizational structure. For this season. respondent position was assessed in the face-to-face interviews. The measurement and impact of respondent hierarchical level are discussed in Chapter Five in the context of the validity of the DECENT measures 



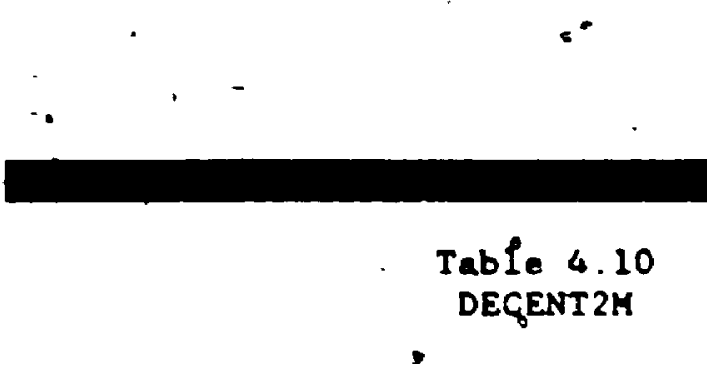

Here are few general statements about how declsions are aade in some companies. How true is each statement about your company? (Circle one number for each atement.)

There can be little

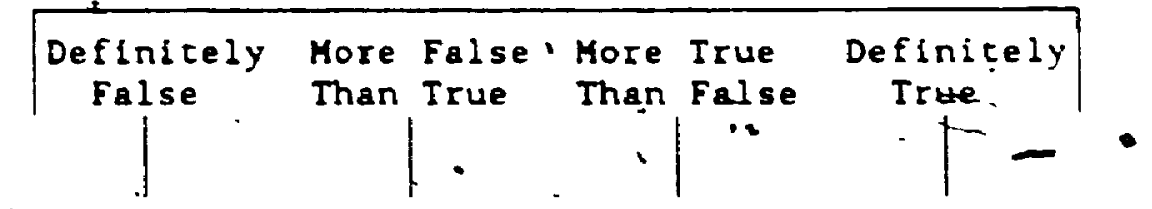
action taken here until a supervisor approves the decision. 1 1

People who want to make their own decisions would to quickly discouraged here ................

Even small matters have

to be referred to

- someone hIgher up for a final answer ........

In this company people have to ask theli bosses before they do almost anything 1 1 1 2 3

Every decision has to have a mervlsor's approval 1 2 3 4

Table 4.10 DEĢENT2M 

Table 4.11

ADOPIM,

Flexible autonation refers to any of the manufacturing technologies listed below. Does your plant have any of these technologies? (Please circle one number for each technology.)

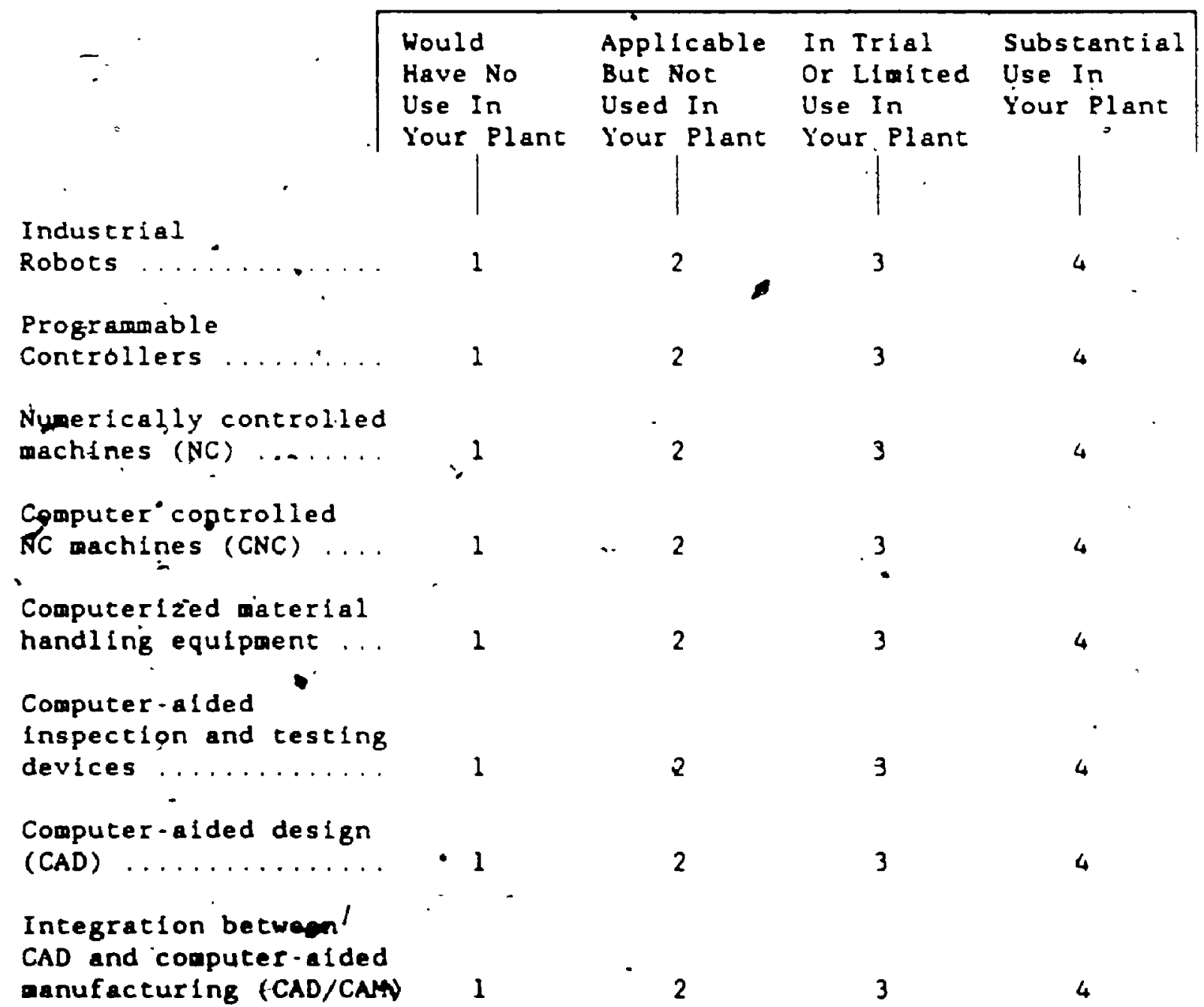

The ma:l questionnatre also included a fur liced meseure, ADOP2H, which aske respondents to compare thelr plants' adoption of flexible 
autonation with that of coapetitors. ADOP2M is the mean of each plant manager's score on the same four automation ttems that were used in the survey of GC personnel and shiown in Table 3.2 .6

I.G.Other Variables

A number of other fiteas were included in the mail questionnaire. These Items are presented in Table 4.12, and discussed in the context in which they are epplied in Chapters Five and Six.

which they are applied in chapcers Five and six.

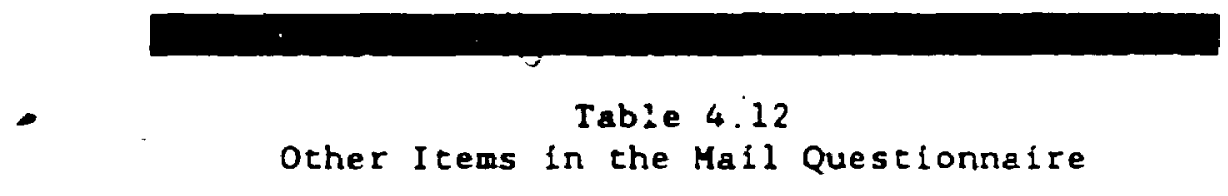

At the present time, how many people are employed full-time at your plant? people

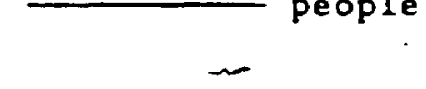

About what percent of your plant's total sales last year were made to General. Motors? $\longrightarrow$.

How many years have you been whth your company? years

How many years have you been in your current position? _ years

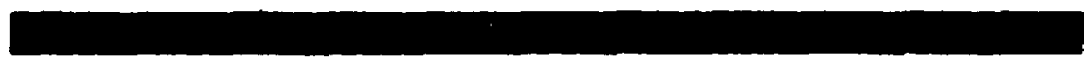

6 There is one difference between $A D O P 2 G$ and $A D O P 2 M$. As shown in "Table 3.2, the anchors of the ADOP2G acale are "Worst" and "Best." These teras ay be approprlate for external raters, but to evold comunfcating a pro-technology blas to plant sanagers, the ADOP2M anchors were "Lowest" and "HIghest." 
Section UL: Face-to-Face Interviews and Planc Vistes

\author{
II. A.Collecting and Coding the Intcrulew Data
}

The protocol used in the personal interviews is presented in Appendix D. All but two of the 29 interviews were tape-recorded. One of the intervieus was not recorded because of high nolse leveis in the manager's office and another was not recorded because the manager appeared to be very tense about being interviewed, After all the interviews were completed. I reviewed and coded the information from the plant visits Ling the coding sheet shown in Appendix $E$ The reliablity of the coding process was enhanced by two factors. First. the coding process incorporated three sources of information notes taken during the interviews, tape-recordings of the Intervlews, and

Information gleaned from the plant tours Interview notes were checked against interview recordings, and, where possible, notes and recordings were checked against observations from the plant tours : Second, the coding process was conducted in a consistent and methodical - fashion during a one week perlod after all data had been collected

\title{
II.B.Face-to-face Interview Varlables
}

A number of Interview and plant vislt variables figure in the deliberations of Chapters five and six, but, In chls chapter, I 111 only describe those varlables whlch appes in Table 4,1 and which are used in aain tests of the Model $A$ and $B$ hypotheses 
EMFEVLIF is the interifew version of the Hopwood measure of "supervisor evaluation style." Plant managers were given cards, on which were printed the 11 criteria of EMrylM, and asked to rank the criteria in terms of fmportance in their evaluations. Managers often had to be pushed to priorlze the criteria. In some cases, managers had to be asked difectly if accounting measures were used to evaluate performance, and if so, which criterion. "meeting the buiget" or "iowering costs," was most important.

TMHOR3F is the interview version of TMHOR3M, which asked managers to. report on the payback period used to assess potential investments in flexible automation, and EMFJST2F is a measure of the fmportance of payback in justifying proposals to purchase new equipment. Respondent replies to the question, "How important is payback in getting approval to buy new equipment?" were coded 0 (not important), 1 (somewhat fmportant) and 2 (very lmportant).

ADOP3F is a count of each plant's flexible automation technologies. A plant with $3^{6}$ robots, 1 CNC machlne and 2 computerlzed testing aachlnes would score 6 on ADOP3F. Because, all things being equal, larger plants could be expected to have higher scores on ADOP3F, another variable was created by adfusting ADOP3F for plant size. ADOP4FY is a ratio calculated by dividing a plant's ADOP3F acore by the number of plant workers as reported in the all questionnafre.. A plant with an ADOP3F score of 6 and $100^{\circ}$ workers would reglster .06 on ADOP4FM. 
One final measture of adoption, ADOPSF, is a single, 5 point ltem anchored by "Loi Flexible Automacion Adoption" and "High Flexible Automation Adoption." ADOPSF represents my rating of the flexible automation levels of the 24 production factlities that I personally inspected.

\section{Section III: Chapter Summary}

This chapter described the mail questionnaire and face-to-face interview instruments that were used to measure the varlables that test Models $A$ and $B$. The operationalization of the constructs in Models $A$ and B was guided by two principles: where possible, I used established is instruments, and where possible, I employed multiple measures and multiple methods of measurement. Because it is a critclcal variable in seudies of this type, I paid spectal attention to developing measures of adoption of flexible automation. Having presented the hiscory and form of the wail and interview variables. I will now analyze the results of the study. 


\section{CHAPTER FIVE}

Thls chapter presents the results of the statistical tests of the hypocheses. The chapeer is organized into six sections sectoon I explains the decision to use non-parametric statistical tests. Section I examines some descriptive statistics of the particlpating plants and managers that demonstrate the sample is appropriate and unbiased.

Section III discusses meaturement issues and Sections IV and $V$ present the actual tests of the Model $A$ and $B$ hypotheses. Section VI sumarizes the chapter.

\section{Section'L: Scatistical Methods}

Most of the measurements used in this study meet the winimum requirement for parametric tests of signiflcance (Kerlinger 1973). However, some of the inessures are only ordinal and, with missing data, the number of cases in some analyses dips below 30. Therefore, to be consistent and conservative, I tested the hypotheses with nonparametric statistics. I would note that tests of all major hypotheses with parametric alcernatives lead to exactly the same conclustons.

Unless otherwise stated, all statistical tests use the Speard correlation coefficlent. Thls non-parametric statlstic is about $91 \mathrm{x}$ a efficlent as the Pearson correlation. That is, if a correlation between two varlables does exfst in apulation, the spearman 
staclstic will have the sane level of signiflcance in a sample of 30 as the Pearson statistic has in a saple of 27 (Siegel 1956). 1

$-$ $\therefore$

When presenting correlation coefficients, I will slso report the number of cases in each analysis ( $n$ ) and the slgn!ficance levels ( $p$ ) Numbers of cases differ from analysis to analysis because cases with oissing values are eliminated on a pairwise basis That is, cases are omitted only in those analyses in which data is aissing were nontesponse was a potential problem. I checked for patterns of nonrespoinse and found no evidence of nonrandomness. Key correlations were recalculated ustng listwise deletion and chese cotrelations were consistent with the casewise deletion results

1

In keeping wifb the argument that this thesis explores a much discussed but little studied area. I use two-talded statsitcal tests Even in tests of the main hypotheses, where the literature clearly predicts the expected sign of relationships. I malntained a conscrvative two-talled approach

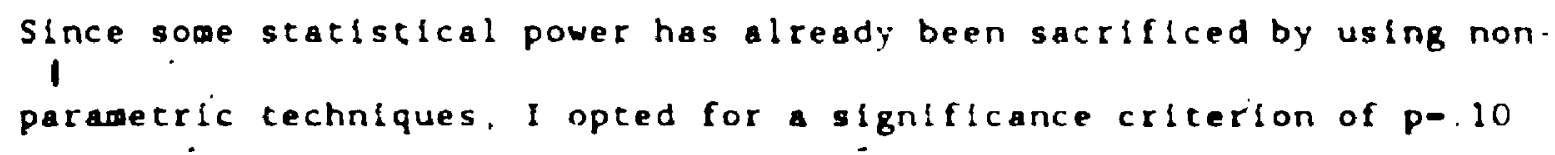

1 Data analyses were perforaed with SPSSX (Version 22 ), on the Queen's University IBM VM/CMS Dalnframe 
and sample sizes of about 30 , correlations would have to be-greacer. than 30 to be fudged significant. Cohen (1977) suggests that correlations of 30 indicate medium effect size;

To sum up. given a sample size of ebout 30 . the siatistical tests used In this study are powerful enough to refect the hypotheses if any of the Macs variables have at least a "gediun-sized" corrolation with adoption. To put it in another way, the tests are powerful enough to reject a hypothesis if the Macs variables associated with that hypothesis explain at least $100^{\circ}$ of the variance in the level of adoption. The 1iterature reviewed in Chapter Two assumes that MaCs play a major role in adoption. It shquid not be too much p expect. that if MaCS are an issue in adoption of flexible automation, the MaCS variables should explain at least $10 \%$ of the variance in adoption.

Sectien It: Sameline Issues

I have already addresfed one of the most important sampling issues: self-selection of particlpants. As shown in Chapter Three. there was Do signiflcant difference between particlpants and non-participants in cerws of the GMC personnel survey scores on automation and success.

In this section. I will examine number of other plant and managertal characteristics that relate to the approprlateness of the saple. I will frane these sopling lssues in a series of questions, first about the plants and then about the managers. 


\section{A Plant Sampling Issues}

To what extent ire the plants in the sample auppliers to General 3

Kotorat One of the reasons for studying a sample of GMC part suppliers was to control for environmental "noibe" GM was expected to be a major customer of plants in the sample But if sample plants are coo dependent on GM business. the external valldity of the study would be reduced Therefore, a "good" sample would be one with plants that depend on GM for some. but not all of their sales?

Of the 32 plants in the study, all have some dealings, with GM Sales GM range from 3\% to $95 \%$ of plant sales Only 7 plants depend on Gy for less than $30 z$ of sales and only 5 for more than $70 z$ The wean percent of sales to GM is 457 and the median 472 These results Indicate that whlle the sample plants represent GM suppllers, the a iso represent suppliers of other assemblers furcherport. the sample plants are typical of most Canadian parts suppliers in that they hayr more than one aajor customer

Are the plefits typlcel adopters of flexible autanetiont I chate to stiudy adoption of flextble automation in thls sample becouse, as ovi o in Chapter Three, there 1 s sode evidence of adoption of flexible

2 Some plents shipped parts to both GMC and American asipbly

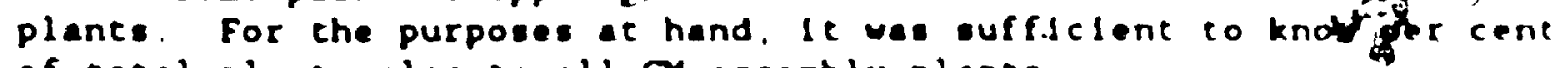
of total plant sales to all Gr assebbly plants 
autonation in the autonotive industry in general, and in these plarks in particular. As a further check on pacterns of adoption in the sample plants. I conpared sone sample and industry statistics.

Table 5.1 is simllar to Table 3.1 , except that a, third columi has been added for the resules of this study. ${ }^{3}$ Table 5.1 shows that sample adoption rates are higher than industry rates for robots, programmable controllers, computer-alded inspection and testing devices, and CAD Computerized material handing equipment adoption rates are comparable across the three studies. while CNC rates are lower in the sample. None of the plants in the study had a working CAD/CAM systew, although 7 of the plants had CAM systems with potential for CAD incerface. 


\section{Table 5.1}

Flexible Automation Adoption Rates

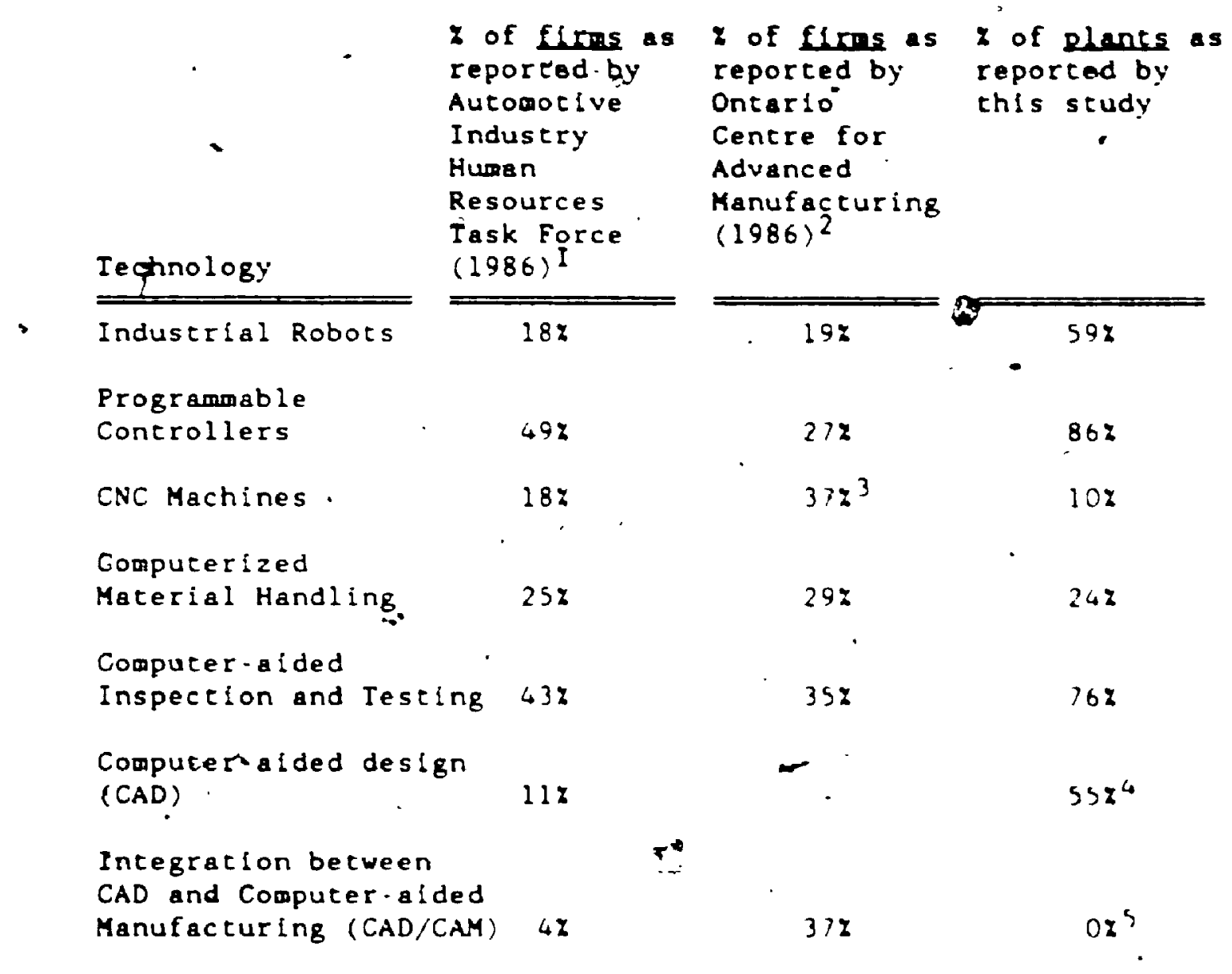

Notes:

1. Percentages taken from raw results supplied by the Autosot lve Parts Manufacturers Association of Canada

2. Reported results are for SIC 37 whlch Includes anufacturers of automoblles, boats and alrplanes

3. Combines figures for NC and CNC equipaent.

4. Includes off-ste Installations accesslble to plent

5. Seven of 29 or 242 of the plants had CAM yeteas with potential for CAD Incerface. 
The lower CNC adoption rates in this study can be explained by the fact that CNC technology is usually applfed in th achining of aetal, and few of the plants in the study achined aetal

otheldifferences between Industry and sample rates of adoption can be explained by looking at when sample plants first purchased flexible automation technologies. The two industry surveys referred to in Iable 5.1 were conducted several years ago. Forty-seven percent of the robot adopters in this study had purchased their first robots within the past year and $59 x$ within the past two years. And $62 x$ of the plants with programablé controllers had adopted this technology less than two years ago. Many of the computerized inspection and testing machine's and CAD systems were also new. Recent purchases of advancad cechnologies explain why some of the adoption rates reported here are higher than rates reported in previous teudies.

To ansyer the question at hand, Le poods there are no major. unexpleined differences between the patterns of adoption of flexible automation In the study's sample plants and in the'Industry in'general.

\section{B. Respondent Characteristics}

$\rightarrow$

Are the eurpeg respandents plant anagers? All 29 managers who were personally intervlewed wet the formal definftion of plant aanager: they were responstble for the operation of thelr plants and they could Inltlete but not approve capltal budgeting proposals. Nevertheless 
respondents vere clearly not all allke. Some vere responsible for both. manufacturing and sales, others only for manufacturing. Soae vere part owners of their firas and had a drect say in capleal expendicures. others only inltiated proposals. Sone reported directly to top managenent. others. 'were four or five levels below top aanageaent. I captured these differences in two managerial position varlables: MANPOSIF (hletarchical levol) and MANPOS2F (cost/ptogit centre). Sumary statistjcs of MANPOSIF and MANPOS2F are displayed in Table 5.2 .4 While the respondents were, by definition, plant managers. there is sufficient varfation in the two hierarchical varlables to warrant controlling for MANPOSIF and MANPOS2F in the tests of the Model B hypotheses, and as will be argued shortly, also in the tests of the Model A hypotheses. 


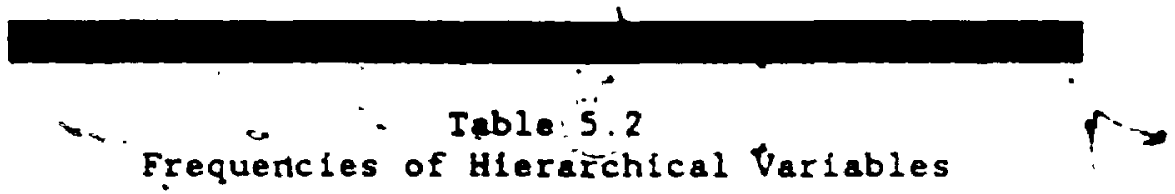

MANPOSIF

1 - lower-level manager

2 - Id-level manager

3 - upper-level manager
5 respondents

9 respondents

15 respondents

MANPOS $2 F$

1 - no sales responstbility

2 - some responstbility for sales

3 - responsibility for sales

18 respondents

2 respondents

8 respondents

?

- Hov long heve respondents and thelr supervisors held thelr current "posifions? Job tenure could affect the fesults of this scurdy: in two. ways: a respondent only recently appointed to his position aight give

- less accurate reports of the varlables of Interest, and recent changes in the rejpondent/superviso5 dy ad could wean changes in how MACs are - used (Hopwood 1973). My conctusions are valld only in so far as the measured characterlstics and uses of maCS are those assoclated with the adoption of flexble automation. If there had been changes to a MaCs after the adoption of flexible autonation, it would be nisiading to assoclite the new characteristics and uses with the adoption.

The wall questlonnalre responses showed that on average, the 32 anagers in the scudy had been with thelr flras, 9.5 gears and in their current positions, 3.6 years. However, 5 of the respondent had been with their current company one year or less and 8 reapondents were in 
their current posftion one year or less. There was an obvious need to check the accuracy of responses to key questions and to ensure that adoption measures were matched with the appropriate Macs varlables. Verification was accomplished in the face-to-face incerviews.

The Interview process revealed that respondents had no problem in providing the information required for the study. The interviews also confirmed that desple changes in personnel, the characterlstics and uses of MaCs remained stable óver time. That MaCs are stable is not surprising when one considers the forces that work to keep a Macs from changing: functical fixation (Ifirl 1967), the preservation of power (Markus \& Pfeffer 1983), and contagion effects (Hopwood 1973). In. several cases, even changes in firm ownership had not changed the - MaCs. 5 And, in the few instances where long-time plant managers reported some changes to the MACS. I ascertained that the changes in the MaCS had preceded the adoption of flexible automation. I would therefore conclude that job tenure of plant anagers was not a factor in this study.
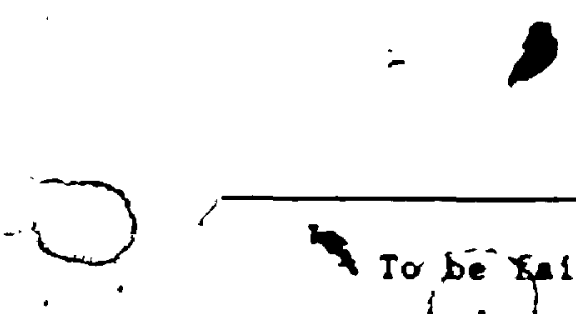

To bé talr. changes in plant ounershlp were all very recent 
Section IIL: Measurenent Issues

III.A.Measures of MACS and Decentralization

III.1.R.R11ab111ty

Table 5.3 summarizes the reliab:11ty checks performed on the measures

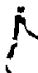
f MACS and decentralization. After discussing the reliability tests, I will look at the measures' construct validity (convergent and discriminant validity).

As shown in Iable 5.3, pll mult-1tem measures have Cronbach's alphas greater than the minimum standard of .50 , but three measures have alphas below $.70 .^{6}$ I will discuss the low reliabilities of these three measures: TMHORIM, TMHOR2M and EMFJSTIM.

TMHORIM and TMHOR2M are formative rather than reflective measures (Fornell 1984). That 1s. I do not posit an underlying latent variable that "causes" THHORIM and TMHOR2M. Each of these two constructs is defined as a sum of three possibly independent items. For example, TMHORIM is the sum of scores on the following ltems: the period of tine covered by the most frequent budget reports, the time horlzon of

6 The lower lialt of acceptabllity for Cronbach's alpha is .50 (Merchant 1981, Nunally 1967). However. Nunally (1978) suggests a more etringent criterion of .70 For measures used in the "early stages of research." 
the most imediate budget targets, and the shortest time span of the formal evaluations. Loglcally, scores on these three fteas need not be correlated and low inter-ftem correlations result in low rellabllity coefficlents. Since there is no reaspn for the lteos in Myprim and MMOR2M to be correlated among themselves, the low reliabllity of these two measures does not imply low validity. However the low reliability scores do Inflate a need to test not only the relationship between the two variables and $A D O P$, but between the individual 15ems in the two measures and ADOP

The third measure with low rellablifty is EMFJSTIM The rellabllity of this scale can be ralsed to .63 by dropping the tem when it comes to new technology, the only thing top management wants to know is 'How much wili it cost?'.... However. the improvement in Cronbach's alpha is marginal and the item has face validity, so lt is retained in the scale. 

Before proceeding further. I would coment on the appropriaceness of calculating Cronbach's alphas with small samples. Nunally (967)

suggests internal reliability tests should have 5 ta 10 times as many cases as ltems pet measure. Reliabllity estimates may be overestimated for those measures that do not meet this requirement (Peter 1979). However, a comparison of the Cronbach's alphas in Table 53 with those reported by other researchers shows that over-estimation of reliability is not a problem in this study. Merchant (1981) reports a reliability of 84 for EMFEVL2M and reliabilities of 79 and 74 for the two subscales of EMFEVL3M Dewar. et al (1980) 'report Cronbach's alphas ranging from .70 to .96 in several applications of DECENT2M. However, the reliabillty estimate of .96 comes from a sample size of only 16 and may overestimate true rellability The reliabllity estimate of .70 , from a sample of 72 . Is more accurate and is consistent with the alpha of DECENT2M in this "study.

Moving on to the alternate form/test-retest rellabillties, the low correlation between replications of EMFEVLl casts doubt on the reliablifty (and hence validity) of chese Instruments The low correlation of. 39 between EifEVLIM and EMFEVLIF, can be partially explained by the tolue span between replications, whlch in wost cases was about 2 mopths. And of course the two measures were adoinlstered by different pethods: EMFEVLIM by wall questionnalre and EMFEVLIF by personal interview. As well, the results of the dall questonnalre were highly sensitive to the coding scheme. For example. two of the managers ranked "cost" as the fourth most impreant criterion in how 
they vere evaluated. They were classffled in the Profit oriented category df mafevil.. However, the perscral interviews clearly showed then as belonging to the Nonaccounting category. A different coding schene for EMFEVLIM, which considered only the top three criteria, would have correctly identifled the role of Macs in the evaluation of these tu $\{$ managers. 7 .

Although low correlations between EMFEVLIM and EMFEVLIF way mean that either or both of the instruments are invalid, there is evidence of two fundamental problems with the mail version. First, 6 of the 32 or $19:$ of the respondents did not properly complete EMFEVIM. 8 They assigned numbers from 1 to 4 to all 10 criteria. That is they listedopeveral criteria as being most important in their evaluation, several criteris" as being second most important, and so on. These multiple responses could not be coded. A few of the loproper responses may have been caused by alsunderstanding of the instructions, but in the face-toface interviews it was found that many managers are evaluated on multiple. equally important, criteria and judging from their reactions, these managers could not easily priorize evaluation criterla.

A second fundamental problem with EMFEvilM is that its validity depends on the assumption that respondents Interpret words like "cost" ard

7 As Indlcated In Chapter Four, I used Hopwood's coding scheme but, a suggested by Brownell HIrst (1986). consldered the four highest ranking crlterla.

8 In Brownell (1982), is of 48 or $17 x$ of the respondents Improperly completed the Hopwood evaluative tyle seasure (EMFEVLIM). 
-budget" the same way. EMFEVLIM was originally designed to survey manufacturing managérs within a single large coapany and so Hopwood (1973) and otley (1078) tailored the instrument for the coapany in which it was applied. For example, Otley translated Hopwood's "concern for cost" to "concern for efficiency." Other researchers have ased JMFEVLIM in mail questionnaire studies of managers of manufacturing and nip-manufacturing departments of the same firm and managers of business units in several different firms (Brownell and Hirst 1986. Govindarajan 1987). Results of this study would suggest that te may be inapprcpriate to use the mail questionnaire version of EMFEVLl to survey managers il different firms From the interview sessions it became obvious that managers had different interpretations : evaluation criteria. For example, some managers interpreced "budgets" to mean cost objectives while others defined budgets as detaljed pbans for achieving targets for sales, costs, return on investment, worker satety, and custcmer satisfaction Differences in interpretation of EMFEVLl criteria could only be reconclled through persongl interviews: I therefore decided to use EMFEVLlF as the definitive opasure of evaluative sityle and dropped EMFEVLIM from the study o . Referiffg to Table 5.3 again, and the last of the relpability cests. there is a high correlation $(.63,6-.007$ between THMOR $3 M$ and TMHOR $3 F$. the mafl questionnalie and personal interview measures of payback in the literviews, anagers often differentated between formal fir paybaok arlterla and personal. rule of thumb, payback. For extaple. one manager who had reported a 24 -month paybeck crlterton on JuHOR3M i 
adnitted to using a 12 -sonth payback to evaluse projects because he want d to ake sure he had "vinners." then intervlewed, nanagers differentiated between personal and fira payback criterla, I coded

TMHOR3F with the personal cititeria. Thus, TMHOR3M could be interpreted as ine formal. firw payback criterta and TMHORz personal payback. criceria since TMHOR3M and TMHOR3F are highly - corrglated, and since there is not wuch difference in the mears of the ewo beasures I recained only one of the aeasures. 9 I chose TMHOR3F because it represents the actual payback criterion used by the plant manager The MMHOR3M response was used in cases where TMHORzF was wissing.

To recap this discussion of reliability, all multipleitem measures met minimun standards for internal reliability. However, analysis of the low alcernatg form reliability of EMFEVLl indicated problems with the instrument and led to the abandonment of the mail questionnalre version, EMFEVLIM $\because$

III.A.2. Construct Validiey

KIdder (1981) says that construct valldlty requlres agreement on scores obtained with instruments measuring the sade construct (convergent validity) and some differales on scores obtalned with instruments measuring different constructs (dlscrlminant validity). Though there

9 The mean TMHOR3M payback is 28 morths and the mean TMHOR3F payback, 27.4 months. 


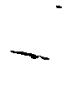

are no set criterla for establishing construct validfty. correlarions among aeasures of the sane construct sholid be larger than correlations anong mesures of different constructs. A look at Table 5.4 shows chat the pattern of correlations anong the Macs and decentralization variables generally supports construct validity but that there are only small differences between convergent and discriminănt correlations For gxample: While the correlations mone the EMFEVL and EMFJST variables are generally higher than the correlations between. EmFEVL and EMFJST variables, "the average correlation among measures of EMFEVL is only 38 and the average correlation between EMFEVL and EMFJST weasures 15.23 .

One of the conclusions that may be drawn from Table 54 is that each of the measures used in this study represents.related but separate constructs: Thus, even trough I use the shorthand emfevl for "emphasis on MACS In evaluating manegers". I am actually referring to three consteucts: performance evaluation style (EMFEVlfi), emphasts on budget variances (EMFEVL2M), and intrinsic and. extrinsic motivation of budgets (EMFEVL3M). In other words. I an defining "emphasis on MaCS in a evaluating aanagers" In teras of EMFEVLIF, EMFEVL2M and EMFEVL3M. similar Interpretations may be made of the TMHOR. EMFJST and DECENT vartables. 10

10 This 1: comon practice. For example. Merchant (1981) labels the three aultilited varlables. "requlred explanetlons of varlances." "reactions to expected budget overruns" and ilink vith corporate revard systed," as measures of IDportance of meeting budfets." 

Tal 54

Coovertwe cot Diecriesnent Palidily

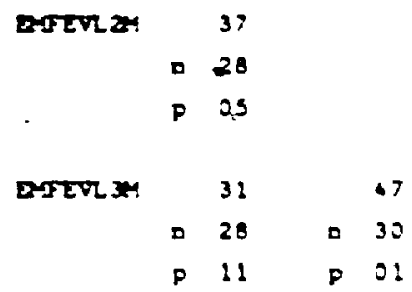




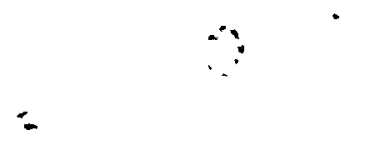

III.B.Measures of Adoption

\begin{abstract}
.
Six instruments were used to measure adoption: an elght iten scale from the aafl questionnalte (ADOPIM), four ited assessuent by each aanager of his plant's level of autonation (ADOP2M), a four item assessment by GMC personnel of each plant's level of autonation (ADOP2G), a count of flexible sutomation installations frow the face-to-face interviews (ADOP3F), a ratio created by dividing ADOP3F by the number of plant workers (ADOP4FM), and wy rating of the adoption levels of the 24 plants I toured (ADOPSF).
\end{abstract}

$A D O P 2 M$ and $A D O P 2 G$ have Cronbech's alphas of .89 and .93 . The other multiple ltem instruments are slmply equipment counts and require no tests of internal reliablitity.

6 Table 5.5 shows that five of the six measures are significantly correlated among themselves. 11 The one exception is ADOP2G. There are two reasons why ADOP2G, the GMC rating of adoption, is not signiflcantly correlated with the other variables. First, the GMC survey was conducted several months before the survey of plant aanagers. As noted earlier, any of the flexible autonation - tachnologles counted in thls atudy had bean Iaplenented very recently and may not have been known to the GMC raters. As well, GMC raters may

11 since the direction of the relationships anong the ADOP varlables can be expected to be postelve, Table 5.5 shows one-talled frobablilties. A Ignificant corralation is one with a probability. lower than .05. 
have orily incidental knowledge pout supplier technologies. Things like quality. on-time defivery. and price would be of nore lanedlate concern to raters.

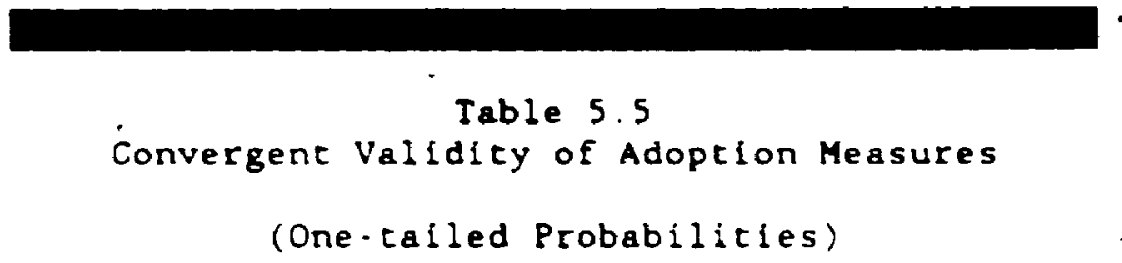

ADOP $2 M$

.47
n
p .01

ADOP $2 G$

$\begin{array}{rrrr} & 27 & & .19 \\ n & 28 & & 31 \\ p & 37 & & .15\end{array}$

ADOP $3 F$

\begin{tabular}{rr}
.63 \\
$\pi \quad 26$ \\
\hline
\end{tabular}

$78^{\circ}$

ก 29

P. .00

$\quad .17$
n 28
p .20

ADOP4FY

.57
n 26
$p \quad .00$

.56

ก 29

n $: 27$

p. 00

p. .08

ADOPSF

67

.67

ก 21

p. 00

ก 24

p. .00

$\begin{array}{rr} & 24 \\ \text { n } & 23 \\ \mathrm{p} & .14\end{array}$

3

ADOPIM

ADOP2M

ADOP2G
. 66
ก 29
p. .00 .

\begin{tabular}{|c|c|c|c|}
\hline ADOPIM & $A D O P 2 M$ & $\triangle D O P 2 C$ & ADOP $3 F$ \\
\hline
\end{tabular}

I considered combining the flue correlated measures of adoption into one scale, which would have ' Cronbach' alpha of .82 , but chls epproach would have several shortcosings. Only 21 plante thad a complote set of scores on the 5 mesures. Another iliernitive. analyzing 5 separate adoption deasures, vould be coo unuleldy. 

I chose to use ADOP2M, respondents'self-ratings, as the second nedsure of adopelon because it provides a.dfferent method triangulation on ADOP4RM. Furthermore, while there are ADOP2t scores for all 32 plants, ADOP3F has three wissing values. Finally, because ADOP2M is highly correlated with ADOP3F $(: 78)$. ADOP3F may be dropped with little loss of unique variance.

Suming up, after going through the process described above. I chose to use ADOP2M and ADOP4FM as measures of adoption. Together: these two very differenceasures, five a beter representation of the construct. "adoption of flexible automation." than would any single measure.

\section{ILI.C. Sumary statistics:}

Table 5.6 presents sumary statistics of the main varlables in Models A ara B. Along with the magn, possible range, actual range and standard deviation, the table also shows a theoretical mean for Likert-scale Instruments with neutral aidpolnts. For example, each of the $1 \times 1$ iteas of DIFQUNIM is acored on appolnt scale with I-strongly disagree and "5-strongly agree. The aidpoint, 3, 1s-tabeled -neutral." DIPQUNin's thooretical wean of $18 \mathrm{ls}$ thus a rough gulde di to whether respondents agkee or disegree with the proposition that it la difficult to quantify costs and bentefits of flexible cutometion. Since the sean score on, DIFQUN1M te 16.5, it can fat ald that, In general, respondents disegree with statesents that it is difflcult to quantify the benefles and costs 
of flexible autonation. This may explain why so few of the aanagers I intervlewed volunteered criticlsas of the role of MaCs in justifying advanced technologies. 12

Inbles.s

Sumery Stetlalter of Partebles in Models A ad B

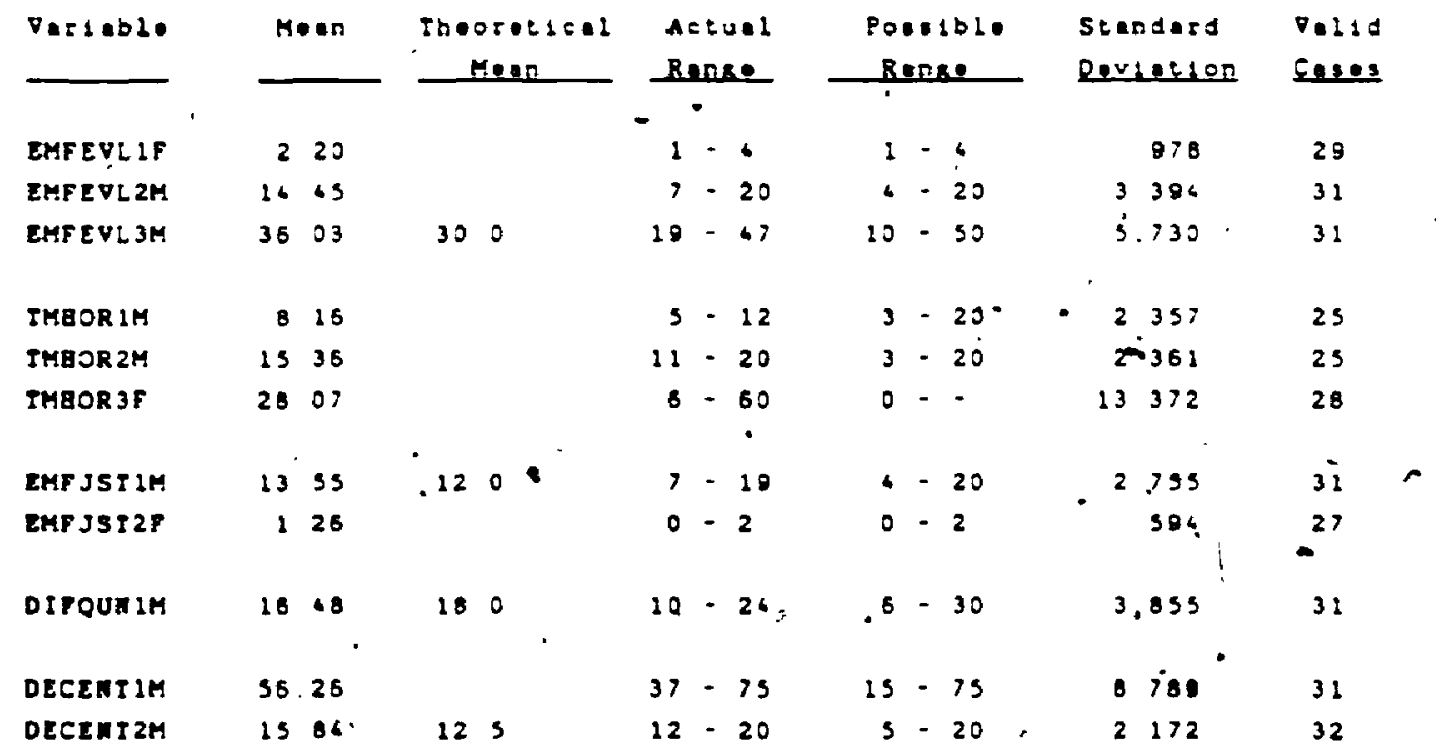

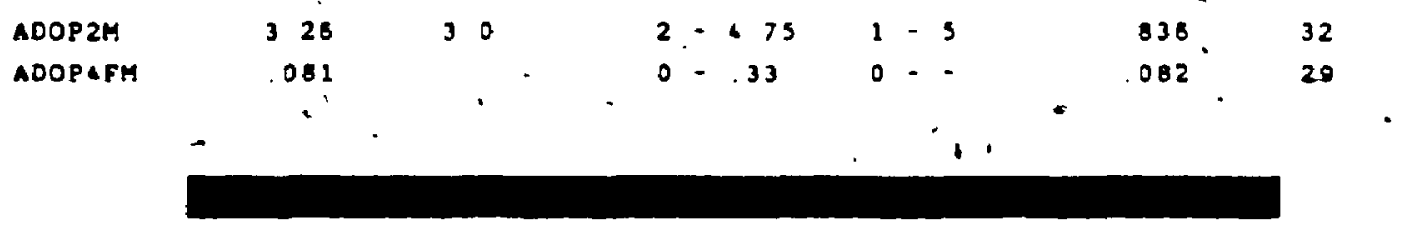

Here are Interpretations of other comparisons between actual and. theoretcal means:

12 Fully $77 \%$ of the mall questionnal re reppondents had meri. acores of 18 (neutral) or lower (disagree) on ltems suggesting it is difficult to quantify costs and benefits of flexible autoantion. 


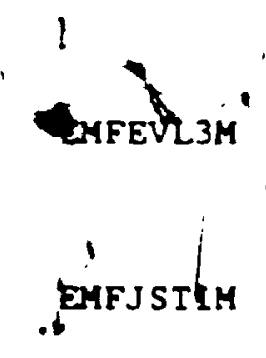

On average, respondents agreed that budget performance was intrinslcally and extrinsically gotivating.

DECENT2M On average, respondents agreed that there was decentralization of work control. 13

ADOP2M on average, respondents rated their plants as having more flextble automation than competitors

Section IV: Tests of Model A

IV.A Main Hypotheses

Table 5.7 shows the correlations between the adoption varlables and each af the MACs variables. The correlation coefficlents do not refute the rulli verstons of $H 1$. $H_{3}$ and $H 4$. The MACS variables representing those three hypotheses are not related to adoption Therefore, I must Accept the following hypotheses:

H1: $\quad$ Emphasis on accounting measures in evaluating manegers is not related to the, adoption of Texible automation.

H3: $\quad$ Emphasis on flnanclal criteria in Justifyling investaent in flexible automation is not related to the adoption iof such technologies.

13 The re was no labelled aldpolne in the DECENT2H iceas Respondents were forced to agree or disagree wlth each tatement However. there 1s an Iaplied aldpolnt of 12.5 . Since DECENT2M responses were reverse coded. a rcore greicer than 125 would indlcate a respondent felt he had control of hls own job, 
H4: Difficulty in quantifying the costs and benefits of flexible automation is not related to the adoption of such technologies.

The correlations between TMHOR and ADOP partially refute $H 2$. While the MACS short-term time horizon (MMORIM) and the length of payback criteria (TMHOR3F) are not significantly correlated with adoption. these twa variables do have consistent, positive relationships with adoption. However, TMHOR2M is significantly correlated with both measures of adoption. This suggests that firms with longer time horizons for budget reports. performance evaluations and budget targets do have more flexible automation. To restate $\mathrm{H} 2$ :

The time horizon of accounting measures may be related to the adoption of flexible automation.

$\Delta$

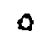


Table 5.7

Tests of Model A Hypotheses

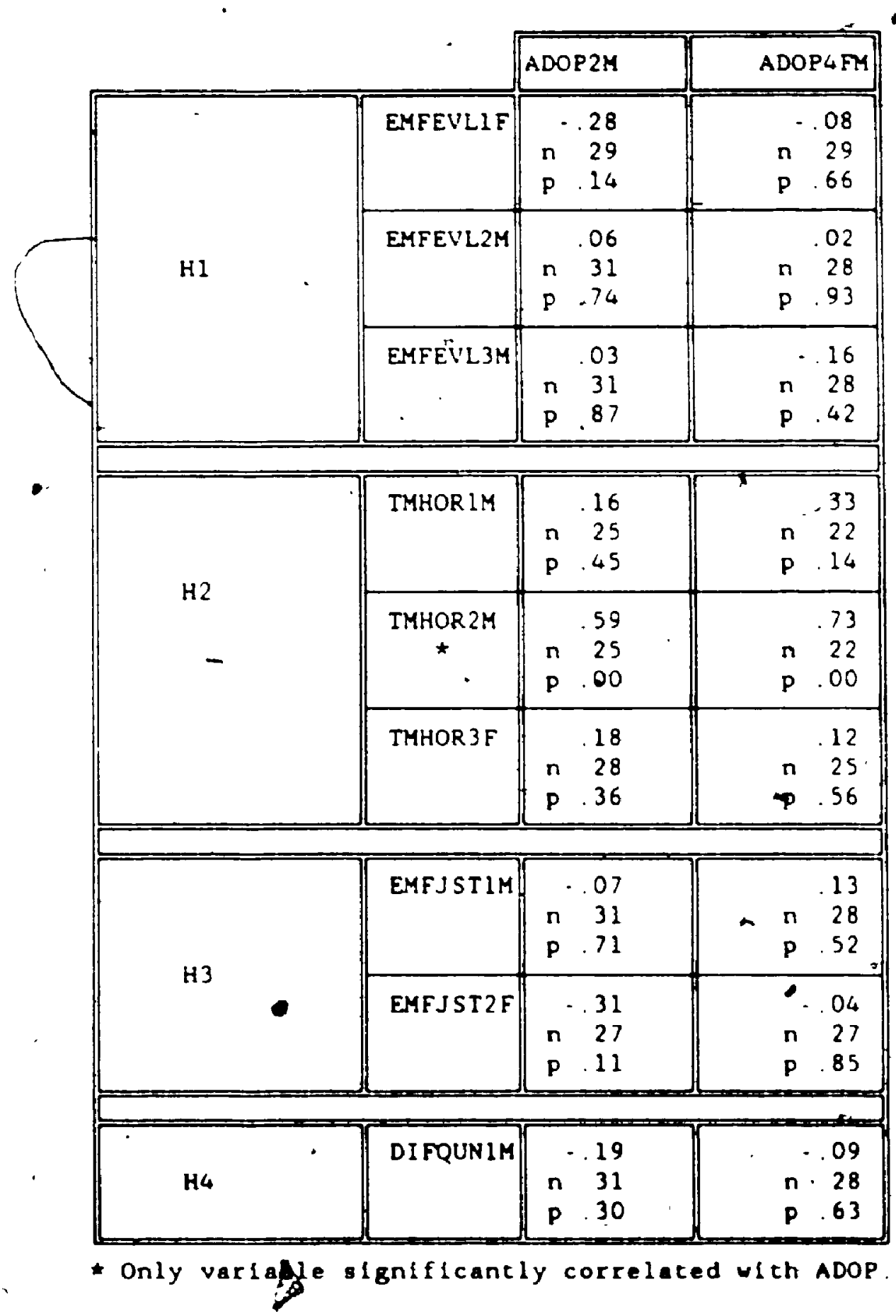

$\dot{r}$. 
- To better understand the $H 2$ results. I wlll look at the correlations between adoption and the six individual items in MHORIM and MAHOR2M. Table 5.8 lists the one-talled probabilities of the time horfzon varlables with ADOP2M and ADOP4FM. 14 This table makes three points First it shows that:

The longer the longest time period for which budget targets are set, the greater the adoption of flexible automation.

The longer the longest time span of budget reports, the greater the adoption of flexible, automation

The longer the fongest period of time for which format-evaluations are conducted, the greater the adoption of flexible automation.

Second. Table 5.8 shows that the correlation betwe in the LONGEST FORMAL EVALUATIONS variable and ADOP2M is not significant at the .05 level. though the correlation between LONGEST FORMAL EVALUATIONS and ADNP4FM is ifignificant. Both of the LONGEST FORMAL EVALUATIONS correlations must be interpreted with caution because of reduced sample size; -6 of: the 32 respondents reported no formal evaluations. 15

14 Having established the direction of the relationships, one talled tesis are appropriate. To malntain the same power as for the two-talled tests, the agnificance criterion has been set at p-.05.

15 I checked if there were differences in adoption levels between those plants whose managers are formally evaluated and those plants whose managers are not. Non-parametrlc Mann-thiteney $U$ rests show no differences between the two groups on ADOP2M and ADOP4FM (P-.44 and p-.42). 
Table 5.8

Correlations Betwaen Ilme fiorizon Items and Avioption (One-tailed Probabilities)

\begin{tabular}{|c|c|c|c|c|c|}
\hline . & & & ADOR2S & $A D O$ & $4 \mathrm{FM}$ \\
\hline \multirow[b]{2}{*}{ • } & \multirow{3}{*}{ TMHOR IM } & $\begin{array}{l}\text { TIME PERIOD OF } \\
\text { SHORIEST BUDGET } \\
\text { TARGETS }\end{array}$ & $\begin{array}{r}.08 \\
n \quad 30 \\
\mathrm{p} \\
34\end{array}$ & $\begin{array}{l}n \\
p\end{array}$ & $\begin{array}{l}22 \\
27 \\
13\end{array}$ \\
\hline & & $\begin{array}{l}\text { TIME PERIOD OF } \\
\text { SHORIEST BUDGET } \\
\text { REPORTS }\end{array}$ & $\begin{array}{r}00 \\
n \quad 30 \\
p \quad .50\end{array}$ & $\begin{array}{l}n \\
p\end{array}$ & $\begin{array}{l}22 \\
27 \\
14\end{array}$ \\
\hline \multirow{4}{*}{ • } & & $\begin{array}{l}\text { TIME PERIOD OF } \\
\text { SHORTEST EORMAL } \\
\text { EVALUATIONS }\end{array}$ & $\begin{array}{l}29 \\
n \quad 26 \\
p \quad .07\end{array}$ & $\begin{array}{l}n \\
p\end{array}$ & $\begin{array}{l}28 \\
23 \\
10\end{array}$ \\
\hline & \multirow{3}{*}{ TMHOR2M } & $\begin{array}{l}\text { TIME PERIOD OF } \\
\text { LOAGEST BUDGET } \\
\text { TARGETS }\end{array}$ & $\begin{array}{ll} & 45 \star \\
\text { n } & 30 \\
p & 01\end{array}$ & n & $\begin{array}{l}45 * \\
27 \\
01\end{array}$ \\
\hline & & $\begin{array}{l}\text { IIME PERIOD OF } \\
\text { LONGEST BUDGET } \\
\text { REPORTS }\end{array}$ & $\begin{array}{ll} & 53 \star \\
n & 30 \\
p & 00\end{array}$ & $\begin{array}{l}n \\
p\end{array}$ & $\begin{array}{l}60 \star \\
27 \\
00\end{array}$ \\
\hline & & $\begin{array}{l}\text { TIME PERIOD OF } \\
\text { LONGEST FORMAL } \\
\text { EVALUATIONS }\end{array}$ & $\begin{array}{r}.30 \\
\text { n } \\
\text { p } \\
.07\end{array}$ & $\begin{array}{l}n \\
p\end{array}$ & $\begin{array}{l}58 \star \\
23 \\
00\end{array}$ \\
\hline
\end{tabular}

Sign-ficant correlations with Abor.

The third porint lliustrated by Table 5.8 is that the tloe periods of the shortest targets, reports and evaluations are not correlated with the adoption variables: Automation is related to gaxipum tine perlods racher than ainlaum tine perfods of budget targets and reports for an 1dea of the effect of long term the horlzons on adoption. consider that the vaplable, LONCEST BUDGET REPORTS. by ltself, explains 258 of the varlance of ADÓP2M and 318 of the varlance of ADOPGFM 
FV. B. Respondent Rank and Hodel A

Earlier, I presented evidence that respondents were at different* hierarchical levels It is possible that the MaCs variables refleco not only the characteristics and uses of MACS but also respondent position To assess that posslbility, the Model A relationships vere retested with statistical controls for MANPOSIf and MANPOS2F

Table 5.9 compares the Model A zero-order Kendall rank correlation coefficients with first-order Kendall partial rank correlation coefficiencs. There are no large differences between zero and first order correlations. So it appears that MANPOSfF and MANPOS2F do not affect the observed correlations bejtwen Macs and adoption. 16

16 SPSS $^{x}$ was used to calculate zero-order Kendall correlations from which were calculated Kendall partial rank correlation coefficients (Slegel 1956, p. 226). Since the sanpling distribution of the Kendall partial correlation is not known, test of algniflcance are not possible. However, Siegel (1956) glves an exanple where, on the basis of anall difference between zero and first-order correlations. he concludes that the relationship between two varfables is relatively Independent of the Influence of the control variable. The discussion of partial correlations continues in Section V: Tests of Hodel $B$. 
Table 5.9

Mode! A (Controlling for MANPOS)

EHEEVLIF

EMFEVL2M

EMFEVL $3 M$

TMHOR IM

-THHOR 2H

TMHOR $3 F$

EMFJSTIM

EMFJST2F

DI FQUNIM
EMFEVLIF

EMFEVL2H

EAFEVL $3 M$

TMHOR IM

TMHOR 2M

TMHOR $3 F$

EMFJSTIM

EMFJST2F

DI FQUN $1 \mathrm{H}$

\begin{tabular}{|c|c|}
\hline $\begin{array}{l}\text { First-order } \\
\text { Kendali r } \\
\text { with ADOP2H } \\
\text { (MANPOS } \\
\text { Partialed } \\
\text { Out) }\end{array}$ & $\begin{array}{l}\text { First-order } \\
\text { - Kendall r } \\
\text { with ADOP2M } \\
\text { (MANPOS? } \\
\text { Partlaled } \\
\text { Out) }\end{array}$ \\
\hline-026 & .020 \\
\hline 005 & 005 \\
\hline 003 & 00. \\
\hline 013. & 018 \\
\hline $04 ?$ & 040 \\
\hline 015 & 010 \\
\hline .004 & .003 \\
\hline .027 & .0 . \\
\hline .013 & .015 \\
\hline
\end{tabular}

0. order

Kendall $r$

with ADOP 24

\begin{tabular}{ll}
\hline 0 & 25 \\
0 & 05 \\
0 & 03 \\
0 & 13 \\
0 & 47 \\
0 & 15 \\
.0 & 04 \\
.0 & 27 \\
.0 & 13
\end{tabular}

0 -order

Kendall r with ADOPLFM

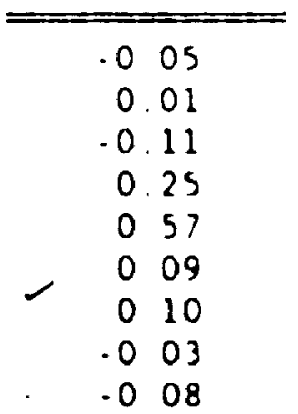

Firse-ordy

Kendall $r$ with ADOPAFA (MANPOSI

Partialed Out)

$\begin{array}{rl}.0 & 06 \\ .0 & 00 \\ .0 & 12 \\ 0 & 26 \\ 0 & 57 \\ 0 & 09 \\ 0 & 10 \\ .0 & 03 \\ .0 & 08\end{array}$

First-urder Kendall $r$ with ADOP 4 FM (MANPOS?

Patclaled Oue)

$\begin{array}{ll}0 & 01 \\ 0 & 01 \\ 0 & 12 \\ 0 & 25 \\ 0 & 51 \\ 0 & 08 \\ 0 & 10 \\ 0 & 03 \\ 0 & 08\end{array}$




\section{a \\ IV.C.Other Tests}

For the final test of this section, I used non-parametrfc Mann-Whitney $U$ cescs to see if there were any differences in the Macs variables in plants with, and plants without, Integrated installations of flexible. automation. As I mentioned in confunction.with the discussion of Table 5.1. seven of the plants in the study had installed integrated automated manufacturing systems that had the potential of interfacing with CAD systems. Rather than replacing one function with a robot or a programable controller, these firms had automated entire lines or complete manufacturing processes. I classified these firms with a dichotomous variable (CAMUSE). 17 Compared to other plants, plants with) integrated systems have made a greater comitment to flexible aucomacion. 12

Using two-talled Mann-Whitney U Tests, and setting the level of significance at p-.10. I found the two CAMUSE groups differed on only one variable: TMHOR2M. Plants with integrated flexible automation

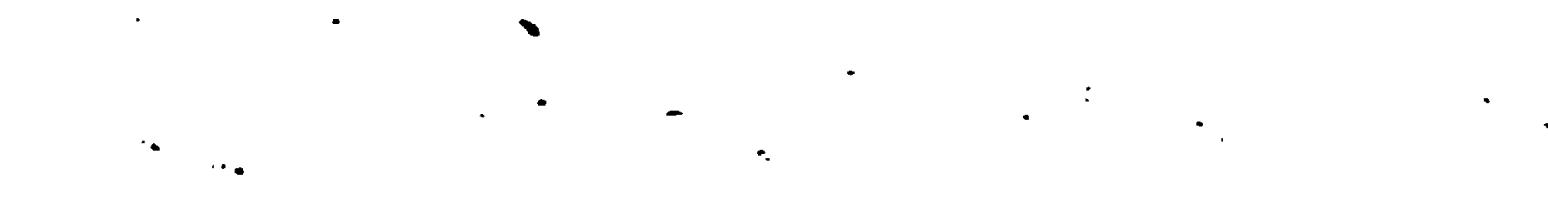

17 See Appendix E: Intervlew Coding Sheet.

18. As a rough guide, the least oxpensive iffegrated gysten in this sample cost about 10 tines as much as atand-alone robot. Integrated ystems are complex and require much bore managesent Involveaent than ctand-alone implementations. In short, investing in an integrated systens is more of a stratagic declsion than a tactical one. 
have longer time horfzons for formal evaluatlons, budget reports and

a budget cargets $(p-.07), 19$

To recap this section, the tests of the Hodel a hypotheses clearly

Indicate that TMHOR2M, and in partfcular the length of budget cargets and reports, is related to the adoption of flexible automation None of the other varlables were signiflcantly correlated with adoption.

leaving we to conclude that emphasis on accounting measures for

performance evaluation. emphasis on financial measures in

justification, and difficulties in quantifying automation beriefits are not related to the adoption of flexible-automation

Section $v$ : Tescs of Model $B$

-
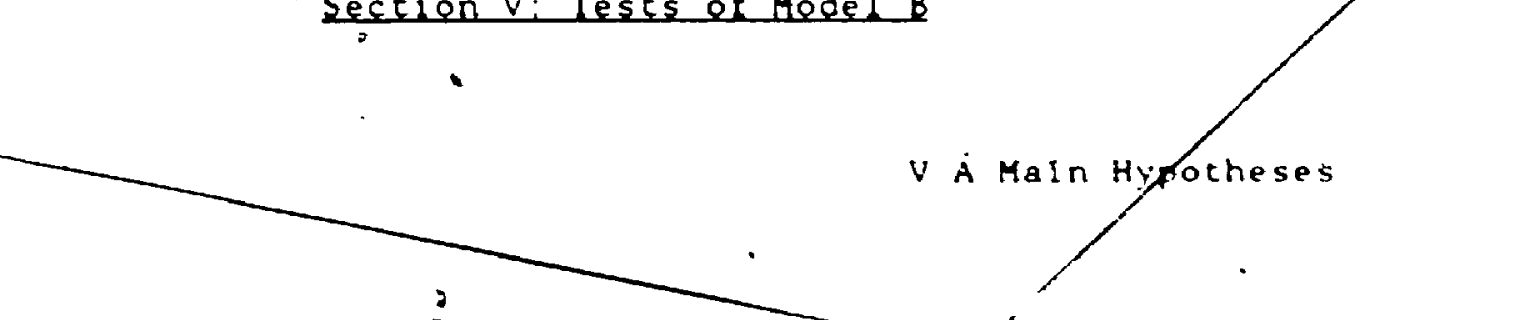

Scudics have shown decentratization to be related to characterlstics and uses of MaCS and to adoption of Innovations-As reported in

Chapter 2, decencrallzed firms ake greacer use of macs for concroiand declsion-aaking and;decentralization asy be postelve or negat ive Influence on adoption: Therefore. to deterolne the true" relationsh!p

í.

19 The strong relationship between TMHOR2M and ADOP in the , plants with intigrated flexible automation may ask the true relationahip by'tween MaMOR $2 M^{\circ}$ and $A D O P$ in the ocher fires then only plents wlthout integrated technology were consldered. che correlat lon between TMHORQH and ADOP2M drapped to.39 (p- 12) and the correlat lon between TriHok $2 \mathrm{M}$ and ADOPGM dropped to 69 (p- DO) Thle demonetratex the consletgncy of the relationshlp between edoption and MHHOR2M In both Canus groups. 
between $A D O P$ and EMFEVL and $A D O P$ and DMFJST, the effects of decentralization aust be partaled out. Here again are the two hypotheses represented by Model B:

H5: There is no relationship between exphasis on accounting measures in evaluating managers and adoption of flexible outomation after the effects of decentralization are partialed out.

H6: There is no relationship between emphasis on financial criteria in justffying investment in advánced technologies and adoption of flexible autonation, after the effects of 6 decentralization are partialed out.

Partialing out the varlance due to a variable may be thought of as holding that Variable constant. Hypotheses 5 and 6 may thus be seen as cests of the relacionship between MaCs and adoption while holding decentralidion constent.

Comparisons between: =ero and first-order correlations in Iable 5.10 show that decentralization has little impact on the relationship between MACS and adoption. For example, the zero-order correlation between EMFEVLIF and ADOP2M is -.25 . With DECENTIM partialed out, the correlation remains unchanged at -25 . WIth DECENT2M partialed out, the correlation drops to,- 22 . In typlar fashion. Table 5.10 compares the zefo-order correlation between EMFEVIF and ADOP4FM $(-.05)$ ayd the " correlations between those twö variables when DECENTIM and DECENT2M are controlled $(-.07$ and $\cdot .05)$. Because there is little difference between

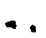
zero and flrst-order correlations anong the varlables represented by $H S$ and H6, I must ecept the two hypotheses. 

zero and ffrst order Kendall correlations between MACS and ADOP aay differ under various assumptions of the relationships between MACS and DECENT and ADOP and DéCENT. I w111 explain Table s.11 by discusing each of the columns in the table:

Colum 1 Tests of Model A have already established that, with the exception of TMHOR2M, thare are no significant correlafions between the MACS variables and ADOP.

Therefore, as suggested by the literature. I assume a negative correlation between MACS and $A D O P$ and arbitrarily choose a value) of - .20 to represent the MACS. ADOP relationship.

Column 2 Cohen (1977) defines small, medium and large correlations as $.10, .30$ and .50 but he notes that "one rarely if ever encounters (correlations of .10 ) on samples large enough to yield standard errors small enough to distiugulsh them from (correlations) of zero." For the purposes of the simulation. I define a small correlation to be 20 , a medium correlation to be .30 and a large, correlation to be .50. As suggested by the 1 iterature, MACS and DECENT are assumed to have a positive relationship and in Colum 2 , the relationship is allowed to vary between .20 and .50 .

Cólum 3 Because the literature suggests that DECENT may have a posftive or negative relationship with ADOP. for the sake of completeness, correlations between the two variables are allowed to vary from -.50 to. +.50 .

Column 4 This column presents the partal correlations between MACS and ADOP under the various assumptions of Columns 1,2 , and 3 .

Column 5 This column shows the differences between zero and if istorder correlations. Differences are calculated by . subtracting Colunn 4 correlations from Colum 1 correlations.

Column 5 in Table 5.11 shows that partial correlations can te very different from corresponding zero-order correlations. For example, if the correiation between MACS and DECENT was +.50 and the correlation : between DECENT and ADOP was +.50, holding DECENT constant would Increase the observed correlation between MACS and ADOP from -.20 


\section{$\because$}
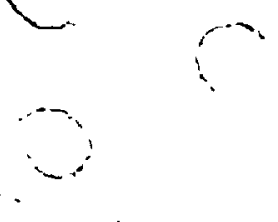

to .60. In thls case, decentralization could be sald to have e large. Impact on the observed relationship betweerivics and adoption

In the simulation of Table 5.11."differences between zero and first. order correlations range frow .00 to .40. Looking at the actual results, the largest difference between zero and firstorder correlations 15.05 imtable 59 and .03 in Table 5.10 If we are to use simulation differences as ar yardstick, observed differences between zero and first-order correlations in Table 5.9 and 5.10 are very small Thus, the simulation supports my earlier statement that controlling for MANPOS has itttle effect on the observed relationship between MACS and ADOP. And the simulation supports the contention tha: Hypotheses 5 and 6 cannot be rejected. I must conclude that the relationship betwen MACS and adoption Is independent of decentralization 20

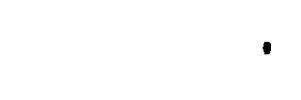

20 An analysis of the survey data reveals that there are no - Ignificart correlations between the macs and decentralizetion varlables and becween che adoption and decentralization varlables ln ceras of the definltion useduln the eloulation. all zoro-order correlations ore onall. 
Iables.11

Staulation of Partiol Correletions

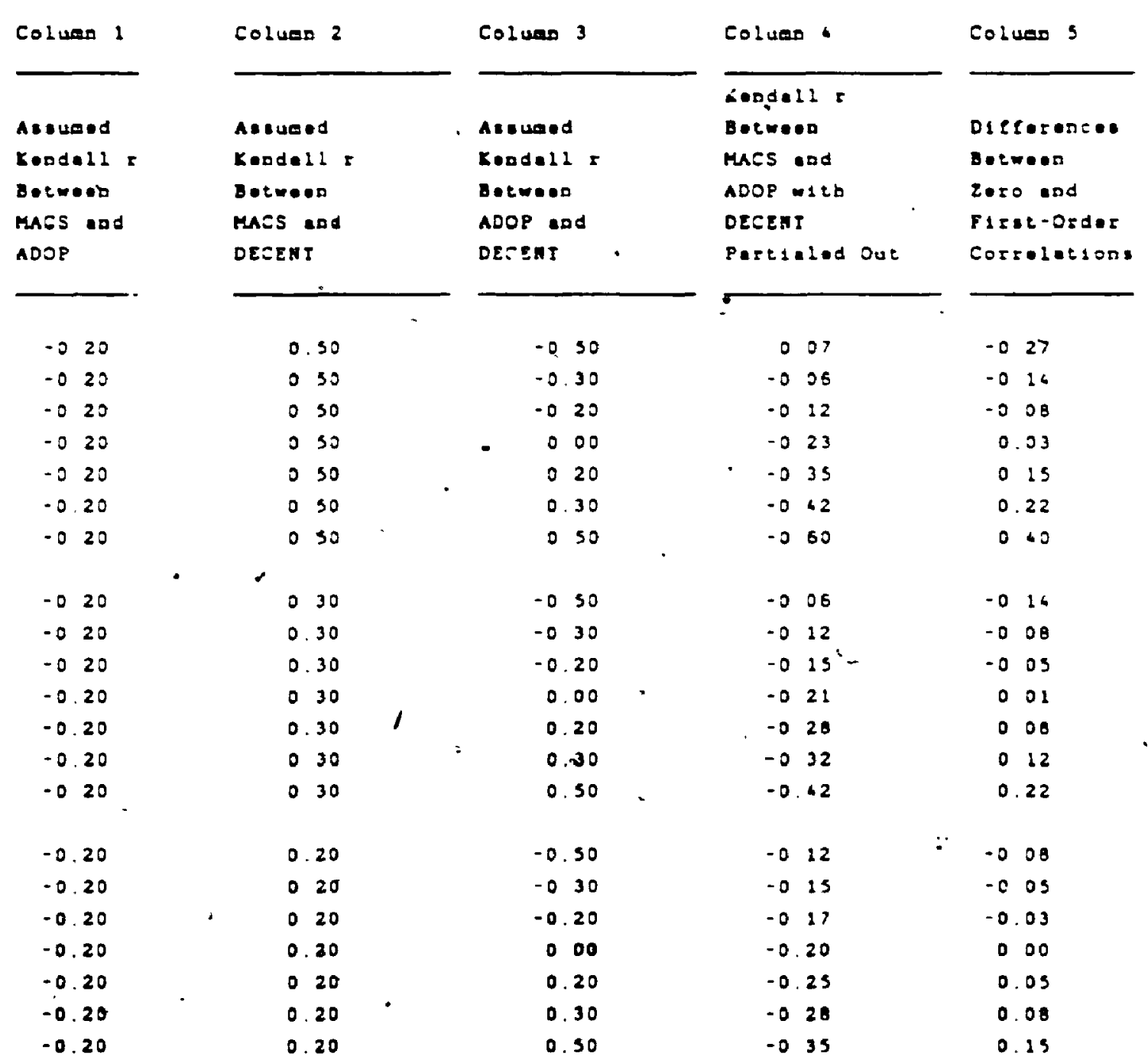

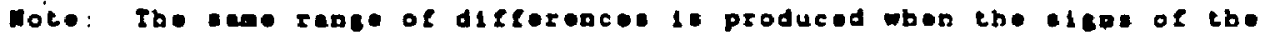

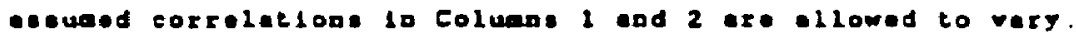


V.B.Respondent-Rank and Mode 1 B

In Chapter four. I stated that the validity of the decentrallzation measures depends on respondents holding roughly equivalent positions in theit firms. As noted in Section, II of this chapter, respondents differed on the two measures of hierarchical position. Manposif and MANPOS2F To complete the analysis of Model 8, I wust theretore check for interactions between the DECENT and Matipos variables Table 512 shows there are no significant correlations between DECENIM and the two variables measuring respondent rank It is not surprising that the. DECENT2M measure is not correlated with hierarchical level because. DECENT2M is more a measure of firm culture than of respondent responsibility and authority However, it is a surprise that DECENTIM does not-correlate with respondent rank One would expect a manaper's particlpation in declsion-making to be related to his or her position in the firm,

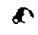

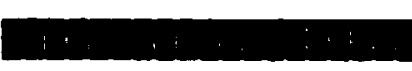

Table 5.12 .

Correlations Between Decentralgzation and Hierarchical Vartables

MANPOSIF

DECENTIM

$\begin{array}{rr} & 11 \\ \text { n } & 28 \\ \text { p } .58\end{array}$

$+$

\begin{tabular}{|c|c|c|c|c|}
\hline \multirow{3}{*}{ DECENTIM } & \multicolumn{2}{|l|}{ MANPOSIF } & \multicolumn{2}{|c|}{ MANPOS? } \\
\hline & 11 & - & & 04 \\
\hline & n 28 & & $n$ & 28 \\
\hline & P. .58 & & $p$ & 86 \\
\hline
\end{tabular}

DECENT2M $-22 \quad-28$

$\begin{array}{lll}n & 29 & \text { n } 28 \\ p & 26 & p\end{array}$

P $26 \quad$ P 16 
A clóser look at DECENTIM suggests a reason why the measure "is Independent of MANPOS1F and MANPCS2F. A correlation table of the 15 items in DECENTIM suggests, and a factor analysis confiras, that the measure has two dimenstons. Nine ltems load on "participation in strategic decisions" (DECENTIA), and 5 ftems on "participation in tactical issues" (DECENTIB). 21 This is not surprising. Recall that the icems in DECENTIM were culled from lists of strategic and tactical decisions for which manufacturing managers are responsible. Table 5.13 shows that DECENTIA and DECENTIB are related to respondent position. but in different directions. Mangers who score more highly on participation in tactical issue (DECENTiB) hold lower rank. Mangers who score more highly on participation in strategic issues (DECENTIA) hold higher rank. It appears that DECENTIM is not-related to respondent position because it has a bullt in control of respondent level.

Since both DECENTIM and DECENT2M are free from respondent rank bias,

21 One lten, "particlpation In setting quallty levels and procedures" is not related to efter factor. Because of che inportance of quality in the autometive industry, many firas have a separate quality control department. 


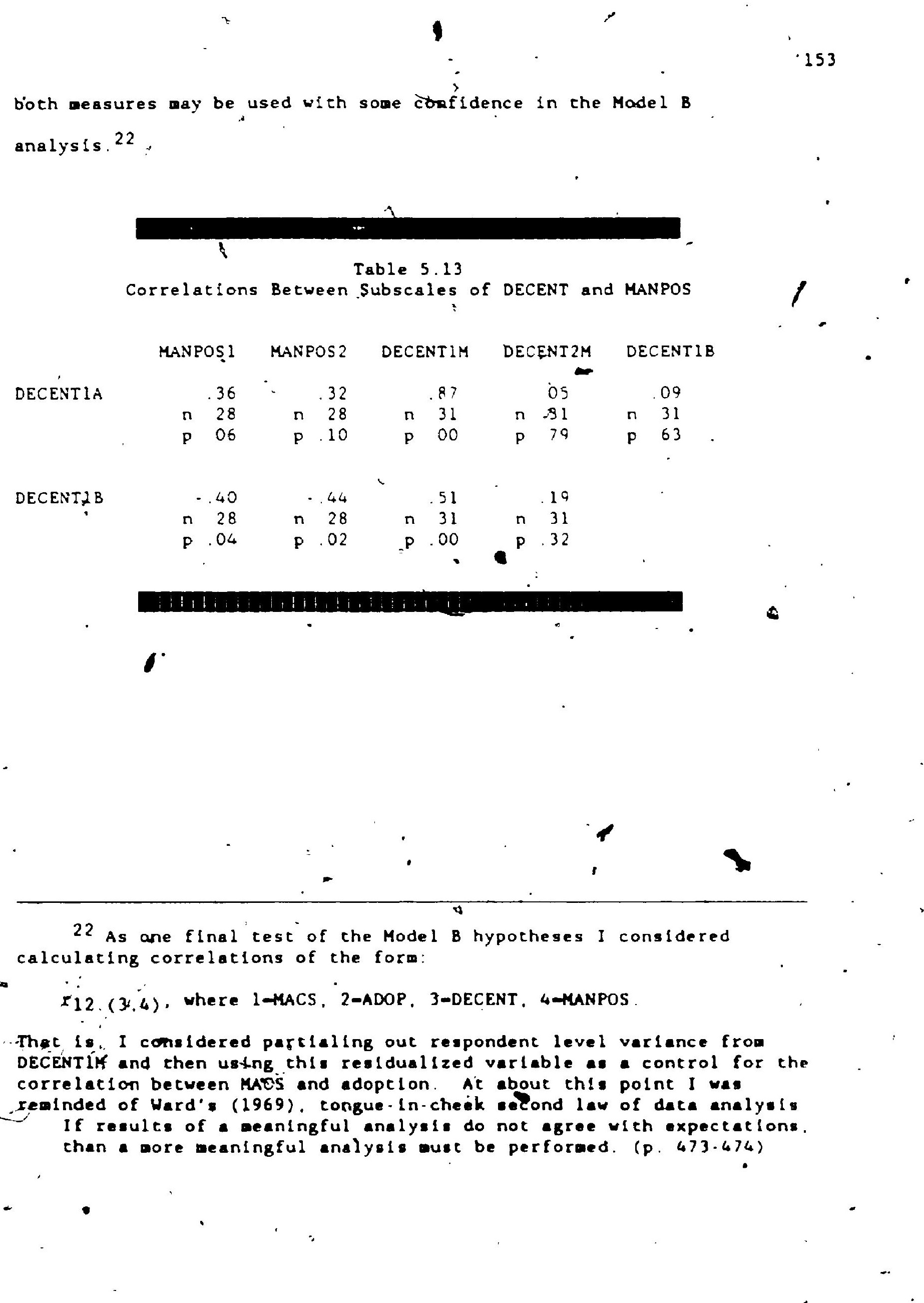




\section{Sectlen VI: Chapter Sumary}

This chapter began with a discussion of the appropriateness of the sample and of the measures of MACS, decentralization and adoption of flexible automation. Insights frod the face-to-face interviews of plant nanagers were especially helpfuly in resolving salidicy and relfability issues. Analysis of the data followed, and I found that

1. The greater the longest time perjod for budget reports and objectives, the greater is the adoption of flexible automation.

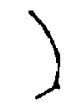

2. The length of the shortest time period for budget reports and objectives is not related to the adoption. of flexible automation.

3. Use of accounting measures for exaluating managers and. emphasis on financial arguments for justfying new investmeñts are not related to the adoption of flexible automation.

4. Plant managers do. not have difficulty in quantifying costs and benefits of flextble automation find, in any case, difficulty in quantification is not related to adoption of flexible automation.

5. Decentralization is not a factor in the relationship between Macs and adoption of flexible autonation.

I will expand on these findings in Chapter SIX. 
This chapter is divided Into four sections. Section I re-examines the six hypotheses in the light of the personal interviews and plant visits and offers some explanations of the statistical results. Section II suggests some opportunities for future research and section III looks at the assumption that flextble automation is "good" for firms is Finally, Section IV makes some recomendations for managers and researchers, and brings the thesis to a conclusion

\section{Section Li Incerorecing the Siacisticaj Resulis"}

In Chapter Flve. I presented the mail survey results along with the interview data that could be coded or quantified. In this section I will present some of the more subjective conclusions draw from the personal interviews and plant visits. The se conclusions should be. incerpreted as theories that might explalp the statisticat results.

I will begin by marshalling evidence that supports the resules of the stiatsistical tests of each of the-Hodel $A$ and $B$ hypotheses. For all but one of the hypotheses. I w1ll suggest reasons why the null was not refected. The exception is $\mathrm{H} 2$, the tioe horlzon hypothesis. For H2, I will suggest mechanisms by which budget targets and reports may impact on adoption. 
I.A. HI: EMFEVL not related to ADOP

Almost all the respondents sald they wanted wore flexible automation for their plants. Many of the mangers noted that, the key to getting the flexible automation they wanted was to have a good "track record" "Heavy hitcers" or "managers with good batting averages" were aore likely to apply for, and get, advanced technologies. By ltself. emphasis on MiCS for performance evaluation may not be related to adoption of flexible automation But the interaction term. (EMfEVI $x$ actual performance on MACS measures) may be related to adoption. Consider a situation where MaCS measures are not used to evaluate managers. In such a situation te may be difficult for a manager to demonstrate competency. A history of good performance as recorded by the accounting system may make ft easler for manegers to get ne. machinery and equipment because they are able to demonstrate they have done well with what they have been given in thef past. ${ }^{*}$

The relationships among adoption, use of MACS for scorekeeping, and managers' track record, may be affected by other contingencles. For example, the time span of performatice measurement may be related to the development of track records. The automotive industry is cyclic in nature and the longer the time perlod over which evaluations are made, the better can top aanägent assess performanee of plant ianagers. Of

I See Plnches (1982) for a dlscussion of how top managenent perceptions of project sponsor's record affects capltal budgeting critoria and threshold levels. 
course, this assunes top managers are sophistlcaced users of MACS.

Based on the coments of plant aanagers. that would be a fait assumption.

Thus, HI may not have been rejected because the relationships among EMFJST and ADOP variables may be confounded by a number of factors Future research should test whecher managers of plaris with high levels of flexible automation are evaluated in terms of MaCs objectives. over long periods of time, by superiors who factor olt industry performance from manager al performance

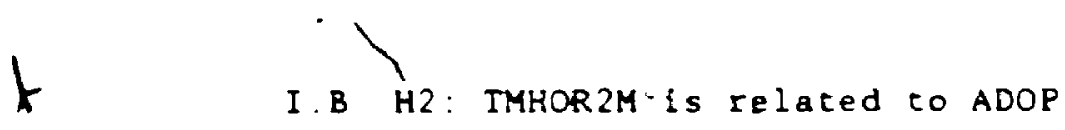

I have already referred to the possibllity that long-terabudget targets and reports may assist managers in creating track records But an explanation of the relationship between TMHOR2M and ADOP wust also consider managerlal motivation and planning resources

Many managers stressed that successful adoption of flexible automation occurred only when new technologles were lmplesented in confunction with new programs (le. the manufacturing of new parts). Atceapts. to add flexible automation technologles to un-going programs often falled. I hypotheslze that managers with longer MACS tiae horlzons are more likely to be aware of and concerned about the econonics of future production and thus more likely to consider Incorporating flexible automation In new programs. For example, In aaking an Input to hls 
film's bid on a new part for GMC, one plant manager, who had long-range budget targets and reports, discovered that the only way he could reconclle rising labour coses with GMC's expectations that prices decrease each year of a long-tern contract, was to apply flexibie automation to the manufacturing of the part. The firm made a bid on the port using costs based on flexible automation, won the long-term contract, and adopted the flexible sutomation Competitors for the GMC contract had shorter MACS time horizons and did not address the issue of rising costs and falling pricet. Their bids were based on simple extrapolations of current prices and current technologies. The point is that managers with longer MACS time horizons may be more motivated to do "what $1 \mathrm{f}^{\prime}$ analyses and so be more likely to adopt and sugcessfully implement flexible automation. At the same time, these managers may have more resources to conduct long-range planning. Where long-term objectives, budgets and evaluations are the norm, it may be more acceptable for managers to commit time and money to the planning process. As one high-adopter put it: "You have to plan to have some time to plan." In thls respondent's firm, lower level managers hold regular strategy and planning sessions on Saturday mornings. Contrast - thls culture with the one in many low-adopting frus where anagers spend little tlme making long-term plans and are not expected to "waste time" worrying about the distant future.

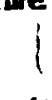

In the Intervlews it was discovered that one managers who iad reported high scores on TMHOR2M had in fact only nominal commitments to their long-tern budgets and objectlves. The managers in these flras had. 
little confidence in their long-term plans which were werely pro-forma extensions of thefr current budgets and objectives. Understandably, they spent iftele effort producting and using thelr plans. The already significant correlation between TMHOR2M and ADOP night be even larger If the firms with pseudo-plans were to be withdrawn froo future analyses.

I.C. H2 TMHOR3F not related to ADOP

The fact that payback criteria were not related to level of adoption may be explained by the ubiquity of short-term payback criteria. Managers cited three réasons for utilizing short payback périods to assess investment proposals. Proposals, especially proposals for larger investments are time-consuming. As one manager put it, "I' not going to spend hundreds of hours working on a proposal I know is going to be shot down." 2 To avold wasting time, managers only request monies for projects they know wlll be approved: projects with quick paybacks. A second reason managers use very short payback criteria is because they belleve their superfors may be reluctant to continuously upgrade equipment:

If you're not tough on your payback and your conpetition is. you'11; be in trouble. If a better nousetrap cones along. you won't be able to get that better mousetrap because you've got this plece of equipment and you're walting for your five year payback on $1 t$. So this new mousetrap's out there and you can't

2 Managers' coments about supporting only those'projects. they know in advance will be approved conflro the viow that MACs" are. especially important in the early (Initlation) etages of capital. ". budgeting (Bower 1970, PInches 1982). 
get it because you've got the old model and you still have to rationalize it.

A third reason for short paybacks is risk aversion. Several managers described personal strategles of avolding projects with aarginal paybacks. They stated they would not propose or support projects that marginally exceeded the formal payback criterla. In other words, given the cholce, managers preferred to "go for the sure thing" and the "big winners."

Short-term payback thresholds almost certainly impede Investment in advanced technologies, but for the reasons cited above, almost all managers use very short payback criteria. Because there is so little variability in TMHOR3F, this variable has little explanatory power for the ADOP variables.

I will conclude this discurston of payback with a comment related to the recomendation, often clted in the literature reviewed in Chapter Two, that top management can promote adoption of flexible automation by increasing the time perlod of formal justification criteria such as payback. In Chapter Five, I made alstinction between fornal payback criteria (TMHOR3M) and personal payback criterla actually used by managers (MAHOR3F). ThIs study has shown that personal payback criteria are not related to level of adoption. That is not to say that Increasing formal payback thresholds would not prosote adoption. It would be interesting to study changes in personal payback criteria and In adoption of new technologies" In flrms whose top management has lengthened the formal payback requirenents. In the same veln, 
increasing the MACS time horizon (TMHOR2M) alght also be considered as a way of lengthening personal payback criterla. As Table 5.4 shows. TMHOR2M is the only varlable signifianty correlaced with MHOR3F $(p-.09)$

\section{I.D. H3: EMFJSI not relaced to ADOP}

I will discuss three possible reasons for the low correlations anong ADOP and EMFJST variables. First, the reason for the low correlations, between EMFJST2F (importance of payback in jugfification) and ADOP may be similar to the une used in explaining the insignificant relationships between TMHOR $3 F$ and ADOP: most of the managers considered payback to be very important in justifying investment proposals and therefore high and low adopters could not be distinguished by scores on EMFJST2F. Second, EMFJST2F and EMFJSIIM (emphasis on financial issues in justifying flexible automation). may figure only in the adoption of offensive integrated flexible automation. And third, EMFJSTIM may be a poor measure. The two latter rationales will be discussed in greater detall. The explanations which follow are theorfes, and efther, nefther, or both of them may be true or partally true.

\section{I.D.L.DIfferent Types of Investments}

In Chapter five, I noted that Installations of flexible automation way be-clessifled as Integrated or stand-alone and that most of the. 
Installations in this study were of the latter type and thus relatively siaple and fnexpensive. In discussions with anagers, another Investment dichotomy became evident: offensive and defensive Investments. Here is how one manager distinguished between the two types:

qefensive invescments are chose we have to make if we want to stay in the business we're in now. Offensive Investments are for new business and we exanine the payback on those very carefully

An example of a defensive investment is ine purchase of a robot to replace a human operator in a paint foom bocause the room's environment does not meét government health and safẹty standards. An example of an offersive investment is the purchase of computerized equipment for testing a new part to convince customers that the firm is serious in its bid to manufacture the part. ${ }^{3}$

It may be that EMFJSTIM and EMFJST2F are factors in adoption onty when the investment being considered is an offegnsive investment and involves purchase of integraced automation technology. Investment proposals of a defenglve nature, whether for integrated or stand-alone achinery. require litcle justiflcation. And, Justiflcation of an offensive investment in stand-alone machinery is falrly stralghtforward: such an investment would represent elther a replacement for curtent machinery or alnor extension of current business. However, an offensive Investment in integrated flexible automation is atrategic decision. and requires much more effort to fustfy. It may be, as, shown in

3 Simflar offensive-defensive dichotomies are noted by Bessant (1982) and Brealey Hyers (1986). 
Figure 6.1, that EMrJst is a factor only in the consideration of offensive investments in integrated flexible autoation.

Figure 6.1

Role of Macs in Justifying Investments

Integrated Machinery

Stand-alone Machinery

\begin{tabular}{|l|l|}
\hline $\begin{array}{l}\text { EMFJSTIM Is } \\
\text { not related to } \\
\text { ADOP }\end{array}$ & $\begin{array}{l}\text { EMFJSTIM is } \\
\text { related to } \\
\text { ADOP }\end{array}$ \\
\hline $\begin{array}{l}\text { EMFJSTIMis } \\
\text { not related to } \\
\text { ADOP }\end{array}$ & $\begin{array}{l}\text { EMFJSTIM is } \\
\text { not related to } \\
\text { ADOP }\end{array}$ \\
\hline
\end{tabular}

Defensive Projects Offensive Profects

Figure 6.1 suggests that the relationship between financial justification and adoption is confounded by type of project. A worthwhlle question for future study would be: Is financial justification related to the approval or rejection of Integrated, offensive Invéstments in flexible automation? Research that attempted to answer this question would require a saple of plants whose 
management has consldered offensive Investuents in integrated machinery and some of whom adopted the technology and some of whom did not. 4 9

\section{I.D.2.Senente Problens vith EHFJTIX}

In the interviews, the two most often cited reasons for adopting Elexible automation were to "Improve quality" and to "Increase capacity." However after some probing, it became obvious that when some managers talked about quality improvement they really meant lowering costs by reducing spollage, weste and scrap. Typically. these managers manufactured products that require expensive unrecyclable materials. 5 . Other managers meant "improved customer relations" when they talked about quality. These managers felt the adoption of flexible automation demonstrated their comitment to quality:

The customer says, "You mean to tell me you can't find a single reason to embrace this modern technology that everybody is getting." Well, the answer is obvlous. If everyone else says It's a good 1dea, they can't all be wrong. Surely you can get some [flexible automation] too.

There are similar Interpretation problems with "capacity." Consider. for example, the manager who stated that asjor investnents in flexible autonation had been Justifled because they "Increased capacity without

4 As described In Section II of Chapter Two, Woods et al. (1985) studied flfos that approved and flrms that rejected investments in Integrated flexible autonation. However, the authors made no distinction between offensive and defensive proposals.

5 Material costs ranged from $22 x$ to $70 x$ of total costg and averaged 49x. Even plants in the same group differed widely on materlal costs. For example, reaction-injection molders in the plastics group have high aterlal costs because they cannot reuse materlal after It has been injected into mold. Thermoplastic. injection.polders, on the other hand, can recycle scrap and spoflage. 
increasing the number of workers." Further discussions with this manager revealed that by Increasing capacity he weant not only Increasing volume but also widening product mix (le. Increasing flexibility). And since labour costs were essentilly fixed, and since his plant was a cost centre, by Increasing volume this manager was able to reduce the per part cost of labour.

Since quality and capacity both have financial implications, managers may have had trouble interpreting some of the items in EMFJST1M. This may explain the low reliability of EMFJSTIM and the concomitant low correlations between the variable and ADOP.

I.E. H4: DIFQUN not related to ADOP

As reported in Chapter five, tha managers in this study generally disagreed with the proposition that it is difficult to quantify the costs and benefits of f'exible automrtion. The interviewees seemed to be quite happy with their MACS and with their accountants.

\section{$\bullet$}

That satisfaction can be partilly explained by the fact that managers did not have th depend solely on their MACS for generating the numbers. required to justify flexible automation. For example. one manager ordered englneering tiae studles of a plastic molding operation and found large variances in the cycle, time of the manually operated. machines. The manager was able to fustify an Investment in automation 

- there was so 1:ttle. evidence of conflict between these two groups in regards to the Investment process.

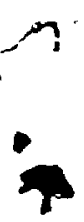

As shown in the Table 5.11 simulatlon, if controling for DECENT was to affect the relationships between EMFEVL and ADOP, and EMFJST and ADOP. DECENT would have to have at least a "medium sized" correlation with I those variables. This was not the case and Hypotheses 5 and 6 could not be.rejected. I have no explanation for the low correlations between DECENT and the MACS varifas, but I can, speculate why DECENT and $A D O P$ vere not more highly correlated.

As recounted in Chapter One, decentralikfion may have an Impact on adoption only when elther top managers or lower level managers are opposed to a particulari innovation. In this study managers and their supervisors generally held positive attitudes towards flexible automation. 6 In one or two cases respondents were opposed to imediately installing flexible automation because they felt their flrms lacked, the necessary technological and organizational Infrastrutcures. 7 However even these mana,ers supported the adoption. of computerlzed machinery on principle.

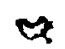

6 In their study, Cohn \& Turyn (1984) found that a "relative absence of conflict over adoption decislons" was a ajor factor in reducing the lmpact of decentralization on adoption of new technologies.

7 HIIl Dimnik (1986) discuss the organizatlonal and I technological infrastructures needed for successful implenentation of flexible automation. 


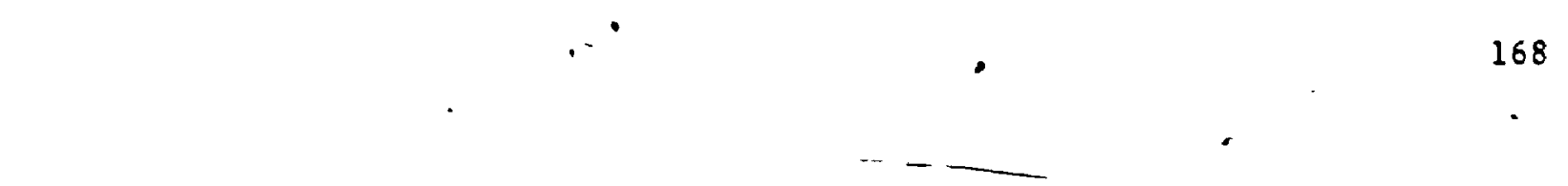

Section II: Future Research

Throughout Section I. I comenfed on the need for more research on particular aspects of the MACS-adoption relationship. "In particular. rẹsearch is needed to discover:

1. If interactions between MACS and other wariables are related to the adoption of flexible automation.

2. If changes in time periods of budget targets and reports, and changes in formal justification criteria, affect managers' personal time horizons and decision heutistics and, if so, if changes in personal time horizons and decision heuristics affect adoption of flexible automation.

3. If emphasis on financlal justification impacts on decisions to invest in offensive. integrated Nexible
automadion.

Future research of the relationship between MACS and adoption of

- flexible automation would have to address the problem of operationalizing EMFJST. Though EMFJSTIM meets minimum standards of reliablitity and construct valldicy, the instrument, could clearly be Improved and the discussion of $H_{3}$ in section I gives some insight as to

- how this wight be accomplished. Future research should, of course, be conducted on samples from other industrles. I will resist the traditional exhortation that future research be conducted on larget semples. As long as the reseatch methodology Involves, as it should, plant visits. and face-to-face intervlews, lt wlll be difficult for Individual researchers to survey simples auch larger than 30. 


\section{- In addition to the research agenda pregented above. two other hypotheses might be addressed I future studies.}
Hypothesis: Sophistication in the use of MACS, and the "fineness" of MACS, are not related to the adoption of flexible automation. :

- It is my impression that high adopters of flexible automation have "finer" MACS and are more sophisticated users of these MACS than low adopters. I iuse "finer" in the same sense as Ijiri (1967). High adopters may have more numbers to work with. Their MaCs may convey more information because costs are broken down Into smaller categories Paradoxically, high adopters may also interpret their "finer" MaCs with greater skepticism. They may use the numbers generated by their maCs but they do not use them blindly. In this study, several of the htghadopter mangers were former accountants. They had played a role in designing the MAC̣S, and were fully aware of the potentials and pitfalls of their systems. These managers felt thelr knowledge of accounting. had helped them acquị re and manage advanced technologles. Alluding to the increasingly sophisticacied techniques needed to manage increasingly sophisticated technologies, one former accountant sald:

The old-tlge plant managers were poople who rould yell the loudest and beat everyone up but now ro don't need people who can hout and $f i g h t$, you need people ho ire good financlal gariagers.

In confunction with the plant visits. I collected eamples of each firm' accounting reports. An interestipg future project would be to * operationalize "flneness" and then test whicher the fineness of the 
reports used by plant managers is correlated with adoption of flexible autonation.

Hypothesig: The use of growth-oriented MACS is not related to the: adoption of flexible automation.

L.

Many of the lowrech plants in this study were being managed as "cash cows." Some of these plants had generated profics for decades with very litele investment in new machinery and equipment. Hringing every last drop of profit from capital investments may have been an appropriate.s dategy for the automotive industry when it was in the. mature Rhase of the product lifecycle. However, the automotive industry is now "dematuring" and players in the Industry need strategies wore appropriate to the growth phase of the product Iffecycle (Jones 1985). Changes in strategy should be matched by changes in MACS and changes in management personnel (Govindarajan 1987).

Management of several of the firms in the study were abandoning thel cash cow strategies and undertaking to invest more aggressively in new technologies. It woild be interesting to see if the MaCs of these firas and otherg like them are changing to accomodate the new stratgles and circumstances, and if the new strategles and systems affect Investment in advanced tochnologies. 
Section IUL: Assumptions

I described some of the potential benefits of flexible autoation when

I presented the rationale for thls research in Chapter One. The

findings of this study ay be of academic interest whether or not the benefits of adopting coriputer operated machines outweigh the costs.

however costs and benefits are defined. But from a managerial point of view, if there is re adtheage in automatson, there is no interest.

It is not possible for a cross-séctional study to demonsţrate whether or not dutomation is "good" for "firm. Even if "betcer" were defined as "more profitable" and firms with more fléxible automation were found to be more profitable, that reguit might sioply mean that profitable firms have more resources to spend on flexible automation. 8 Howeyer. If we were to assume that profit is an appropriate surrogate for a number of factr. that define success, then the test of the value of flexible autoration would be whetier or not it enhances firm proflt over some fairly long period of the. Restated in tes most fundamental ford, the question is whether more highly atomated firms have a beter chance uf survival than firms wh less automatior.

- 8 "Good for the firm" can be defined In many ways (Lowe G Chau 1984). As 'I wlll shorty show, there is a epate of current articles" ouggesting flexible cutodition may not be all that good for firms. critics of autoation are using the wae messures of "goodness" that vere critlgized for ratarding the adoption of flexible automation. For ixample, a few yeare ago. top manigenent of General Mocors was crlticlzed for belng too enamored with short-ter profles and thus slow In cdopting flexible autonetion. Now that the conpany has invested heavlyy in advanced technologles, critlcs argue the stategy is a bad orte becauseshort-tern profits are down. 
Recent articles have questloned whecher flexible acomation is profitable. Arnholt (1986) claims that the automotive industry's "high-tech honeywoon is over" and Winter (1986) states that high-tech, which was "pumped up in the late' 70 s and early' 80 s as the Superman to save" the North American automotive Industry" "hasn't come close to meeting the extraordinarily high--and often unrealistic.. expectations." An IMEDE wail questionnaire study of 128 plants in 30 different countries concludes:

In perhaps the most controversial results of the study, 'there appears to be some doubt about the worth of some aspects of the drive for Increased automation. Given the specific character of the results, it appears that for new technology to be effective it must be well integrated into the process flow. Heavy investments in just any technology do not seem to lead to higher productivity gains. This finding supports recent press articles which caution against too much devotion and dependence on technology as a cisre-all for disappointing manufacturing performance. This is clearly a subject that requires careful study (IMEDE 1987).

Plty the poor manager who a short time ago was urged to adopt advanced technologies and is now told to be more cau'tous and not to "automate - for autoution's sake."

hy plant cours convinced ae of the absolute value of flexible automation. The visits showed ne that even when the benefits of automation are less than expected, there are stlil many benefits. To expand on thls point, I will briefly contrast one low adppter with one high edopter in the sape product group. . To preserve fonfidentiality, I 1 w11 not naise the group. 
Lor Adopter Plant

The first thing that strikes a visfor to the plant is the nolse. The machines are loud but louder still are the radios blaring out froa several work stations. The second thing one notices is that the plant is dirty. The floor is fllthy with ofl and waste material. The machinery looks old out it is not. It is dirty and unpginted. In one corner of the plant a group. of people look through boxes of the previous night's production. Workers had not notlced a flaw in the process and so the shift's entire output is being manually inspected. There is a sense of urgency in the volces and manners of the nanagers and supervisors. A late shipaent to one custoner has closed down the custoner's assembly line and a second shipment is running behind schedule. To try to prevent delivery problems. the firm is constructing a buslding mext to the plant to store finished product. The plant manager admits that relations with workers are poor. One of the reasons is that workezs are hired and laid off with fluctuations in the indusery.

\section{High Adopter Plant}

The plant is noisy but not ancomfortably so. The floors are cleari and though the plant is small there seems to be lots of room. The plant walls bave been recently palnted. The machinery is highly automated and workers spend wost of their time examining output as it is produced. . Everything seems to be under concrol. Workers and managers appear to be.cool and calm. The plant is undergolng substancial renavations lo order to ratlonalize flow of raw materlals and finished product. The plant manager claims that relations with workers are good. Workers are consldered to be skil led and skilled labour is expensive to find and train. When automotive sales drop, the workers are kept busy with stepped-up manufacture of nonayfonotive. products and with machjne and plant alntenance (eg. painting walls?. A number of plant people are cobop students frod a near-by unlversity. They are supervised by the peranent workers. The plant aanager clalos these students bring in information on tate-of-the-art manufacturing processes and serve as an-threatening means of in-house tralning for the permerient otaff.

I have chosen plants et polar extremes to lllustrate ay point, but to varying degree; the more hlghly automated plants seaned to be quiteter and cleaner than the loss autonated plants. The hlgh adopter plant? were dore likely to be undergolng renovations to inprove product from 
and were more likely to anufacture non-autonotive products in acjltion to automoifve parts. High adopter anagers and workers seemed to be calner and more purposive and. perhaps as a consequenç of their environment, more. satisfied and complted to thelr plants, and companies.

-

One of the arguments against emphasis on technological innovation is that "people, not machines, are the answer" to productivity problems -(Arnholt 1986). My impression 1s that adoption of flexible autamation has a direct impart on the efficiency of the manufacturing process and an indirect one through increased worker comitment and motivation. Furthermore, the installation of flexible automation seems to serve as a catalyst for improvements in work flow and product design. 9 Even when managers felt the Inftial installation of flexible automation to be a failure, they argued that the experience had given them new Insfghts and motivation to Improve the production process.

That is not to say that flexible automation is without its drawbacks. On the downside, major investments in advanced technologies have proven to be nore expensive than expected. In several publicly held firms. high adopter plants were reporting low returns on assets employed and In sone cases were being divested because thelr top managenent felt they could achieve better refurne elsewhere. It aay be argued that in these stcutions the MCS is undervaluing the high-tech planta. While

9 Ayres and Miller (1983) present a model of how adoption of advanced technologies can catalyze organizational and technological change. 
this may be true, and it may Illustrate a shortconing in the Macs,ia more likely explanation of the divestment strategy is demands of shareholders and fears of take-nver. If this is the case, then the problem, If there is one, may ile with external reporting or financial accounting and not internal Maes.

A wore prosalc problem_facing adopters of new technology is keeping their high-tech machinery running. I rarely found flexible automation. especially integrated automation, tr be fully operational during ny visits. In describing his integrated syster one manager noted:

We have five or $\$$ Ix robots and PLCs in that cell and each machine is up $95 \%$ of the time. But all of them have to be working for the cell to work. So if you compound all the downtimes, the cell is only working $60 \%$ of the time. Which is still better than the uptime on our old machines, but less than we expected with the new equipment.

Without.being too gltb about the utilization problem, in most cases where uptime was an lssue, the technology was new to the plant. As experlence with the new machinery increases, so too should uptime.

Section IV: Recommendations and conclusion

ThIs study almed to answer four questions:

- 1. Is the use of account 108 measures to evaluate performance related to the adoption of flexible autonation?

2. Are the time horlzons Impliclt in MACS related to the adoption of Flexible automation? -

3. is the use of flnancial criteris in evaluating cepltal budgeting proposals gelated to the adoption.
of flextble automation? 

4. Are difficulties in quantifying flexible autoation benefits related to the adoption of flexible autonation?

The answer to quegtions 1,3 and 4 is a quallfled "no." The study shows that the characteristics and uses of MACS addressed by those questions are not related to adoption. Only question 2 may be answered by a qualified "yes." The length of tiwe incorporated in budget targets and reports appears to be relaced to the adoption of flexible - automation.

The outcomes of this study are somewhat unexpected considering the widely held view that accouticing systems are impeding investment in advanced manufacturing lechnologies. However, the finding that MaCS time horizons impact on adoption may be seen as supportive of the normative literature which recommends that top management employ accounting measures and procedures that reflect the long-term objectives of their firms. Though this study looked only at a small 6ample of managers and plants, the findings may apply to the adoption of stand-alone flexple automation technologies in the automotive parts Industry as a whole, and perhaps to investment in advanced technologies in North Amerlcan manufacturing firas in general. But even if one were to dispyte the clains of generallzabillty, the results of this study challenge the allegations againgt aragenent accounting. At the very loast, this tudy should prompt further omplrical research in the area of MaCs and adoption of new technologies. 


\section{IV.A.Recomendations for Top Management}

Throughout this thesis I have presented evidence supporting greater investment in advanced manufacturing technologies. The plant visits convinced me that top managers of North American manufacturing firms should promote investment in flexible automation within their firms.

This research indicates that net much need be changed in current MACS in order to create a more posicitue environment for adoption. The key is to extend the time horizon of the MACS. A first step would be to set budget targets for periods longer than one year. For example, rather than setting only wonthly or yearly profit targets, top management could set profit targets for two or even'three year periods. A'second, related step, would be to provide managers with feedback on their performance on long-range targets. For example, the MACS might generate reports that track performance over several years: two or three year budget spmmarles rather than annual reports.

Top management must support the extension of the MACS time horizons in two ways. Flrst, lower level managers mugt be rewarded on the Ir performance on long-terw object!ves as reported in formal accounting reports. Second, lower level managers must be glven resources for planniug, Providing managers with. time, staff, and training for long. range planning should promote technological innovation. 
Top management who implement these recomendations will have standards agalnst which to judge managers" "track gecords." Managers with good "batting averages" will be more confident in Initiating change and will be more likely to recelve approval of their investment iniciatives. If these recumendations were adopted, top management can spend less time evaluating investment proposals and nore time evaluating sponsors of proposals. And instead of conducting post audits on an investment by investment basis, top management can examine the portfolio of

: investments controlled by each manager. Longer MACS time horizons may eventually lead tn a more decentralized organizational structure where managers closest to the technology have greater responsibility for Initiating and implementing technological change. In the end, this may result in dore aggressive investment in advanced technologles.

I would point out that in recommending only "minor" changes to MACS, I am responding to those who advocate that major changes in MACS are rneeded to promote adoption. There may be any number of reasons why top managers wish to review and alter thelr MACS. My argument is that top managers should concentrate on time horlzon. issues if thelr objective, is to create a more positive environment for manufacturing innovations.

\section{IY. B. The Need for Fleld Research}

Having iready ande leveral spectflc proposals for future research i would now stess the rieed for field research. While mall surveys have some definlte uses and obvlous advantages, thargesults of mall surveys 
must be checked against the findings of fleld research. There are ( insights and understandings of MACS that car only be obtained through interactive and apen-ended research methodologies. In conducting the personal interviews I came across a good example of how on-site observation of management practice might inform the normative licerature.

The normative literature on the implementation of advanced cechnologies argues that since the competitive environment is changing. and since production processes are changing, there should also be changes in MACS. It is presumed that managers are wasting resources on, and are being misinformed by, obsolete MACS. An often cited example of an obsoiete accounting practice is the allocation of overhead on the basis of labour hours or dollars, even when laboix-costs are a small . proportion of total costs (Seed 1984). Mail surveys confirm that many firms st111 allocate overhead to labour (Schwarzbach 1985), and that many managers still spend considerable tloe and effort investigating labour varlances, even when labour costs are a small fraction of total $\therefore$ costs. These results could be, used, to suppore the proposition that the animportant labour costs and make less than optimal decisions (Kaplan $i$ 198\%b).. And yet. In thls sample, the anagers who analyze labour rarlances where'labaur is only $5 x$ to $10 x$ of total costs, do not use their Macs nalvely. Because of thulr experience with-their manufacturing process and an understanding of the relationship between the process and accounting numbers, thesè managers make gond use of 

budgeting criteria should be lengthened, that less enphasis should be placed on fpancial criteria in justifying investment in flextble autöation, and that less easily quantifled costs and benefles of flexible automation should be considered in appraising investoent proposals. The validity of these prescriptions was tested in a sample of 32 GMC part suppliers. Self-administered quesL:onnaires and face- $\theta$ to-face incerviews of plant managers were used to assess characteristics and uses of accounting systems and levels of automation. Statistical tests showed that the only varlable significantly correlated with automation is the "long-term time horizon of budget targets and reports." The results were interpreted in the Iight of plant manger interviews and plant tours. Rather than making major changes in their accounting systems, top management wishing to promote investment in new technologies, were advised to extend the time horizon of their MACS. The thesis then concluded with a discussion of future research opportunities and a call for more field research. 


$$
3 \text { of/de } 3
$$

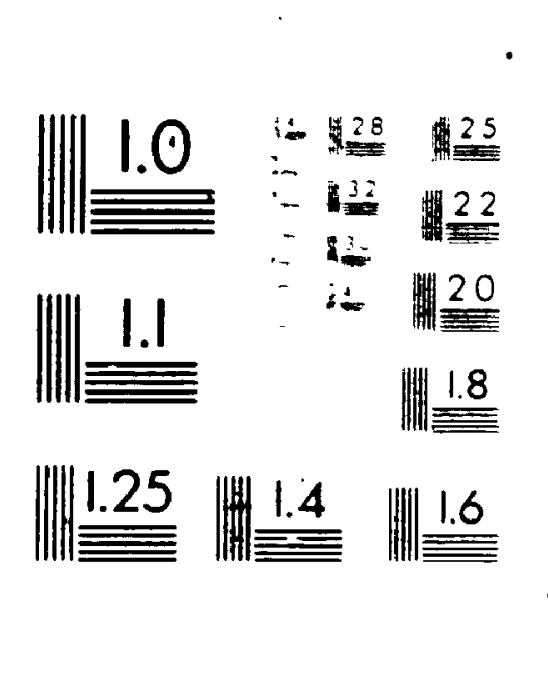





\section{APRENDIX_A: LITERATURE REVIFW CODING}

\section{CRITICISHS and PRESCRIPIIONS}

\section{CODING .}

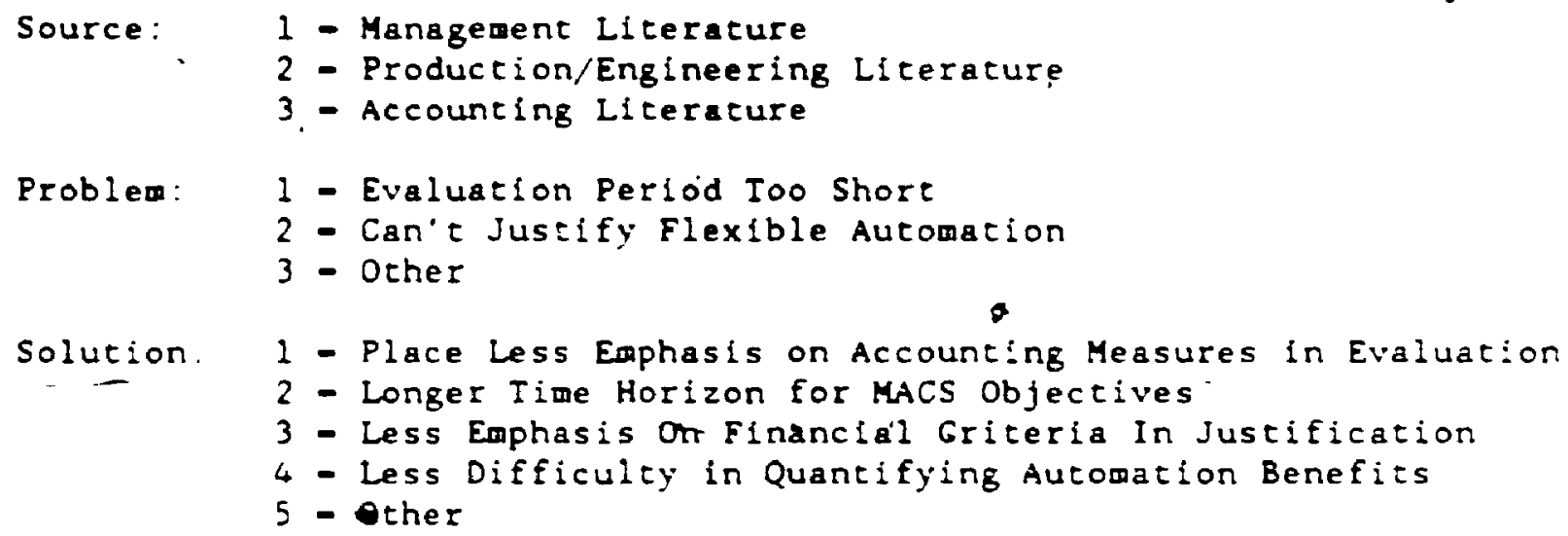

\begin{tabular}{|c|c|c|}
\hline AUTHOR (S) & TITLE & CODING \\
\hline $\begin{array}{l}\text { Alvonfics } \\
\text { Parkinson } \\
(1986)\end{array}$ & $\begin{array}{l}\text { The Adoption of Flexible } \\
\text { Manufacturing Systems In } \\
\text { British and German Companies }\end{array}$ & 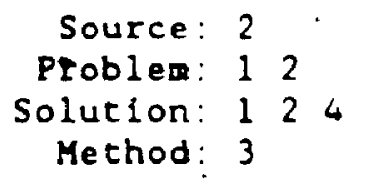 \\
\hline $\begin{array}{l}\text { Ayres \& Miller } \\
(1983) \\
\end{array}$ & $\begin{array}{c}\text { Robotics: Applications and } \\
\text { Social Implications } \\
\text { - }\end{array}$ & $\begin{aligned} & \text { Source: } 2- \\
& \text { Problem: } 1 \\
& \text { Solution: } 25 \\
& \text { Method: } 3\end{aligned}$ \\
\hline $\begin{array}{l}\text { Banks } \\
\text { Whee Iwright } \\
(1979)\end{array}$ & $\begin{array}{l}\text { Operations us Strategy: } \\
\text { Trading Tomorrow for Today } \\
\end{array}$ & $\begin{aligned} \text { Source: } & 1 \\
\text { Problem: } & 1 \\
\text { Solution: } & 12 \\
\text { Method: } & 3\end{aligned}$ \\
\hline Barrie (1986) & A Fresh Look at Accounting & $\begin{aligned} & \text { Source: } 2 \\
& \text { Problem: } 2 \\
& \text { Soluclon: } 34 \\
& \text { Method: } 1\end{aligned}$ \\
\hline Bernard $(1986)$ & $\begin{array}{l}\text { Structured Project Methodology } \\
\text { Provides Support for Informed } \\
\text { Business Decisfons }\end{array}$ & $\begin{aligned} \text { Source: } & 2 \\
\text { Problem: } & 2 \\
\text { Soluclon: } & 5 \\
\text { Hechod: } & 1\end{aligned}$ \\
\hline
\end{tabular}




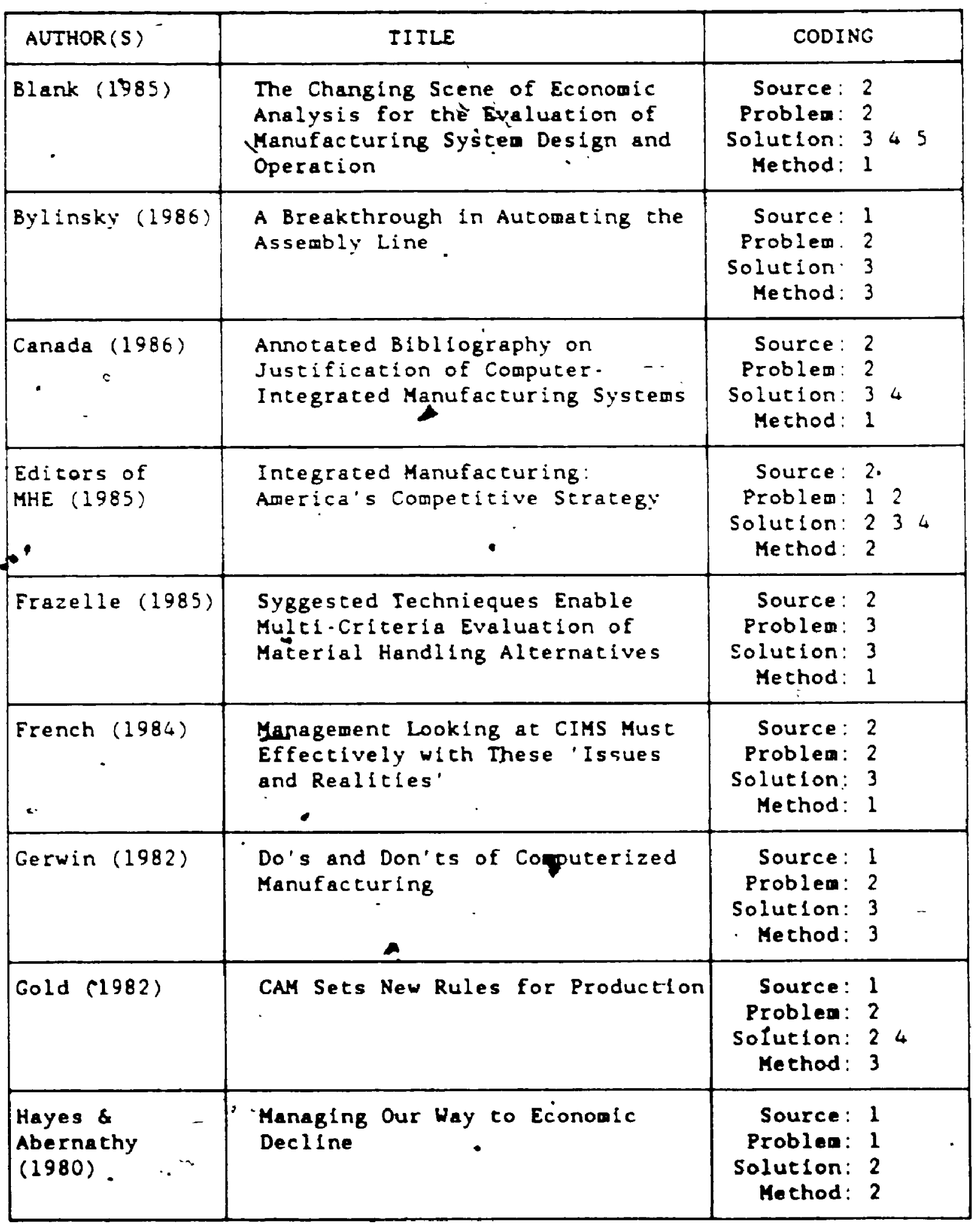




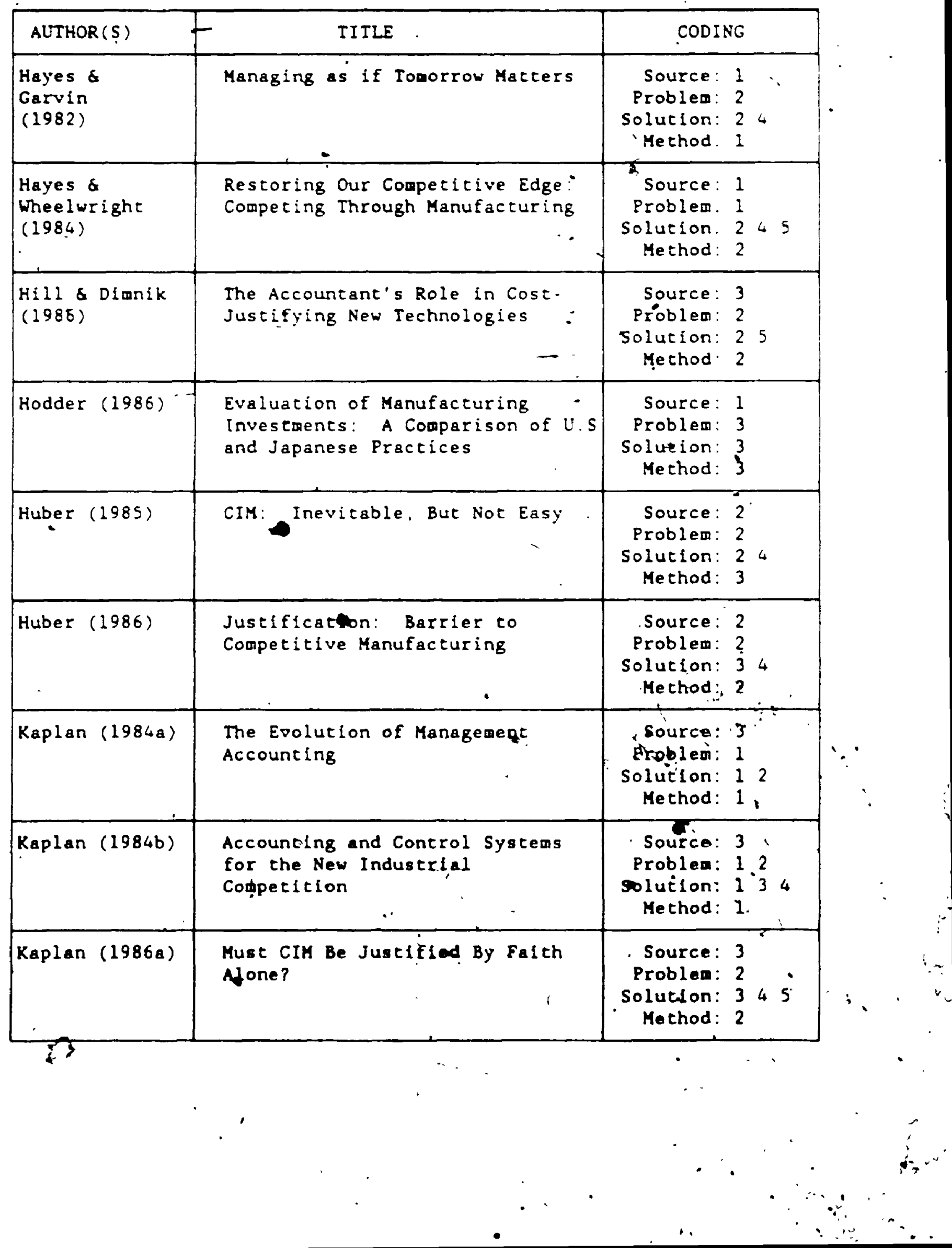




\begin{tabular}{|c|c|c|}
\hline AUTHOR (S) & IITLE & CODING \\
\hline McDonald (1985) & $\begin{array}{l}\text { Modern Systems Denand Fresh Look } \\
\text { at ROI Concepts }\end{array}$ & $\begin{aligned} \text { Source: } & 3 \\
\text { Problem: } & 2 \\
\text { Solution: } & 4 \\
\text { Method: } & 2\end{aligned}$ \\
\hline McLean (1986) & $\begin{array}{l}\text { Manufacturing: Competitive Edge } \\
\text { or Corporate Millstone } \\
\text {. }\end{array}$ & $\begin{aligned} \text { Source: } & 3 \\
\text { Problem: } & 1 \cdot 2 \\
\text { Solution: } & 2 \\
\text { Fethod: } & 1\end{aligned}$ \\
\hline $\begin{array}{l}\text { Merchant \& } \\
\text { Bruns } \\
(1986)\end{array}$ & $\begin{array}{l}\text { Measurements to Cure } \\
\text { Management Myopia }\end{array}$ & $\begin{aligned} \text { Soùce : } & 3 \\
\text { Problem: } & 13 \\
\text { Solution: } & 5 \\
\text { Method: } & 1\end{aligned}$ \\
\hline Pearson $(1986)$ & $\begin{array}{l}\text { The Strategic Discount } . \\
\text { Protecting New Business Projects } \\
\text { Against DCF }\end{array}$ & 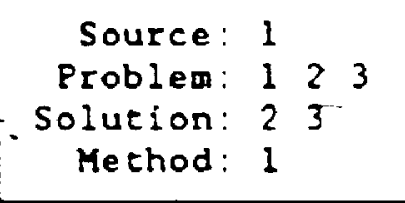 \\
\hline Port $(1087)$ & Making Brawn Work with Brains & $\begin{array}{r}\text { Source: } 1 \\
\text { Problem: } 2 \\
\text { Solution: } 4 \\
\text { Method: } 2\end{array}$ \\
\hline Powel1 (1986) & $\begin{array}{l}\text { Turning Costing On Its head } \\
\text {. }\end{array}$ & $\begin{aligned} & \text { Source: } 2 \\
& \text { Problem: } 2 \\
& \text { Solution: } 4 \\
& \text { Method: } 2\end{aligned}$ \\
\hline $\begin{array}{l}\text { Primrose, } \\
\text { Bailey } \\
\text { Leonard } \\
(1984)\end{array}$ & $\begin{array}{l}\text { The Practical Application of } \\
\text { Discounced Cash Flow to Plant } \\
\text { Purchases Using an Integrated } \\
\text { Sulte of Computer Progran }\end{array}$ & $\begin{array}{r}\text { Source: :- } 3 \\
\text { Problem: } 2 \\
\text { Solution: } 45 \\
\text { Method: } 1\end{array}$ \\
\hline$R 1 z 21$ (1984) & $\begin{array}{l}\text { Capital Budgeting: Linking } \\
\text { Firiancial Analysis to Corporate } \\
\text { Strategy } \\
.\end{array}$ & $\begin{aligned} & \text { Source: } 1 \\
& \text { Problem: } 2 \\
& \text { Solution: } 4.5 \\
& \text { Method: } 1 \\
&\end{aligned}$ \\
\hline $\begin{array}{c}\text { Sheridan (1986) } \\
\therefore\end{array}$ & How to Account for Manufacturing & 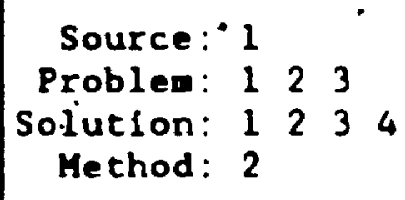 \\
\hline
\end{tabular}


187

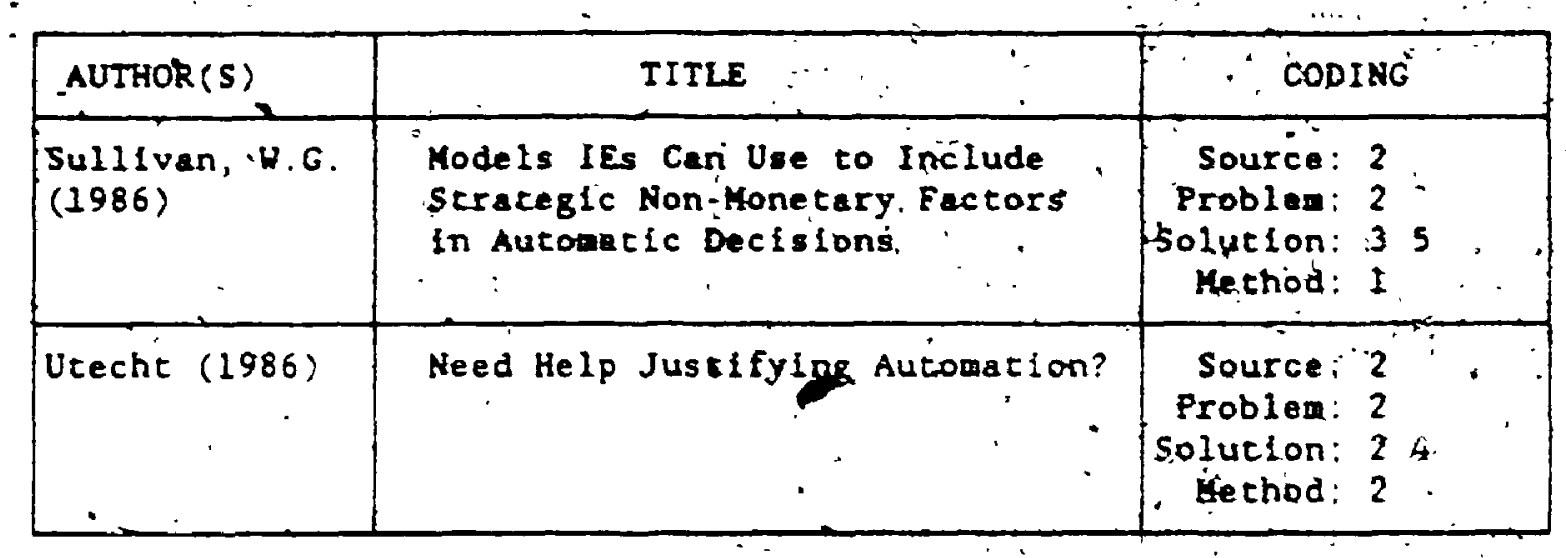



DOCTORAL PROGRAM RESEARCH

Scthool of Busines Admuncstration

London, Conede

N6A 3K7

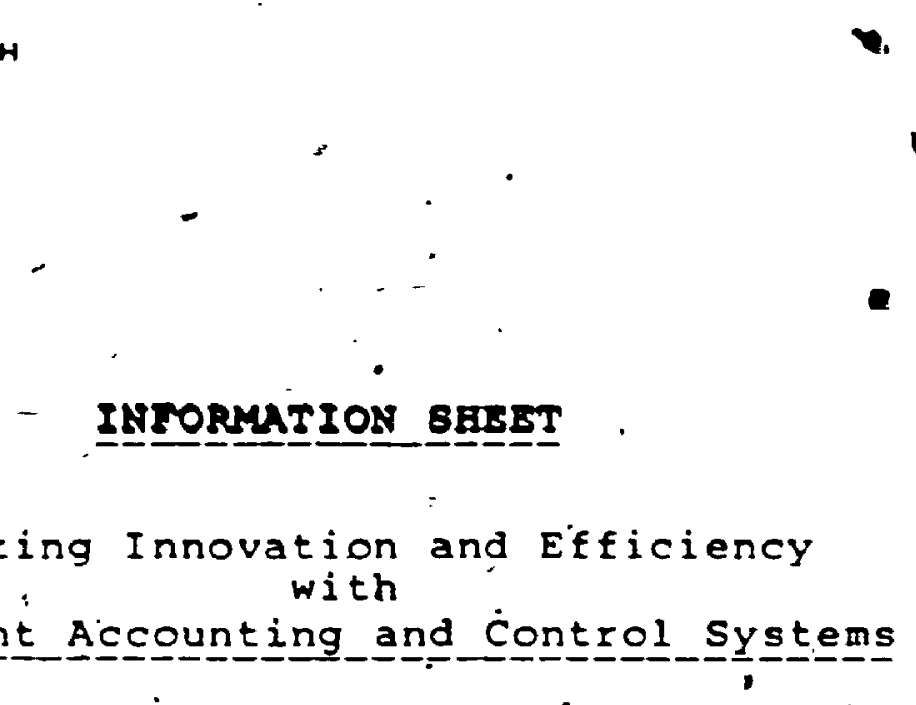

The study focuses on four groups of suppliers to General Motors of Canada:

1. Large/Medium Metal stampeìs

2. Thermoplastic Injection Molders

3. Rubber Parts Manufacturers

4. Functional and Decorative Die Casters

We have chosen 6 representative plants from each group for a total of 24 plants.

The managers of these 24 plants will receive questionnaires which should take less than one hour to complete. Mr. Dimnik will visit the plants to pick up the questioninaires and to conduct interviews with the plant managers. Interviews should take less than 90 minutes.

Data from the questionnaires and interviews will be summarized and interpreted in a report which will be sent to General Motors and to all participating suppliers.

'The data will'also be used'in a PKD thesis and in articles in academic and management journals."

The information from each plant manager will be held in the strictest confidence. No information that could identify any individual plant or manager will. be released to anyone, including General Motors. Results will be reported only as statistlcal aggregations. 
$\because$.

\section{RESPONSE SHEET}

We need the name of the plant or manufacturing wanager for PLANT NAME The person selected for the study should weet the following criterta:

1. The person should be someone who makes capital budget proposals to top managent but does not have authorlty to approve them.

2. The person should té responsible for the operation of the plant. Please print the name, telephone nü̈ber and address of the plant or manufacturing manager who will particlpate in the study:

NAME:

TI TLE :

: PHONE NUMBER:

MAIL ADDRESS :

Kr. DImnlk vill contact the person named above.

Please print your name and title:

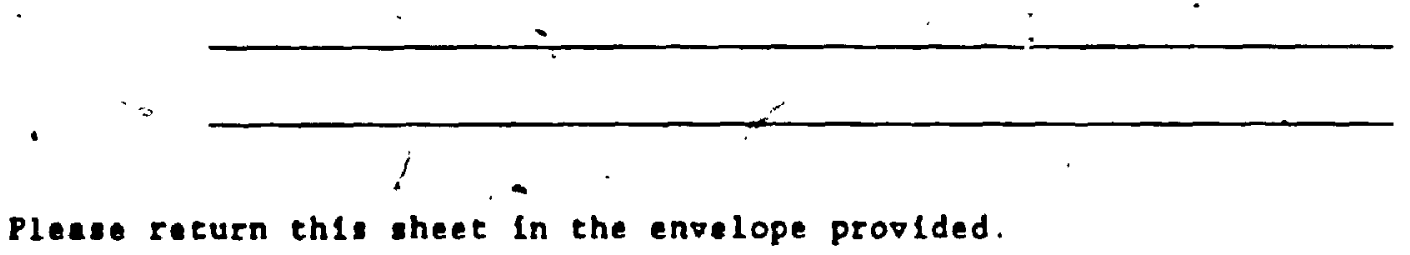

Thank you. 



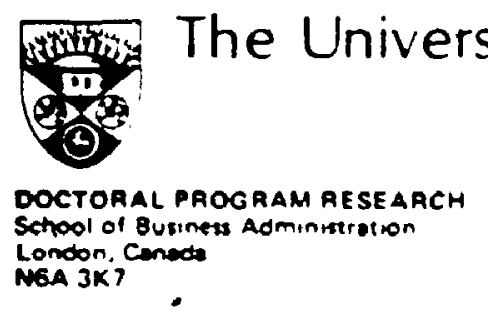

\section{sity of Western Ontario.}

DATE

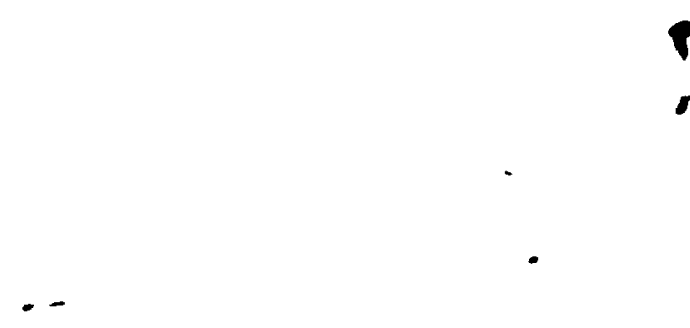

NAME

TITLE

COMPANI NAME

ADDRESS

ADDRESS

POSIAL CODE

Dear

You are one of a small group of managers that has been selected for a study of efficlency and Innovation in the automotive industry. CEO NAME suggested your name to us.

Plant managers of current and potential suppliers of parts to General Motors of Canada have been sent coples of the e:closed questlonnalre. The questionnal.re wlll be followed up by personal interviews.

Because only a small sample of managers has been selacted. formeth study, It is important that you complete the questionnalre and return it in the envelope provided.

in on that could Identfy any company or any manager will be released to anyone, Including General Motors. Results will be reported only as statistlcal aggregations.

When the project is completed you will recelve a copy of the report sent to General Motors. I wll also glve you complete explanation of the research when we weet in the next few weeks.

I would be most happy to answer any of your questlons. My telephone number is (613) $545-2315$.

Yours truly.

Tony Dimik.

Doctoral Candidate 


\section{Instructions}

This questionnaire should take lesf than one hour to complete. Most of the questions can be answegof simply by circling a number.

If you don't understand a question or can't answer it, please leave it blank and put a question mark (?) in the margin.

Questionnaire responses will be followed up with personal interviews later in september.

Data from the questionnaires and interviews. will be summarized and interpreted in a report which will be sent to General Motors and to all survey participants. The data will also be used in a PhD thesis and in articles in academic and management journals.

The infarmation you give the wili be held in the strictest confidence.

Each questionnaire has an ldentification number for mailing purposes only. This is so that I may check your name off my Iist when your questionnaire is returned. Your name will never be praced on the questionnaire itself.

No information that could identify you or your company will be released to anyone, including General Motors. Results will be reported only as statistical aggregations.

Please complete and return the questionnaire as soon as possible. 


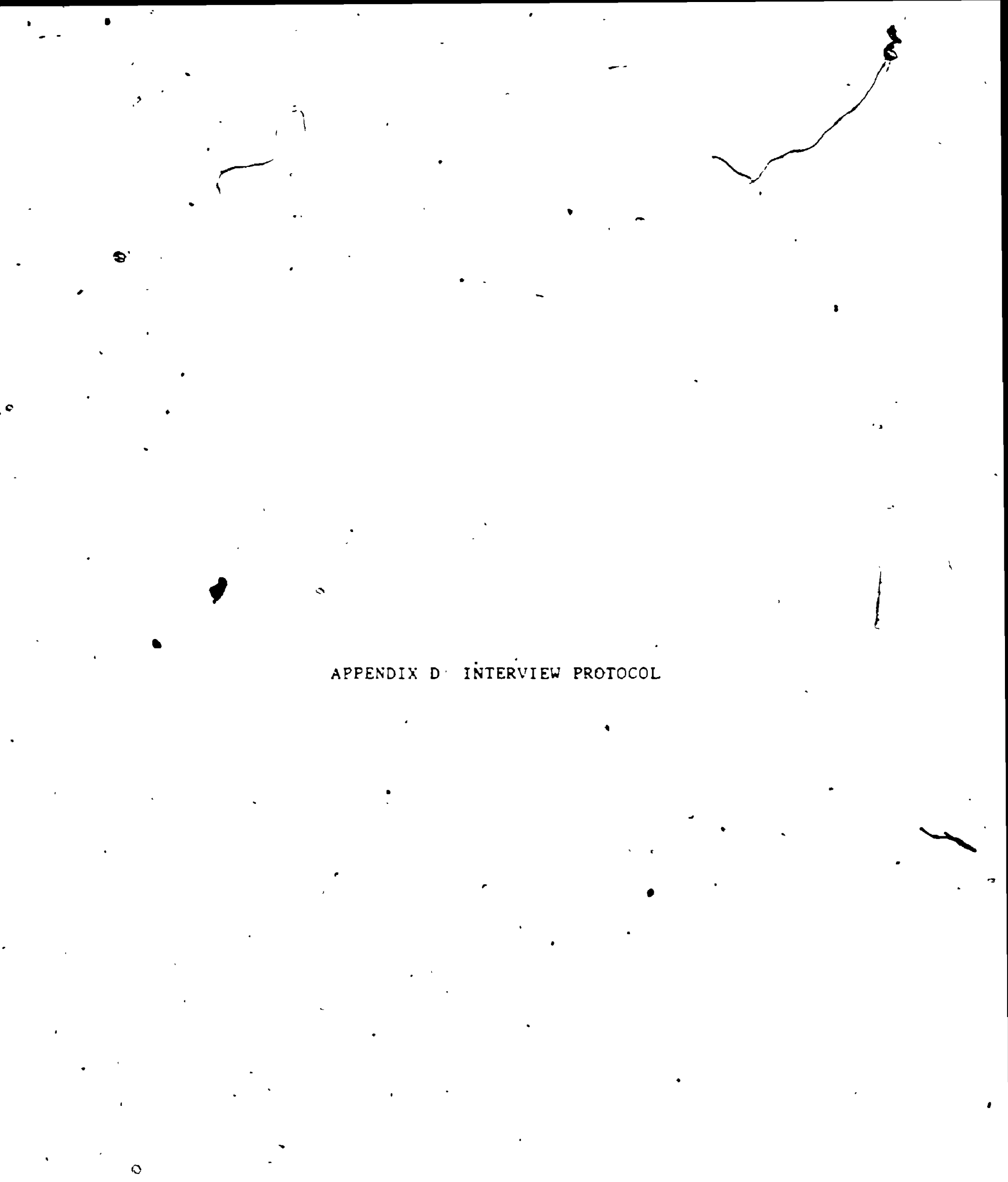


This interview will have two parts. First I will ask you some questions and then I'll explain what we' re hoping to accomplish with this study.

As I stressed in my earlier correspondence, anything you say to me will be held in the strictest confidence. No one will be able to identify you or your company

I would like to tape-record our session I will be the only person to isten to the tape I find tapes helpful in making sure I have the correct information, but I won't use. the recorder unless you feel comfortable with it May I use the recorder?

- Do you have-any questions befote we start? 
I'll begin by asking you some questions about the flexible automation technologles you use in your plant.

[FOR EACH OF THE FOLLOWING ASK:]

Does your plant have....

How is the technology used?

How long has the technology been in place? -

Has it been successful?

Induserial Roboes

Programable Conerollers

Numerically contro: led machines (NC)

Computer controlled NC

machines (CNC)

Computerized material.

handling equipment.

Computer-aided inspection

and testing devices

Computer-alded design (CAD).

Incegration between $C A D$ and computer-alded manufacturing (CAD/CAM). 
Do you think your plant could use more flexible autoration?

IIF SAY YES. PROBE] What's holding you back?

- top management

- accounting system

- other reasons

Are you ever frustrated when you want to buy some hew machinery or equipment and can't get approval?

I would like to talk about your latest purchase of flexible autonation What is the newest flexible automation equipment in your plant?

When was it purchased?

Whose idea was it to get it?

Did the equipant purchase have to go through a formal approval process? Describe that process... [PROBE]

- did anyone have to do a formal financial analysis

- role of accountants in process (any conflict)

- plant manager's role in process

- cop management role in process (top down/botcom up)

Was this purchase of machinery typical? How does it differ from norms? 
Ate capital invescments in your plant required to exceed a certain rate of return or hurdle rate?

What is the hurdle rate?

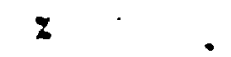

How important is hurdle rate in getting approval to buy new equipment?

Are some capital investments in flexible automation required to meet a different hurdle rate than other investments?

What is the hurdle rare for flexible automation?

Has the hurdle rate changed in the past few years?

Does it change with inflation rate?

Is there a required payback period for capital investments in your plant?

What is the required payback? years

Are some capital investments in flexible autonation required to meet a different payback perlod than other investments?

What is the payback period for flexible automation?

years

Has the payback perlod changed in the past few years?

Does it change with Inflation rate? 


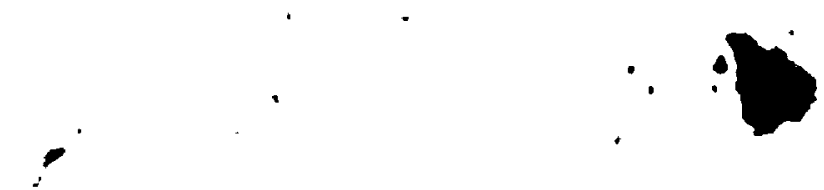

TAND OVER 'CARD AND ASK .TO COMPLETE WHILE EXPLAINING CHOICES ;

Please explain cholces as you go along...

What do you think equnts the mosi in how your boss evaluates your performance?

Put the number 1 aext to the item you think colints the most

Put the number 2 next to the item that counts second post.

Put the number 3 next to the 1 tem that counts third most

Finaliy, put the number 4 rext to the item that counts fourth wost

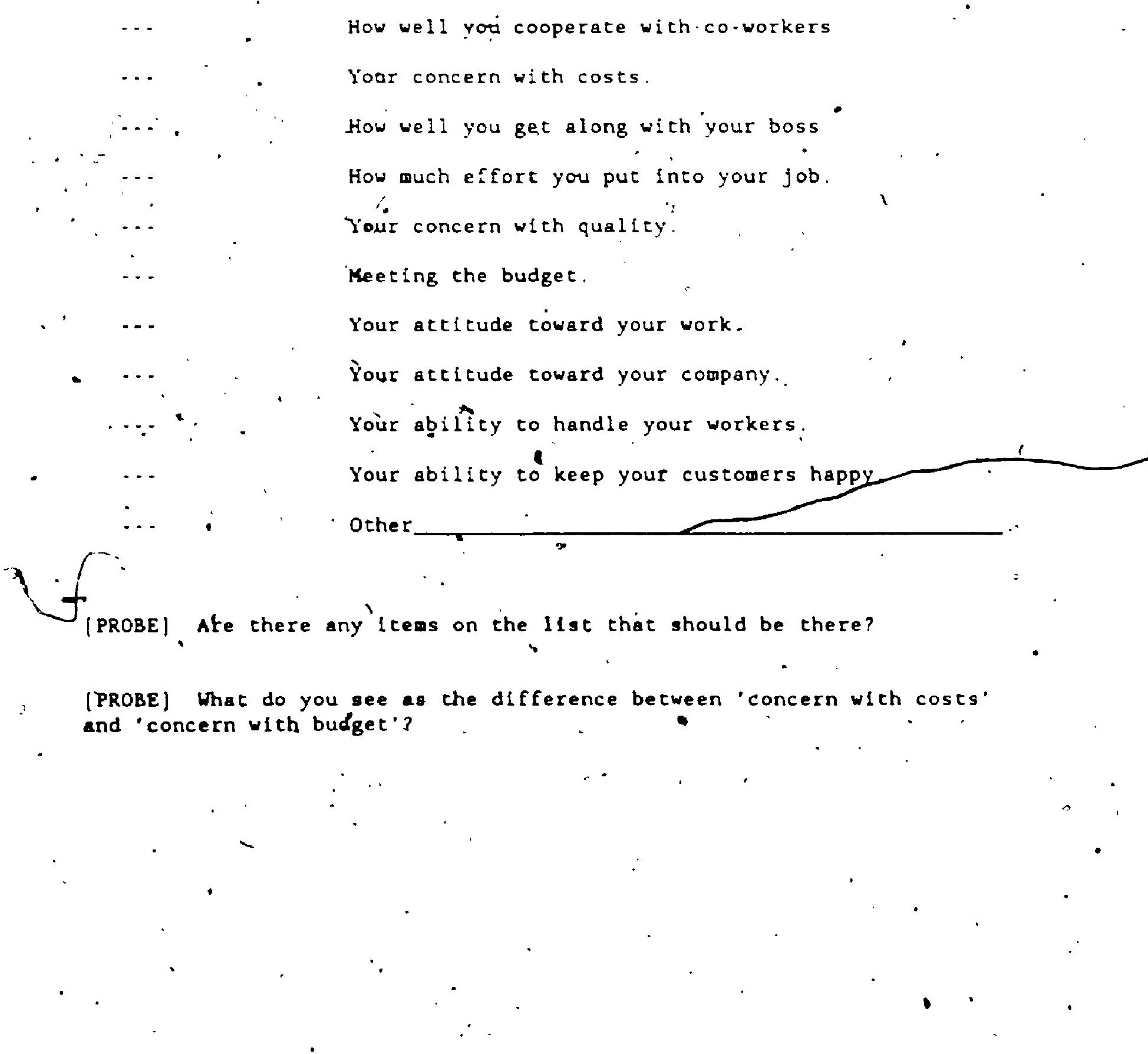


In the last question we talked about your boss... who is your boss?

Nane

Title

How long has your boss beèn in his job?

years

- -

Any changes in the way you are evaluated in past few years?

[PROBE IF EVALUATION CHANGE WITH CAANGE IN BOSS]

Let's talk a bit about your job... How do you defiñé your, job?

[PROBE DUTIES, AUTHORITY, PROFIT/COST/INIESTMENT CENTER?]

How far ahead do you plan?

What sort of information. do you keep track of so that you know what's going on in your plent?

Dó you keep your own personal records to make sure everything's going . we 11? - $[$ PROBE]

what Information

what form (pencil/paper, computergetc.)

How Important is accouting Information for you?

- for evaluating your workers

- For naking declsions

- to know what' going on

Are you satglafid with the financlal information you' re getoing?

Are you gatisfled with the way the financial information is being used by your superlors, by co-workers? 
Please give me a description of your manufacturing process' [PROBE: TYPE OF PROCESS BATCH SIZE INVENTORY LEVELS

TYPE OF MATERIAL USED

TYPE OF LABOR USED (SKILLED OR UNSKILLED)

Can you give me a rough jợea of your costs.. For your major products. what percent of your total costs are:

- in ow materials

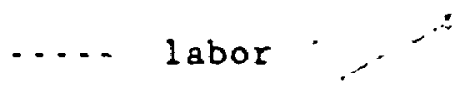

.... overhead

What are the key. success factors for your plant? What do you have to do well to be successful?

202 

ID - GROUP - PLANT

number of robots

earliest date of adoption in anths (October-0)

robnum

success.of robot applications (1-none 2-some 3-lots 9-unknown) robtim robsuc

number of programmable controllers

earliest date of adoption in months (October-0).

success of PC applications (1-none 2-some 3-lots,9-unknown) consuc

number of CNC machines

cnenum

earliest dace of adoption in months (October-0)

cnction

success of CNC-applications (1-none 2-some 3-lots 9-unknown)

use of computerized material handling (none-0 some-l)

earliest date of adoption in months (October-0)

natuse mateim

success of material handilng (1-none 2-some 3-lots 9-unknown) matsue

use of computerized inspection (none-0 some-1)

earliest date of adoption in months (October-0)

success of comp inspection (1-none 2-some 3-lots 9-unknown)

Insuse

instion inssue

use of CAD (none-0 outside-1 head-office-2 onsite-3) earllest date of adoption in months (October-0) success of CAD (1-none 2-some 3-lots 9-unknown)

caduse cadtim cadsuc

integrated computerlzed manufacturing (none-0 some-1)

earliest date of adoption in nonchs (October-0)

camuse

success of CAM (1-none 2-some 3-lots 9-unknown)

could use more FA. (0-no 1-lukewarm 3-positive 5-enthuslastic) morefa

frustrated in p'roposals (0-no 1-sode 2-yes)

frustr

payback on FA (In months)

TMHOR $3 F$

paybick Important (no-0 some-1 very-2)

EMFJST2F 
*.

budget constrained -4

budget/profit-3

profit-2

non-account ing-4

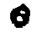

respondent level (1-low 2-tiddle 3-upper)

MANPOS 1

responsible for sales (1-no 2-some 3-yes)

MANPOS2

Job Definftion

satisfied with financial info (0-no l-quite 2-very)

satfin

raw materials ( $x$ of fotal costs) *

matcos

labor ( $x$ of total costs)

labcos

overhead ( $x$ of cocat costs)

ovrcos

Key' Success Factors

visited/not-visited plant (0-nó l-yes) vispla

[FROM PLANT TOUR]. 


\section{BIBLIOGRAPHI}

"Cost Accounting For The '90's", Management Accounting, (Jesly 1986), volume 68, Number 1, pp. 58.59

Abernathy.. W.J., The Productlvity Dilema. (1978), Baltimore, Maryland The John Hopkins University Press.

Arbose, J.. "Manufacturing: management's neu competitive weapon". International Management, (February 1985), Volume 40, Number 2. PP. $20-26$.

Armitage, H.M. and Skelton, W.J., "Accounting Systems And The Limits Io Quality Management Decision Making". Business Quarterby, (March 1987), Volume 51, Number 4, Pp. 52-56.

Arnholt, M., "People, Not Machines, Are The Answer". Ward's Auto World. (June 1986), Volume 22, Number 6, pp. $38-39$

Ashburn, A., "Cost Accounuing At The Crossroads", American Machinist Autonated Manufacturing. (May 1986), Volume 130, p. S.

Atkinson, A. and Cummings, G.. "Testing Kaplan's Theories", CMA Kagazine. (July-Auguse 1986), Volume 60, Number 4, pp. $37-43$.

Automotive Industry Human Resources Task Force, Report of the Automot lve Industries Human Resource Task Force. (1986). Minister of Supply and Services Canada.

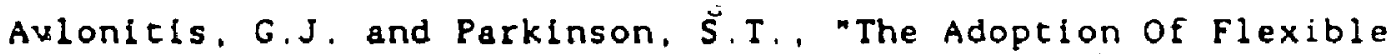
Manufacturing Systexis In British And German Companies", Induscrial Marketlog Management, (May 1986), Volume 15, Number 2, PP. 97108.

Ayres, R,U, and Miller, S.M. Reberics: Apolications And Sochal Impl fcatiens, (1983), Cambridge, Massachusetts: Ballinger Publishing.

B-0-C Document, Supolfer Assessment and Expectatiens fer Supolters. (August 1, 1986). Internal General Motors Document.

Banks, R.L. and wheelwright, S.C., -Operatlons Vs. Strategy: Trading Tomorrow For Today", Harvard Business Revlew, "(May-June 1979). Volane 57, Number 3, pp. 112-120.

Barrie, E.. "A Fresh Look At Accounting", EAD/CAY\& RobotfGs. (February 1986), Volume 4, Number 1, p. 6. 
Bernard, P.. "Structured Project Methodology Provides Süport For Inforaed Business Decisfons". Induscrial Englneerini, (March 1986), Volume 18, Number 3, Pp. 52.57.

Bessant, J.R., "Influential Factors In Hanufacturing Innovation": Besearch Polfey, (1982), Volume 11, pp. 11)-132 -

Blank, L., The Changing Scene of Economic Analysis for The Evaluation of Manufacturing System Design And Operation". The Engineerito Economist. (Spring 1985), Votume 30, Number 3, pp. 227-244

Bolz, R.H. Manufacturlne Automatien Manazemenc, (1985), New York: Chapmen and Hill.

Bower, J.L., Managine The Resource Albecation Process, (1970). Boston: Division of Research, Harvard University Graduate School of Business.

Brealey, R. Meyers, S., Sick, G. and Whaley, R., Rrinciples of corporate Finance, (1986), Toronto. McGraw-Hill Ryerson Limited.

Brownel1, P.. "The Role of Accounting Data In Performance Evaluation. Budgetary Particlpation, And Organizational Effectiveness".

Journal of Accounting Research. (Spring 1982). Volume 20. Number 1. pp. $12 \cdot 27$.

Browne 11, P. and Hirst, M. "Rellance On Accounting. Information. Budgetary Participation. And Task Uncertainty: Tests of A Three. Way Interaction". Jeurnal of Accounthe Research. (Autumn 1986). Volume 24, Number 2, Pp. 241-249.

Bruns Jr., W.J. and Waterhouse, J.H., "Büdgetary Control And Organization Structure". Jeurnal of Accounting Research. (Autumn 1975), Volume 13. Pp. $177-203$.

Bylinsky. G., "A Breakthrough In Automating The Assembly Line". Eertune, (May 26:, 1986), Volume 113, Number 11,- PP. 64-66.

Canada, J.R., "Annotated Blbliography-om-rustlfication of ComputerIntegraced Manufacturing Systems'. The Engineertag Economist. (HInter 1986), Volume 31. Number 2, Pp. 137-150.

Canadian CAD/CAM Council for the Advancement of Computer Integrated Manufacturing. CAD/CAM Rewsletcer, (February 1987).

Canadian Manufacturers' Association, Competing Ih The Global Village, (September 1982).

Carruth, P.J. and McClendon, T.O." How Supervlsors React To 'Meeting The Budget' Pressure", Manszement Accounclng, (November 1984). Volume IXVI, Number 5, PP. 50-54. 
Caves R.E., Industrial Organization, Corporate Strategy And Structure". Journel of Econenic Literscure, (March 1980), volume XVIII. PP. $64=92$.

Chalos, P. and Badger, A.H.. "High-Iech Production: The Impact on Cost Reporting Systems". Jeurnal of Accouncancy, (March 1986), Volume 161, Number 33. pp. 106-112.

Cherihall. R.H. and Morris, D., The Impact of Structure, Environment, And Incerdependence On The Perceived Usefulness of Management Accounting Systems". The Accountine Revlew. (January 1986). Volume LXI. Number 1, PP. $16 \cdot 35$.

Child, J., "Strategles of control and organizational behavior". Administrative Science Quarterly.. (1973), volume 18, PP. $1-17$.

Cohen, J.. Statistical Power Analys is For The Behavioral Sciences (Revised Edition), (1977). New York: Acodemic Press.

Cohn, S.F, and Turyn, R.M., "The Structure of the Firm and the Adoption of Process Innovations". IEEE Trensactions On Englneering Manasement, (November 1980), Volume EM-27, Number 4, PP. 98-102.

Cohn, S.F. and Turyn, R.M., "Organlational structure, Decision-Making Procedures. And The Adoption of Innovations". IEEE Transactions Oh Engineering Manezenent. (November 1984), Volume EM-31, Number 4. PP. $154 \cdot 161$.

Cook, R.L., "Assessing The Adoption of Robotics Technology", Unpubitshed Dissertation. (1986), Duke University.

Courtis, K.S., "The North American Automotive Producers and Supply Sourcing in Japan", Unpublished Paper. (December 8; "1986). Laval University.

Dermer, J., The Interrelationship of Intrinslc And Extrinsic Motivation". Academy of Manazement Journal, (March 1975), Volume 18. Number 1, PP. $125 \cdot 129$.

Dewar, R.D., whetcen, D.A. and Bofe, D.. "An Examination of The Reliability And Valldity of The Alken And Hage Scales of Centralization, Formalization, And Task toutiness": Adminlescative Sclence Quarcerly. (March 1980), Voluae 25, Pp. $120-128$.

DIIts. D.M. and Russell, G.W. -Accounting For The Factory of The Futuge". Hanagement Accounting. (Apr11 1985)., PP. 34-40.

Dinn, J., "Materlal Handl Ing Systeas". Secend Annuat Internactencl" Seminar on Flexible autemacien assembly. (1985). Toronto. Canade 
Economic Counc11 of Canada. Making Technelezy Work: Innevatien dnd Jobs In Canada, (1987). Jexinister of Supply and Services Canada.

Editors of MHE, "The Autonated Factory: Opinions And Insights". Katerifl Handling Englneerlog, (May 1985), Volume 40, Number 5. Pp. $78-80$.

Flynn, M.S., "Out-sourcing rediscovered", IEEE Spectrum, (October 1987), Volume 24, Number 10, Pp. 47.49.

Fornell, C., A. Second Generation of Mulcivariace Analysis: Classification of Methods and Implications for Marketing Research". Herkine Paper. (1984), Graduate School of Business Administration. University of Michigan.

Frazelle, E., -Suggested Techniques Enable Multi-Criteria Evaluation Of Material Handling Alternatives". Industrial Engineerfog. (February 1985), Volume 17, Number 2, pp. 42.48.

French, R.L., Management Looking At CIMS Must Deal Effectively with These 'Issues And Reallties" "Industrial Encineering, (August 1984). Volume 16, Number 8, PP. 70.77 .

General Motors of Canada, Rroceedings of the General Moiers of Canada supolier Council Qualify Seminar. (1986).

Gerwin. D.. "Control And Evaluation In The Innovation Process: The Case of Flexible Manufacturing Systems". IEEE Transacelens on Engineerfok Manaqement, (August 1981), Volume EM-28, Number 3, pp. $62-70$.

Gerwin, D., "Do's and Don'ts of Computerlzed Manufacturing". Harvard Buglness Review, (March-Apr11 1982). Volume 60, Number 2, pp. $107-116$.

Gold, Bela, "CAM Sets New Rules For Production" Harvard Busthess Revlew, (November-December 1982), Volume 60 , Number 6, PP. 88-94

Govindarajan, V., "A Contingency Approach to Strategy Inplementation at, the Business Unit Leved: Integrating Adninistiat Ive Mechanisms with Strategy", Horkin Amper, (October 1987), The Amos Tuck School of Business Administration. Dartmouth College.

Greenwald, J., "Lulu Is Home Now: GM buys Hughes and heads for the 2f st century", Ifme. (June 17, 1985), PP. S0-53. $\because$

Hackan, J.R. and Porter, L.W., "Expectancy Theory Predictions of Work Effectlveness"; - Organhzathal Behavlour And Human Performance, (1968), Volune 3, PP. 417-426. 
Hage, J. and Aiken, M., Prográ Change And Organizacional Propertes A Comparative Analysis". The Amerlean Jeurnal of Soclelery. (March 1967). Volume 72. Number 5, PP 453.519.

Hage, J. and Afken, M. "Rout Ine Technology, Soclal Structure, And Organizational Goals". Admbiscraclve sclence Quarcerb. (September 2969). Volume 14:. Number 3. pp. 366.376

Haka, S.F. - Capital Budgeting Techniques and Firw Speciflc Contingencies A Correlational Analysis". Accounting.

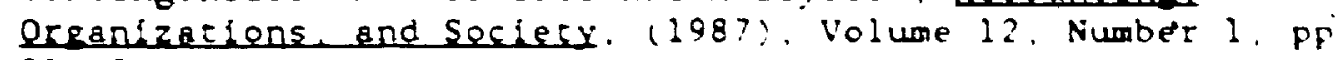
$31 \cdot 48$

Hayes, D C... "The Contingency Theory of Managerial Accounting". . The Accountine Revies. (January 19?). Volume LII. Number 1 PP $22-39$

Hayes. $R H$ and Abernachy, $b J$. Managing Our tiay Io Economir Decline". Harvard Business Bevew. (Julvaugust la8c), Volume ": Number 4, PP 67.7?

Hayes, R.H, and Garvin. "D A, Managing As If Tomorrow Mateered". Harvard Business Review, (March-Apr!l 198?). Volume b0. Numher? PP. $70-78$.

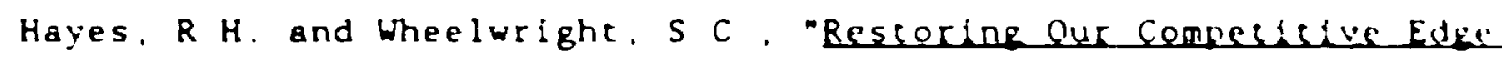
compecine through Manufaceurige. (1984). New York John wiley o Sons. $\therefore$

Hill, N., "Controls at the Departmental Level An Exploratory Study". Unoublished Dissertation. (1984). Jork University (T6anto:

- Hill, $N$ and Dlmnik, $T$. "The Accountant's Role In Cost Just Ifing Nivw Technologies". CMA. (November-December 1986), Volume 60. Niuntiei t. pp. $31 \cdot 37$.

Hodder, J.E. Evaluation of Manufacturing Investoents A Comparison Of U.S. And Japanese Pracilces". Elnancial Management. (Sprlng 1486). Volume 15. Number 1. PP. 17.24

Hofstede, G.H. . The Game of Budzet centrel. (1968). London. England Tavistock. Publications Liolited

Hopwood. A.G. "An Enplelcal Study of The Role of Accounting Daen In Performance Evaluation". Leurad of Acceunchne Resench (Emolelcal. Resench in Acceunslop Selecked studtes). (1972). Volume 10. PP. $156 \cdot 182$

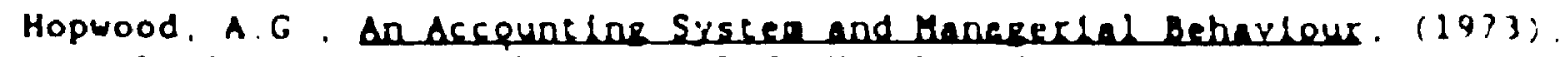
Lexington. Massachusetcs $D C$ Heach and Company 
Huber, R.F., "Justification: Barrier To Competitive Manufacturing", Productien. (September 1985), Volune 96; Number 3, PP. $46-51$.

Huber, R.F.. "CIM: Inevitable, But Not Easy", Rroduction. (April 1986), Volume 92:, Number 4, PP. \$2-56.

Ifiri, Y., The Foundaciens of Accouncine Hessurenent, (1967), Englewood Clifss. New Jersey: Prencice-Hall.

IMEDE, Rerspective for managers, (1987), Number 6.

Inkson, J.H.K., Pugh, D:S. and Hickson, D.J., Organization Context And Structure: An Abbreviated Replication". Administrative Science Quarterly, (September 1970), Volume 15, Number 3, Pp. 318.329

Itami, H. Adaptive Behaviour: Management Control And foformation Anabisis. (1977), Sarasota, Florida: American Accounting Association

Jaikumar, R., "Flexible Manufacturing Systems A Managerial Perspective". Workine Paper 1-784-078, (January 1984), Harvard

3 Business School.

Jelinek, M. and Goldhar, J.D., "The Interface Between Strategy And Manufacturing Technology", Columbia Journal of Worle Business. (Spring 1983), Volume 18, Pp. 26-36.

Jelinek'M, and Goldhar, J,D., "The Strategic Implications of The Eactory of The Fucure Slean Manazement Review, (Sumer 1984), Volume 25, Number 4, pp. 29-37.

Jones, D.I., "The Internationalization of The Automobile Industry". Journal of General Hanazement, (Spring 1985), Volume 10, Number 3. PP. $23.44 .4^{\circ}$

Kantrow, Alan M. (Edicor), Suhival Strateries Fer American Industri, (1983), New York: John Wlley Sons.

Kaplan, R.S.. Measuring Manufacturing Performance: A New Challenge For Hanagerial Accounting Rasearch". The Accounting Review, (October 2983), Volume LVIII, Number 4, ppe 686.705.

Kaplan, R.S., "The Evolution Of Management Accounting". The Accounting Review, (July 19848), Volume LIX, Number 3, PP. $390-418$.

Kaplan, R.S., "Accounting And Control Systems For The New Industrial Competition", Werkine Paper 9-784-054, (1984b). Harvard School of Business. 
Kaplan, R.S., Quantitative Models For Managedent Accounting In Today's Production Environent (Revised)". Eourth Annual Deleitte. Haskins and Sells Accouncline Research Sympesfun, (January 1985). London Business School.

Kaplan, R.S., "Must CIM Be Justified By Falth Alone", Hariard Bustress Revier. (July 1986a). Volume LIX, Number 3. PP 390.418

Kaplan. R.S., "Accounting Lag: The Obsolescence of Cost Accounting Systems". Celifornig Manazement Reviet. (Winter 1986b). Volume is Number 2. PP 174.199.

Kaplan. R.S... The Role For Empirlcal Research In Manageaent Accounting". Accounclne Qreanizacions And Secless. (1986c) Vol 1 me 11. Number 4/5. PP 429.45?

Kerlingër, F.N . Foundacions of Behavioral Research CSecond Edicioli. (1973). New lork Holt. Rinehart and finston

Kester. CH., "Today's Options for Tomorrow's Growth", Harvard Businese Review. (March-April 1984). Volume 62. Number? PP 153.160"

Kidder, L.H . Besearch Methods in Seclad Belations CEeurth Edicion: (1981), New York Holt. Rinehart and winston

$5 \quad$ Kim, S.H... "An Emplrical Study On The Relationship Between Capital Budgeting Practices And Earnings Performance". The Eneinescher Economist. (1982), Volume 27. Number 3, PP 185.196

Kimberly, J R. and Evanisko. M.J. Organizational Innovation The Influence of Individual, Organizational. And Contextual factors (in Hospital Adoption of Technologfcal And Adoinfstrative Innovations". Academy of Managerent Jeurial. (1981), Volume 24. Number 4, pp 689.713

King. P.. "Is The Emphasis of Capteal Budgeting Theory Misplaced?" Journal of Buslness Finance and Acceunclog. TSpring 19/5)" Volume 1. Number 2, pp. 69.82

Kleaselne, C.F. and Maher. MW . Manazement Accounchar Research. (1984). New York. Carland Publishing

Litcrell, E.K. "The High Tech Challenge To Manageaent, Account Ing". - Manseement Acceuncing. (October 1984), Volume 66. Number 4. pp. $33 \cdot 36$

Llevak. I, A and Herner. I. Mulelmatlonels, Advanced Manufaceuring Technologles, and Cahidian Public Pollcy", Busloese guncherby (June 1987), Voluags Number 1. PP 14.19

Lorsh. J.U. and Morse. J J. Oreanlzaslens And Thele Members. (19/6). New York Harper \& Row 
Lowe, I. and Chua, H.F., Organlsatlonal Effectiveness and Management Control", in Lowe, I. and Machin, J.L.J. (eds.), New Perspectives In Mañagement Contrel. (1.983). New York: St. Martin's Press.

Marshall. J.J.. - Innovation Adoption In Industrial Sales Organizations A Fleld Study of The Posc-Adoption Phase In The Case of Telemarketing". Unpublished Dissertaclen. (1985). University of Western Ontario

Martin, R.G.. "Strategic Decisions for Second-Tiered Firms in Changing Environgents". Unpublished Dissertatien. (1984), University of Texas at Austin.

McArthür, J.. "Short-sighted Companies Reflect Society's Value". The Teronto Star. (August 10:1986), Sec. F., P. I

McDonald. I.. "Modern Systems Demand Fresh Look At ROI Concepts", Accountancy. (February 1985), Volume 96, Number 1098, P.p. 136.13 ?

McGourty, B.M., "The Competitive Factary: The First Line of Attack on The Global Marketplace". Speech given te 4th Canadian CAD/CAY Cenference. (June 19, 1985). Toronto. Canada.

McLean I., "Manufacturing: Competitlve Edge Or Corporate Milistone?". The Accountant's Magezine, (May 1986), p. 61 .

Heffe, P. "Automation Audit", Secend Annual International Seminar on Elexible Autemated Assembly, (1985), Toronto, Canada.

Merchant, K.A.. The Deslgn of The Corporate Budgeting Systems: Influences On Managerlal Behavlour And Performance". The Accounting Revlew. (October 1981), Volume LVI, Number 4. PP. 813-829.

Merchant, K.A.. "Influences On Departmental Budgeting: An Empirical Examlnation of A Contingency Model". Accounthe Organizations and Seclety, (1984), Volume 9. Number 3/4: PP. 291-307.

Marchant, K.A. ard Bruns, Jr. Wm.J.. Measurements To Cure Management Myop 1a". Business Horizens. (May/June 1986), Volume 29. Number 3. Pp. $56-64$.

Myers. S.C., "Finance Theory And Financial Strategy". Interfaces. (January-February 1984), Volume 14, Number 1, PP. 126-137.

Natlonal Acadeay of Engineering. Comittee on Technology and International Econoulc and Trade Issues, Autonoblle Panel. The Conpetifly Status of the U.S. Auto Industry. (1982), Washington: Nat tanal Acaderiy Press. 
Nunally, J.C., Esychomecric Theory (Flrst Edifien. (1967). New York McGraw-Hill.

Nunaliy, J.C., Psichomecric Theory (Secend Edition. (1978). New York McG̣rą-Hill.

Onkvisit, S. and Shaw, J.J., An Exasination of The International Product Life Cycle And Its Application Wichin Marketing". Celumbia Journal of Werld Business. (fall 1983). Volume 18. Number 3. PP. 73.79.

Ontarlo Centre for Advanced Manufacturing. Extracts From the Thomeson Lightstone Research Report. (September 18, 1986)

Ontario Ministry of Industry. Trade and Technology. The Marke: For Elexible Automation Equipment in Ontario. (Noveober lag5)

Otley, DI. "Budget Use And Managerial Performance". Leurnal of Accountine Research. (Spring 1978). Volume 16. Number 1. pp $122-149$

Pearson, G. "The Strategic Discount - Protecting New Bustness Projects Against DCF". Long Range Planning. (1986). Volume 10. Number.1. PP. $18-24$

Peter: P. "Reliability A Revlew of Psychometric Basics and Recent Marketing Proctices". Lournal of Markecine Rescarch. "Februaty 1979), Volume XVI, PP 6.17

Pike, RH. "The Capital Budgeting Behaviour And Corporate Characteristics of Capltal-Constralned Firms", Jourual of Busbles: Einance And Accounting. (1983), Volume 10, Number 4. pp 663.669

Pinches, G E, "Myopla, Capstal Budgeting and Decis lon Making". Elnencial Manazenens. (Autumn 1982). Volume 11. Number 3 . PP. $6 \cdot 19$

Port, 0. "Maklng Brawn Work Wlth Brains". Buslness Week. (Apr!l 20). 1987). Pp $56-60$

Pówe11. A. "Turning Costlng On lts Head". Rreducklon Englnest. (Jinr 1986). Voluae 65. Number 6. PP 21.22

Prlorose. P.L. Balley. F A and Leonard, R. The Practical Application of DIscounced Cash Flow To Plint Purchese Uelng An Integrated Sulte of Computer Prograns". Acceunthe And Pusiness Research. (Hincer 1986). Voluse is. Nubber 51. PP 21.31

Pugh, D.S.. Hlckson. D J, Hinlngs, C R and Turner, C : DIaenslons of Organization Structure". Adnhalscrablve Sclence gurcerby. "(Junr

$\because$ 1968), Volume 13. Number 1, PP 65-10s 
Rappaport, A., "Executive Incentives Vs. Corporate Growth", Harvard Busfness Revfew. (July-August 1978), Volune 56, Nubber 4, PP. $81-89$

Reglonal Industrial Expansion. 1983 Report on the Canadian Automotive Indusfry. (1983), Governient of Canada.

Regan. M., "The End of The Line... A Successful Installation", Second Annual Internaclenal seminar on Flextble Aucomated Assembly. (1985), Toronto, Eanada

Reich, R.B. The Next Amerlean Frontier, (1983), New York: Times Books

Rizzi, Joseph $v$. "Captal Budgeting: Linking Financial Analysis To Corporate Strategy", Journal of Business Scrategy, (1984). Volume 4, Number 4, PP. 81-84.

Rogers, E.M., Diffusion of Innevarfons, (1983), New York: The Free Press.

Schroeder, R.G., Qperatiens Manazement: Decisfon Making In The Operactens Function, (1981), New York: McGraw-Hill

Schwarzbach, H.R., "The Impact of Automation On Accounting For. Indirect Costs", Menarement Accounclng, (December 1985), Volime L'vif. Number 6, Pp. 45.50 .

Seed H. "Cost Accounting In The Age of Robotics". Management dccpunting. (October 1984), Volume LXVI. Nymber 4, Pp. $39-43$.

Sheridan, T. "How To Account For Manufacturing". Management Teday, (August 1986), P̈p. $61-74$.

Siegel, S., Nonparametrie Stafistics For The Behavioral Sclences. (1956), New York: McGraw-H111.

Skinner, W., "The Productivicy Paradox". Manazement Revlew. (September 1986), Volume 75. Number 9. PP. 41-45.

Sullivan, Wia.G. "Modela IEs Can Use To Include Strategic, Non-Monetary Factors In Automation Decislons", Industrial-Englneering, (March 1986), Volune 18, Number 3, PP. $42-50$.

Swlerlnga, R.J. and Moncur, R.H., "The Relationshlp Between Menagers' Budget-Oriented Behaviour And Selected Attitude, Position, Size and Performance Heasures", Journal of Accounfine Rerearch (Empleicel Research In Acopunting: Selected Studles). (1972). Volume 10, PP. 194-209.

Tannenbaun, A.S., Concrol in Organkzations, (1968), New York: McGraw HIll. 
Tanner, Ha.R., The 'Manager's Role In Robotization". Managenent. Revlew, (June 1984), Volune 73, Nimber 6, Pp. 15-17.

Thousen, C.T., "Dangers In Discounting". Hansegnent Accounting. (January 1984). Volume LXV, Number 7, PP. 37.39.

Troberg. P.. Accounting And HIgh-Technology": Acceuniting. ereantzatens and Technelese Conference. (Deceaber 10-12,1986). - Masstricht. Netherlands.

Uteche, R. Need Help Justffylng Automation? Here's A Plan That Makes, Sense". Rreduction. (June 1986), Volwe 96. Number 6, Pp .87-88

Ward, J.H., "Partitioning variance and contribution or laportance of a variable: A visit to a graduate seminar". dmertcan Educational Research Journal. (1969). Volume 6. pp. 467.474.

Hilliams, K. and Shultis, R.L. "Roger Solth Steers GM into a High.tech Future". Hanagement Accounting, (Ocţober 1984). Volume 66 . Number 4, PP. $23-29,58$.

Winter, D..."High.Tech's Mid-Life Crisis". Ward's Aute Wordd, (June 1986). Volume 22, Number 6, pp. 33.36:

Woods, M. Pokorny, M. Lintner, V. and Blinkhorn, M, -Appralsing Investment In New Technology. The Approach In Practice". Banagement Acceuncine (U.K.). (October 1985), Volume 63. Number 9. PP. $42 \cdot 43$.

Zaltman; G., Duncan, R. and Holbek, J Innovaclons and Organizaciens. (1973). New York: John Wiley s Sons

Zmud. R.W. . Diffusion of Modern Software Practices: Influence of Cencralization And Formalization:. Manazement Sclence, (December 1982). Volume 28, Number 12, PP. 1421-1431. 